\title{
Modification of the Agenda Setting as a Tool for Political Maneuver in International Politics: Twitter Diplomacy and International Politics of Donald John Trump*
}

\author{
Bulend Aydin Ertekin \\ School of Communication Sciences, Anadolu University, 26470, Eskisehir, Turkey \\ E-mail: baertekin@anadolu.edu.tr
}

\begin{abstract}
From the past to the present-day studies on political communication have focused on the agenda setting influenced by the media tools being constantly evolving due to technological opportunities and their areas of use. In changing and developing processes, the agenda setting is determined not only by the media but also by public and political factors. As a result, each of the media, public and political agendas defines or modifies the agenda as factors and actors. While the power of agenda setting was left unilaterally to the media in the past, it is seen that politicians tend to take more initiative under this power ownership. On the other hand, politicians who see the power of setting the agenda in political communication, in addition to influencing the public and politics through the media, also realize the role of influencing the public through politics.

New media, renewed every day since the beginning of the 21 st century, have also made it easier for politicians to access the public in this race of power supremacy. The use of Twitter for political communication, which provides access to many more viewers and followers among the tools of the new media over the internet much more than classical media, has made Twitter important. The use of Twitter as a means of diplomacy and international politics by US President Trump has made it more popular among the new media.

In this study, as emphasized the importance of agenda setting, Trump's ability to engage in diplomacy and international politics through Twitter and its influence on international markets was examined. In addition to the literature research, the study examines the tweets that Trump publishes periodically and gives examples of the issues that affect the media agenda. As a result, it is seen that Trump is effective in determining the political agenda via Twitter and pioneering information about Trump's foreign policy and diplomacy have been caught on the international agenda through his tweets.
\end{abstract}

Keywords: Agenda Settings, Twitter, Trump, Political Communication, Diplomacy.

DOI: $10.7176 / \mathrm{JSTR} / 5-8-12$

\section{Uluslararası Siyasette Siyasi Manevra Aracı Olarak Gündem Değiştirme: Donald John Trump'ın Twitter Diplomasisi ve Uluslararası Siyaseti}

\begin{abstract}
Özet:
Geçmişten günümüze medya araçlarının kademeli olarak değişen teknolojik imkân ve kullanım alanlarından etkilenen gündem belirlemenin üzerinde durulması siyasal iletişim çalışmalarının odak noktası olmuştur. Değişen ve gelişen süreçlerde, gündem sadece medya yolu ile değil aynı zamanda, kamu ve siyasi faktörlerle de belirlenmektedir. Buna göre, medya, kamu ve siyasi gündemlerin her birisi hem birer faktör hem de birer aktör olarak gündemi belirlemekte veya değiştirmektedirler. Gündem belirleme gücü geçmişte sadece tek taraflı olarak medyaya bırakılırken, günümüzde bu güç sahipliğinde, siyasilerin de daha çok inisiyatif almaya eğilimli oldukları görülmektedir. Siyasal iletişimde gündem belirlemenin gücünü gören siyasiler ise, medya yolu ile kamuyu ve siyaseti etkilemenin dışında, siyaset yolu ile de kamuoyunu etkileyebilme rolünü gerçekleştirmektedirler.
\end{abstract}

21.yüzyılın başlangıcından beri her gün yenilenen yeni medya araçları, bu güç üstünlüğü yarışında 
siyasilerin kamuya erişim imkânlarını ayrıca kolaylaştırmıştır. Yeni medyanın araçları arasında internet üzerinden klasik medya araçlarından çok daha fazla izleyici ve takipçiye ulaşım imkânı veren Twitter'ın siyasal iletişim için kullanımı, Twitter'ı ayrıca önemli hale getirmiştir. Twitter’’ ABD başkanı Trump'ın bir diplomasi ve uluslararası siyaset aracı olarak kullanması ise onu yeni medya araçları arasında daha popüler hale getirmiştir.

Bu çalışmada, gündem belirlemenin önemi vurgulandığı gibi, Trump'ın Twitter kanalı ile diplomasi ve uluslararası siyaset yapması, uluslararası piyasaları etkileme gücü incelenmiştir. Çalışmada literatür araştırmasının yanı sıra, Trump'ın belli periyotlar içinde yayınladığı tweetler incelenmiş ve o tweetler ile medya gündemini etkileyen konulara ilişkin örnekler verilmiştir. Sonuçta, örneklerden Trump'ın Twitter aracı ile siyasi gündemi belirlemede etkili olduğu ve Trump dış politikasına ve diplomasisine ilişskin öncü bilgilerinin bu tweetler aracı ile uluslararası gündemde yer aldığı görülmektedir.

Anahtar Kelimeler: Gündem belirleme, Twitter, Trump, siyasal iletişim, diplomasi.

\section{Giriş}

Kitle İletişim ve Medya alanında sayısız teori bulunmasına ve bu teorilerin günün gereklerine göre yenilenmesine rağmen, bu teoriler arasında yer alan "Gündem Belirleme Teorisi” (Agenda Setting Theory) siyasetçilerin oluşturduğu gündemleri kamuoyu denkleminde inceleme açısından güncelliğini bazı karşı eleştirilere rağmen halen korumaktadır. Belki de bu teorinin sürekliliği ve devamlılığı bir kavram olarak siyasilere, siyasal partilere ve liderlere bağlı olarak ömrünü sürdürecektir. Ancak, alg1 ve kamuoyu yaratmada sayısı teorilerden biri olan ve gündemin ölçülmesinde yararlanılan "Gündem Belirleme Teorisi" 1922'de Lippmann tarafindan ortaya atılan "medya, görüntüleri halka sunma gücüne sahiptir" mottosundan sonra 1968'den itibaren McCombs ve Shams tarafından Amerikan Başkanlık seçim kampanyalarına ilişkin çalışmalarıyla yeni bir görünüm kazanan [1] haber medyasının kamuoyu gündemini belirlediğine[2] ilişkin temel düşüncesinin aksine günümüzde artık liderlerin de sosyal medya uygulamaları aracılığıyla gündemi belirlediği realitesi ile karşı karşıya bulunulmaktadır. Liderlerin bunu yaparken, verdikleri demeçler ile klasik medya ve yeni medya araçlarını siyasi manevra aracı olarak kullanıp, kendilerini siyasi sahnede odak noktasına oturtup, alg1 ve kamuoyu oluşturma ve mevcut gündem maddelerini belli bir süre için değiştirme mekanizmasında kullandıkları görülmektedir. Artık bir bakıma, uluslararası sistemde, özellikle bir boşluk doğduğunda veya yeni bir haber oluşturmak için haber medyasının dışında uluslararası liderler de spontane gündem oluşturmaktadırlar. Ancak kısa süreli bu gündem değişiklikleri, önem ve etkisini yitirdiğinde yeni gündem değişikliklerine ihtiyaç duyulmaktadır. Bir döngü içinde, bu siyasi manevralar tekrar veya tekrarın tekrarı veya eskinin yeni bir gündem maddesi ikamesiyle güncellenmesi yolu ile akılcı yapıldığı takdirde siyasi liderler lehine kamuoyunu etkileyebilmekte ve kendilerinin de gündem de kalmasına katkı sağlayabilmektedir. (Şekil 1) [3]

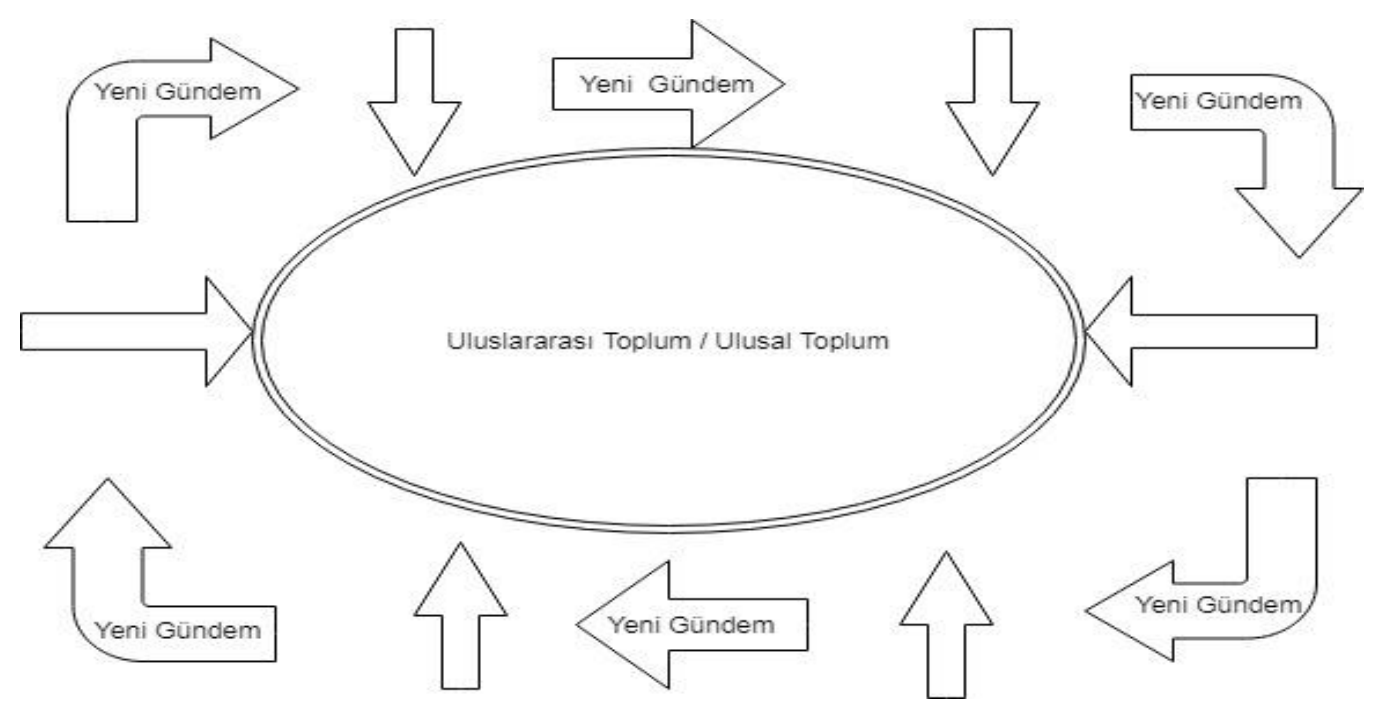

Şekil 1. Yeni Gündem Döngüsü ve Uluslararası ve Ulusal Toplumun Şekillendirilmesi 
Bu döngüyü, işletme biliminde sıkça kullanılan PUKÖ[4] (planla, uygula, kontrol et, önlem al) döngüsüne de benzetebiliriz. PUKÖ'dan esinlenen modelde, medya, kamu ve siyaset gündemlerinde kamuoyunun iradesinde dışında kamuoyu örgütlü bir gündem yapısı ile de karşı karşıya kalabilir. (Şekil 2) Bu döngü simülasyonunda, planlanmış, uygulamaya konmuş, kontrol edilmiş ve önlemi alınmış (etki alanı ve sınırı belirlenmiş) yeni gündemler birbirini takip eder derecesinde sıralanmaktadır.

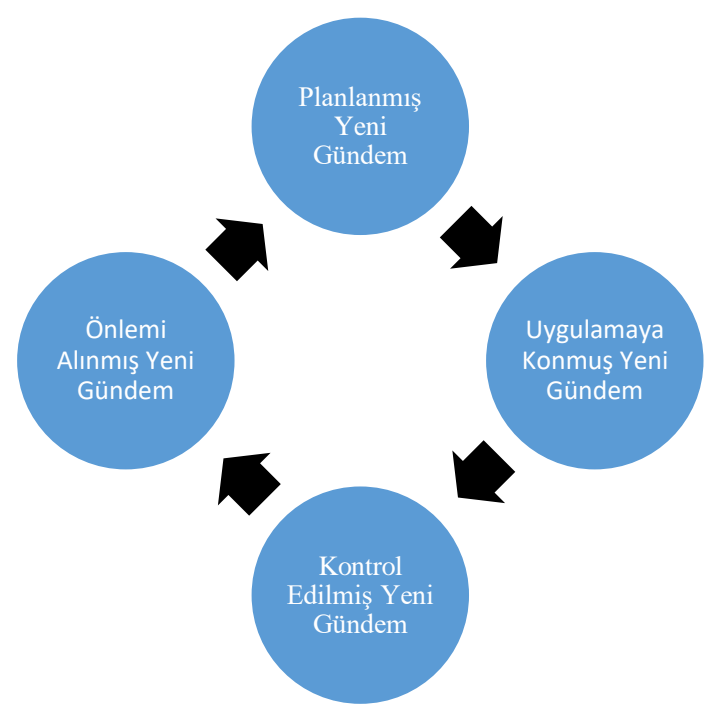

Şekil 2. Gündem Oluşumunda PUKÖ Döngüsü [5]

Kimi zamanda ise bu siyasi manevralar, lehte bir kamuoyu oluşturma ihtiyacından öte, liderlere serbest hareket edebilecekleri bir boşluk yaratmakta, alan açmakta ve siyasi hedefleri için zaman kazandırmakdır. Liderler kendi gündemlerini yaratıp, yeni bir gündem oluşturmayı başarıyorlar ise, bu gündemin kamuoyuna ulaşması da yine klasik, eski ve yeni medya araçları vasıtasıyla olmaktadır. Bu durum, iki oyuncu ile oynanan bir spor aktivitesine benzetilebilir. Oyunculardan birinin performansını göstermek için diğerine ihtiyacı olduğu gibi, birinin üstünlüğü diğerinin var olması ile bağlantılıdır. Bununla birlikte, bu ikili ilişki içinde, üçüncü aktör olan ve seyirci konumunda olan medya takipçilerini de unutmamak gerekmektedir. [6] Bu bağlantıda yeni medya araçları, liderlerin siyasi manevra sahasını oluşturmada önceliği teşkil etmektedir. Günümüzde ise, her gün piyasaya giren farklı uygulamalarıyla yeni medya araçları içinde internet ve web tabanlı sosyal ve iletişim uygulamaları liderlerin gözde olan siyasi iletişim araçları içinde yer almaktadır. Bu türden uygulamaların içinde 2006 Mart ayında kurulmuş olan Twitter uygulaması, bu uygulamayı siyasi iletişim aracı olarak kullanan siyasilerin bir "ilan ve bildiri panosu”na” dönüşmüştür. Twitter uygulamasının kullanımı, vatandaşların düşüncelerini ifade etmenin dişında, siyasi liderler için bir gündem yaratma alanı görünümü kazanmıştır. Özellikle daha önceki meslektaşlarına göre hükümet kararlarından önce kendi kişisel karar ve yorumlarını ulusal ve uluslararası kamuoyu ile paylaşan Donald John Trump bir anda uluslararası siyasi dengeleri etkilediği gibi, uluslararası sermaye hareketlerinde borsalarda "boom and bust cycles" denilen yükseliş ve inişlere sebebiyet vermektedir. Bu durum spekülatif kazanç ve zararlara da yol açmakta ve uluslararası döviz kurlarını çoğunlukla olumsuz yönde etkileyebilmektedir.

Özellikle, Trump'ın, sınır güvenliği, petrol fiyatları, uluslararası enerji ve güvenlik kapsamında sürdürülen İran nükleer müzakereleri ve iklim değişikliği ile ilgi Paris Şartı ve ticari ilişkiler kapsamında Trans-Pasifik antlaşması gibi taahhüt ettiği uluslararası anlaşmalardan geri çekilmesine yönelik konularda ve İran, Avrupa Birliği, Rusya, Çin veya Orta-Doğu ülkeleri ile ilgili Twitter üzerinden paylaştığı aldığı veya çoğunlukla kısa bir süre sonra alacağını duyurduğu kararlar, sert yorum ve eleştiriler uluslararası istikrarı ve güvenliği farklı yönlerden olumlu veya olumsuz yönde etkileyebilmektedir.

Doğal olarak, bu "Twitter-etkisi” Trump için iç politika alanında bir siyasi alan açma stratejisi olarak kendi siyasi kredibilitesine olumlu katkı yapmayı gütmektedir. Trump' ’n Twitter siyaseti kendi siyasi yaşam alanı için gerekli olduğu gibi, Twitter üzerinden paylaştığı ABD ulusal çıkarlarının yararına olduğunu beyan ettiği tweetler aynı zamanda kendi siyasi destekçisi olan Cumhuriyetçi parti seçmenlerinin de desteğini almayı hedeflemektedir. Twitter'ın canlı yayınlanan bir televizyon röportajındaki gibi lider üzerinde baskı ve stres 
yaratmaması, izleyici tarafından konuşmacının hazır cevaplılık potansiyelinin ölçülememesi, kullanıcı konumunda olan liderin kendi cevabını vermesi, kendi sorusunu sorması, kendi kararını vermesi ve kendi eleştirisini istediği şekilde yapması lidere bağımsız siyasi manevra alanı kazandırmaktadır. Bir anlamda Twitter, Twitter kullanıcısı lidere üstünlük veren psikolojik bir araca(silaha) dönüşmektedir.

Twitter kullanıcı sayısı mükerrer, sahte ve sanal takipçilerin de "takip edenler" arasında yer almasına rağmen, $P R$ açısından kullanıcı lehinde bir kredibilite sağlamaktadır. Bir bakıma "çok takipçi çok popülarite” algısı yaratmaktadır. Oysa gerçek kişi ve gerçek takipçi sayısının gerçek oranı, dünyaca ünlü starlar ile karşılaştırıldığında az olsa da, bir bakıma yüzbinlerce, birkaç milyon takipçi olan Twitter kullanıcısı liderlerin Twitter üzerinden yayınladığı tweet'lerin 24 saat veya 7 gün içinde "beğenilme ("like" alması)" ve paylaşılma sayıları ile bir orantı kurulması ile genel bir fikir elde edilebilir. Ancak, tüm sanal medya takipçilerinin her mesajı veya tweet'i beğenmeden veya paylaşmadan da okuması da söz konusu olacağı gibi, birden fazla hesabı olma ihtimali de olan takipçilerin reel sayıları Twitter'ı siyasi pano olarak kullanan liderler için önem ihtiva edebilir.

$\mathrm{Bu}$ çerçeve içinde, bu çalışmanın amacı siyasi gündem yaratmada lider ve yeni haber medyası uygulaması olan Twitter'ın kamuoyu yaratma denklemine vurgu yapmak olacaktır. Ancak hemen her gün belli veya farklı konularda tweet üstüne tweet yayınlayan Trump'ın tweetlerindeki tüm konuların ele alınmasının bu çalışmanın sınırları içinde imkânsız olması nedeniyle, konuya destek amaçlı olarak birkaç tweet konu örneği üzerinde durulmaktadır. Bu çalışma kapsamında ele alınan tweetler; uluslararası piyasalar, ticaret savaşı ve petrol fiyatlarına ilişkin 2 Mart 2018, 9 Haziran 2018, 20 Nisan 2018, 30 Haziran 2018, 20 Temmuz 2018, 20 Eylül 2018, 25 Şubat 2019, 22 Nisan 2019 tarihli tweetler ile ABD büyükelçiliğinin Kudüs’e taşınmasına ilişkin 6 Aralık 2017, 14 Mayıs 2018 ve Golan'ın ilhakına ilişkin 21 Mart 2019 ve 25 Mart 2019 tarihli destek tweetleri incelenmiştir. Trump'ın Twitter yolu ile piyasaları etkilediğine ilişkin haberler Google arama motoru ile taranarak tablolaştırılmıştır. Çalışma kapsamında ayrıca, 21 Mart 2016 ve 18 Mart 2019 tarihleri, Şubat 2017 ve Şubat 2019 arası dönem ile 1-8 Mart 2018 tarihleri arasındaki ortalama piyasa endeksleri incelenmiştir.

\section{Geçmişten Günümüze Gündem Belirleme Teorisi: Kamuoyu, pseudo-çevre ve algı oluşturma ile olan ilişkisi}

Gündem belirleme teorisi ile ilgili araştırmalar yeni olmayıp, Batı literatüründe çok eski yıllardan beri ve ülkemizde de özellikle 80 ve 90'lı yıllardan itibaren başlayan ilgi alanının araştırmacılar sayesinde 2000'li yıllardan itibaren artarak yoğunluk kazandığını görmekteyiz. Bernard Cohen’in kalıplaşan “...[b]asın, insanlara ne düşüneceklerini söylemede çoğu zaman başarılı olmayabilir, ancak okuyucularına ne hakkında düşüneceklerini söylemede şaşırtıcı derecede başarılı..."[7] olabilir sözünün vurgu yaptığ1 gibi, gündem belirleme teorisi temelde ilgili kişi veya konu hakkında gündem oluşturma ve bu gündeme dayalı olarak lehte veya aleyhte bir kamuoyu oluşturma rolünü yerine getirmede kullanılan bir araçtır.

Bu bağlamda gündem oluşturma teorisinin, klasik ve yeni medya çerçevesinde fonksiyonel unsurları; hedef gündem konusu, gündemin içeriği, hedef kitle ve hedef kitleden oluşturulacak kamuoyu gücüdür. Bir bakıma bu unsurlar birbirlerini tamamlamaktadır. İçeriği belli ve açık olmayan bir konu gündem olamayacağı gibi, gündem olarak ortaya atılan konu içeriğinden yoksun bir gündemin de kamuoyu oluşturma gücü yoktur.[8] Doğal olarak gündem belirleme teorisinin ana ekseni, klasik ve yeni medya kitle iletişim araçları vasıtasıyla medyanın gündemi belirlediği ve bu teorinin kurucuları ve araştırmacıları tarafından ileri sürüldüğü gibi, aynı medyanın gündem oluşturma, kamuoyu yaratma ve algı şekillendirme gücüne sahip olduğudur.[9]

Buna karşın, mevcut aksi düşüncelere yine McCombs'un yer verdiği görülmektedir. Medyanın gündem belirlediğini reddedenler ise "[b]iz sadece dünyada ne olduğuna dair haberlerin muhabirliğini yapıyoruz" derken [b]azı gazetecilerin, kamu üzerinde herhangi bir gündem belirleme etkisinin olduğunu kabul etmediklerini söylemektedirler. Aynı benzer varsayımdan hareket ederek, bazı gündem belirleme fikrine eleştiri getirenler kamu ve medyanın benzer şekilde kendilerini çevreleyen ortama cevap verdiklerini iddia etmektedirler ..."'[10] Oysa diğer taraftan Lippmann'a atıf yapan McCombs, Lippmann'ın daha 1920'lerde “haber medyası rolünün dış dünya ile kafamızdaki imajlar arasında bir köprü" [11] görevi gördüğüne ilişkin "pseudo-çevre" [12] kavramına da vurgu yapmaktadır.

Lippmann'a göre, "Pseudo-çevre veya kafalarımızın içindeki imajlar"[13] zihinlerimizde var olan bir dünyanın görünümüdür.[14] Bu görünüm ise, gerçek karşısında eksik ve yanlıştır, çünkü kamuoyu olarak gösterdiğimiz davranışlar gerçek çevreye değil ama pseudo-çevreye verilen bir cevap niteliğindedir.[15] Bu noktada, medyanın insanların zihinlerindeki imajları şekillendirmede ne kadar güçlü olduğu vurgulanmaktadır, çünkü “...[s]iyasi olarak ele aldığımız dünya, ona erişilmesinden, gözden ve zihinden uzaktır... ”[16] Bu durumda ise, bu siyasi dünyaya yönelik algı şekillenmesi ve ona yönelik davranışlar ve 
düşüncelerde, medya da temel rol oynamaktadır. Geçmişte, MacCombs'un değerlendirmesine göre, “....Lippmann’ın döneminde kamu işlerine ilişkin bilgilerin temel kaynağı günlük gazeteler iken, bugün, çok çeşitli yaygın ve geniş iletişim kanallarımız mevcut bulunmaktadır. Fakat ana nokta değişmeden aynı kalmaktadır. Halk gündemi ile ilgili kayglların neredeyse tamamı için vatandaşlar, bu olaylar ve durumlar hakkında gazeteci röportajları ile yapılandırılmış bir gerçek olan, bir ikinci gerçeklik ile karşı karşıya kalmaktadırlar...' [17] Demek ki sadece medya gündemi değil halk gündeminde Lippmann'ın 1920'lerde vurguladığı bu pseudo-çevre yani “kafalarımızdaki (zihinlerimizdeki) imajlar(resimler)” algılarımız ve dolayısıyla, düşünce ve davranışlarımız üzerinde etkin rol oynayabilmektedir.

Lippmann'ın bu tanımından etkilen Akira Fujitake ise, pseudo-çevreyi iki şekilde tanımlamaktadır. Birincisi, geniş anlamdaki tanıma göre, pseudo-çevre, zihinlerimizdeki öznel bir imaj iken, medyanın gerçeklik betimlemesini tarif etmek için kullandığı dar anlamda ise pseudo-çevrenin, medya personeli tarafindan oluşturulmuş bir kurgu olan, gerçek bir çevrenin(ortamın) temsil edilmesinden başka bir şey olmadı̆̆ını ifade etmektedir. [18] O halde bir tarafta haber medyasının gündem etkisinin öneminden[19] bahsederken gündem oluşturmanın yanında Lippmann'ın tabiriyle kamuoyunun kafalarındaki imajları şekillendiren ve bir algı yönlendirme gücüne sahip olan aynı medya, nasıl ve hangi ölçülerde bir IV. Kuvvet olarak gazeteci ve medya eleştirmeni olan William L.Rivers'ın 1980'li yıllarda söylediği ve ünlü Watergate skandalında olduğu gibi "gölge hükümet”[20] olabilme gücüne sahip olabilecektir? Yine aynı medya hangi kapasite içinde, bir zamanlar Amerika Birleşik Devletleri’nde 1954-1976 yıllarında önem arz eden bir konu olan sivil haklar konusunda [21] savunucu olabilecektir? Tüm bu eleştirel sorular ile "gündem oluşturma gücünü belirleyen medya" tanımlaması ise medya meslek etiği boyutundan bakıldığında bir ikilem gibi görülmektedir. Bu ikilemin ortaya koyduğu diğer bir soru ise, "eşik bekçileri" veya "watch dog" sıfatıyla çağrılan medyanın kamu adına kamu içerikli bir medya gündemi mi oluşturduğu yoksa haber kaynaklarından aldığı haberler doğrultusunda siyasi erk adına siyasi içerikli bir medya gündemini kamuya aktardığı mı? şeklinde sorgulanabilir. Bu sorunun cevabı yine 1920'lerde Lippmann'ın ortaya attığı kafamızdaki imajların şekillendirilmesine vurgu yapan düşünceye paralel olarak yine aynı dönemlerde medya eli ile kültürün oluşturulmasına ve dolayısıyla kültür endüstrisini temsil eden bir medya yapılanmasına karşı gelen Frankfurt Okulu’nun görüşüne göre evettir. Çünkü “...[k]ültür endüstrisinin tek amacının kâr elde ederek üretim olması nedeniyle, kendilerince de kültür endüstrisi kültür karşıtıdır. Bu endüstri tarafından hedeflenen kârlılık hedefi üretiminin kültür yönünü yok edecektir. Öyle ise, üretilenlerin artık kültür ile alakası yoktur. Aksine onlar, gerçek kültüre muhalif olarak elitlerin kültürüne aittirler. ”[22]

\section{Klasik Medya Haber Gündeminin Oluşumunda Etkin Olan Araç ve Aktörler}

Amerika Birleşik Devletleri'nde gündem belirleme çalışmasının öncüleri, daha önce 1920'lerden gelen kesin hüküm ile haber medyasının zihinlerdeki imajı teşkil eden gündem oluşturduğu fikrine sahip olmalarına rağmen 1990'lı yıllarda “Medya gündemini kimin belirlediği”" [23] sorusunu sormaktadırlar. Buna göre, "[b]aşkan ve eyalet hükümetlerinin kurumlarl gibi kaynaklar, günlük haberlerin tonunu ayarlama da önemlidirler. Fakat bu kaynakların sadece az sayıdaki gazeteci ile doğrudan temasları bulunmaktadır. Yerel gazete veya yerel televizyon istasyonlarının haber gündemlerinin, The New York Times gibi seçkin gazetelerdeki hikâyelerin takdimi ve haber servisleri tarafindan yerel haber bültenlerine sunulan günlük haber diyetlerinden etkilenme olasılı̆̆l çok daha yüksektir..."'[24] sonucuna ulaşılmıştır. Örneğin, gündemleri belirleyen haberlerin kaynaklarının haber servisleri olduğuna yönelik olarak, 52 Ohio gazete ve televizyon çalışanı ile eşik bekçiliğinin öneminin yaygınlaştırılmasına yönelik yapılan bir araştırmada, medya çalışanlarının düzenli olarak yaptıkları gündelik görevlerinde, haber ajanslarından gelen haberler arasından seçim yaptıkları yönünde bir sonuca varılmıştır.[25] Bu bir bakıma, 1990'lı yıllarda haber medyasının gündemini oluşturmada etkin gücü olan haber servislerinin bugün dahi göreceli de olsa güçlerini devam ettirdiği söylenebilir.

Diğer taraftan, medya haber gündeminin kaynakları ne olursa olsun, Turk'e göre, “... [h]alkın medya kitle iletişim araçlart vasitasıyla gördüğü dünya, gerçeğin ne aynadaki aksi ne de olayların, mahallerin ve sorunların gerçek fotoğrafi değildir. Medyanın haber penceresi, onun yerine, medyanın kendi inşa ettiği gerçeğin bir yansımasıdır. Medya, bir arka planın ve gündemin pseudo-çevresi olan kendi yarattı̆̆ gerçeklik muhasebesinde az bir sayıda konuların(objects) ve elekten geçilmiş nitelikteki unsurların manşet yapılmasına katkı sağlar. Bu nedenle, medyada temsil edilen enformasyon ve bu enformasyona medyanın verdiği önem, medya gündeminde neyin ne kadar önemli olduğu şeklinde yorumlanabilir. " [26] Bununla beraber, medyanın kendisinin sahip olduğu bu gündem yaratma gücünün medya dışındaki aktörlerden bağımsız olduğunu söylemeyiz. Yine Oscar H.Gandy’e atıf yapan Turk'e göre, haberleri gazeteci ve kaynağ1 arasındaki etkileşim yaratmaktadır.[27] 
Bu etkileşim ve ikili ilişki[28] içinde, medya, geniş bir çerçeve içinde kamuoyunun sahip olduğu önceliklere önem verdiği gibi kendinin önem verdiği öncelikleri de yoğun bir şekilde etkileyebilir.[29] Gerçekte ise, kamuoyunun etkilenme sürecinde, bu pseudo-çevre gölgesi altında, medya haber kalıpları ile kamu gündeminin ilgi ve alaka duyduğu konuların ele alınışında, medya gündeminin belirlediği en belirgin olan kamu sorunlarının, kamu gündeminin en önemli kamu sorunlarına etki yapabileceği durumudur. [30] Aynı şekilde, zihinlerdeki imajlarının oluşmasında, medya gündemi ve kamu gündemi ilişkisi incelendiğinde, klasik yapıdaki gündem belirleme sürecinde konuların ön plana çıtı̆̆ı belirgin bir hal ortaya çıkarken, niteliklerin daha etkili olduğu ikinci düzeyde ise nitelikleri daha belirgin hale getirerek ön plana çıkaran bir oluşum söz konusudur.[31]

Gündemlerin diğer bir sınıflandırmasında, McCombs bu sınıflandırmayı üçe ayırmaktadır. Medya ve Kamu gündem sınıflamasının yanı sıra diğer kategoriyi "Diğer Gündemler" adı altında tanımlayarak, bu kategoriye bağlı alt alanları da, örgütler, baskı grupları, halkla ilişkiler ve siyasi kampanyalar adıyla tanımlamaktadır. [32] Soroka ise, Şekil 3'te görüldüğü gibi, gündem belirlemeyi üç temel sınıflandırma ile göstermektedir. Bunlar, medya gündemi, kamu gündemi ve siyasi gündemdir. Bu üç gündem birbirlerini dereceli olarak etkilemektedir.[33]

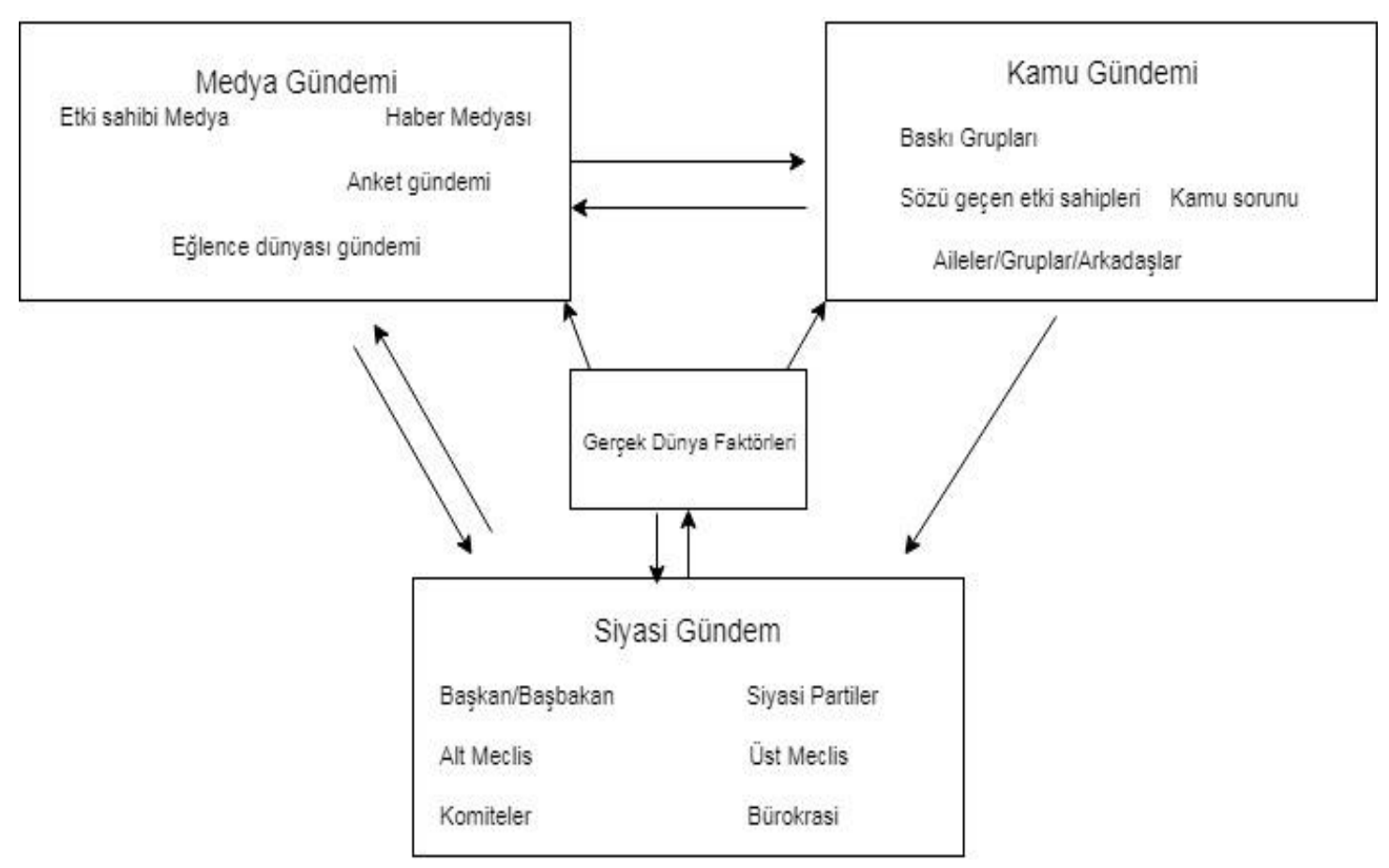

Şekil 3. Soroka'nın Gündem Belirleme Sürecine İlişkin Genişletilmiş Modelleme Simülasyonu

Kaynak :Soroka, Stuart N . (2002) "Issue Attibutes and Agenda-Setting by Media, the Public, and Policymakers in Canada", International Journal of Public Opinion Rsearch, volume 14, Issue 3, 1 September 2002, p.270 (264-285), https://doi.org/10.1093/ijpor/14.3.264, https://goo.gl/evN9en erişim tarihi :25 Ocak 2019; Ayrıca bkz. Yüksel, Erkan (2001). Medyanın Gündem Belirleme Gücü, Çizgi Kitapevi, Konya, s.52

Soroka'dan daha önce de Everett ve Dearing gündem belirleme süreçlerini medya gündemi, kamu gündemi ve siyasi gündem olarak tanımlamaktadır. [34] Everett ve Dearing’e göre, “.... Illk araştırma geleneğini medya gündem belirleme olarak adlandırmaktayı, çünkü kitle iletişim araçları haberleri gündemi ana bağıml değişkeni temsil etmektedir. İkinci araştırma geleneğini kamusal gündem belirleme olarak adlandırmaktayız, çünkü ana bağımlı değişken kamusal gündemdeki konuların içeriği ve sırasını oluşturmaktadır. Üçüncü araştırma geleneği politikasına gündem belirleme adını vermekteyiz, çünkü bu seçkin geleneğin bir klsmı, hem medya gündemine hem de kamu gündemine bir cevap olarak politika konusuna duyulan ilgi ile ilintilidir..." [35] Bu tanımlamadan hareket eden, Everett ve Dearing Gündem Belirleme Sürecini Şekil 3'te olduğu gibi üç temel sınıflandırmaya ayırarak şematize ederken[36], diğer taraftan ise gündem belirleme teorisini eleştiren Ivengar ve Kinder (1987)'in saptamalarına yer vermektedir. Ivengar ve Kinder'ın “.... " [b]irkaç önemli istisna dışında, gündem belirleme araştırması teorik olarak naif, metodolojik olarak ilkel, hem karlşık hem de kafa karıştırıcı olmuştur .... Gündem belirleme uygun bir 
metafor olabilir, ancak teori değildir..."[37] şeklindeki analizi de gündem belirleme teorisinin araştırmalarda bir teoriden öte bir yöntem olabileceği tezini ileri sürse de, alanda yapılan sayısız çalışma gündem belirleme ile siyasal iletişimin ayrılmaz bir ilişki içinde olduğunu ortaya koymaktadır.

Şekil 4'te yer alan Everett ve Dearing ortaya koydukları simülasyonda açık bir şekilde görüldüğü gibi, mevcut ve etkin medya çalışanlarının ve etki gücü yüksek haber ve olayların, medya gündemini, medya gündeminin sırasıyla kamu gündemini, kamu gündeminin siyasi gündemi oluşturma süreci yaşanmaktadır. $\mathrm{Bu}$ şema içinde, Everett ve Dearing medya gündeminin doğrudan siyasi gündemi veya siyasi gündemin medya gündemini etkilediğini göstermektedir. Diğer taraftan, buna paralel olarak, seçkinlerin ve deneyim sahibi kişilerin ikili ilişkileri ya da bir gündem konusunun veya olayının bu üç ana bileşenin her birisini tek tek ya da bir bütün olarak etkileyebildiğini tanımlamaktadır. Ancak gündem süreçlerini ve gündemi belirleyen etkin konumdaki eşik bekçilerini ve bekçi köpeklerinin (watchdog)[38] de nasıl denetleneceği ayrıca sorgulanmaktadır.[39] Bu durum, bir taraftan gazeteci olan eşik bekçilerinin meslek etiği açısından deontolojinin ön plana çıkmasını gerektirmektedir. Ancak, Pritchard ve Sauvageau'a göre, "[bir] çok gazeteci deontoloji kodlarından hoşlanmamaktadırlar... Deontoloji kodlarının muhalifleri, oto-sansürün olmadığı durumlarda gazeteciler tarafından çok aşırı bir düzeyde dikkat gösterilmesinden çekinmektedirler. Genel olarak ifade edilirse, onların tasaları, ne kadar fazla bir çerçeve içine alınılırsa, o ölçüde özgürlük alanının da sınırlandığına ilişkin görüşü paylaşanların söylevlerine katılmalarıdır...”[40] Eşik bekçileri için diğer bir sorun ise küresel rekabet sorunudur. Haber üretmek pahalıya mal olabildiği gibi, günümüzde internet üzerinden bir sürü haber ve dedikodu niteliğindeki haberlere ücretsiz erişilmekte ve bir çaba sonucu üretilen haber içerikleri ve haber fotoğrafları sosyal medya yolu ile yayınlanabilmektedir.[41] Bunun yanı sıra ise özellikle Amerika Birleşik Devletleri’nde yaklaşık 1400 günlük gazetenin yarısından çoğu reklam gelirlerini kaybetmiştir. Örneğin, bu oran 2003 yılında 46 milyara ve 2013 yılında ise 20,7 milyar dolara düşmüştür. Yine aynı şekilde popüler olan dijital alternatifler dolayısıyla otomobil, iş ve ev ilanları gibi seri ilanlardan gazetelerin elde ettikleri gelirler 2003 yılında 15 milyar dolardan 2013 yılında 4 milyar dolara kadar düşmüştür.[42]

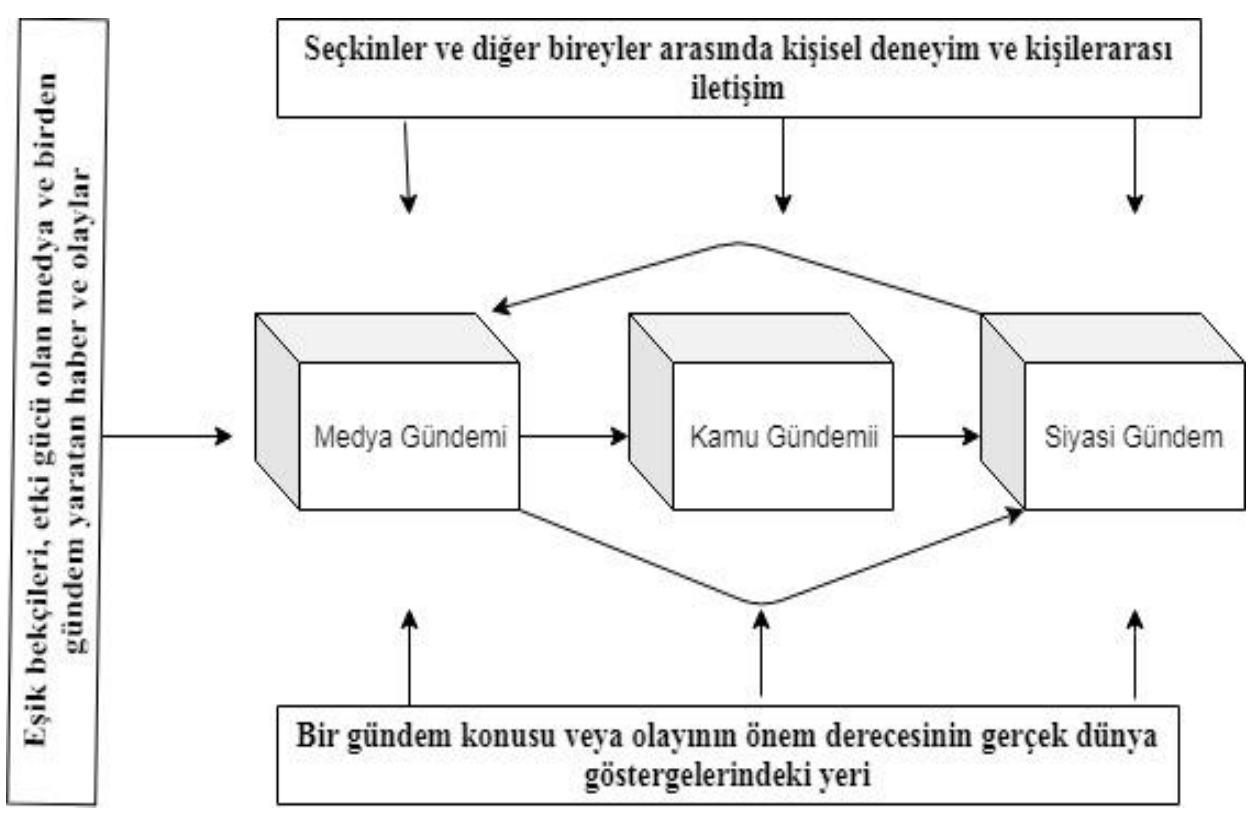

Şekil 4. Gündem Belirleme Sürecinin Üç Ana Bileşeni: Medya Gündemi, Kamu Gündemi ve Siyasi Gündem

Kaynak : Everett M.Rogers-.Dearing, James W. (1988). “Agenda-Setting Research: Where has It Been, Where Is It Going?”, Communication Yearbook 11, January 1988, s.557 (555-594), https://goo.gl/4rzp3J, erişim tarihi : 29 Ocak 2019; Ayrıca bkz. Yüksel,Erkan. (2001) Medyanın Gündem Belirleme Gücü, Çizgi Kitapevi, Konya, s.29

Everett ve Dearing'in bu gündem belirleme sürecini değerlendiren Yüksel (2001) ana bileşenlerin etki sürecinin analizinde şu değerlendirmeye yer vermektedir: 
"Süreç içerisinde haber değerleri ya da izleyenlerin tercihleriyle fark edilen medya gündeminin, kamu gündemini ve onun da siyasal ya da bask gruplarının belirlediği siyasal gündemi etkilediği ve yine aynı şekilde medya gündeminin siyasal gündemden, siyasal gündemin de medya gündeminden etkilendiği ifade edilmektedir. Buna göre bu gündemlerin her birinin diğerlerini etkilemeye uygun konumda ve etkileşimde olduğu görülebilir. Ancak bu arada söz konusu süreci etkileyen bir takım faktörlerden de söz edilmektedir. Medya gündeminin haber eleyiciler ve ani gelişen olaylar gibi kimi unsurlardan etkilendiği belirtilirken, sürecin tümüne yönelik olarak kişisel deneyim ve seçkinler ile diğer bireyler arasındaki bireyler arası iletişim ve gerçek yaşam göstergeleri müdahaleci unsurlar olarak siralanmıştır. ” [43]

Tüm haber gündeminin süreçlerinin birbirine bağlı veya birbirinden bağımsız olarak etkileyen araçları veya aktörleri eşik bekçileri, medya ve siyasi elitler, kamu kurumları ve ikili ilişkiler çerçevesinde imtiyaz sahibi veya kaynak bireyler olarak sıralarken, doğal olarak klasik medya içinde önemi olan ve yeni medya içinde de kendini sosyal medya ile güncelleyerek etkin olan uluslararası yayıncılıkta rollerine devam eden televizyon kanallarını da unutmamak gerekir.

McPhail' in Amerika Birleşik Devletleri'nden bahsederken, “Amerika Birleşik Devletleri'nde haber toplama açık ve belirgin şekilde $A B C, C B S, F O X, N B C$ ve MSNBC ve FOX News üzerinden olmaktadır. Ek olarak, şu anda üç ABD haber[44] kanalı var: CNN, MSNBC ve FOX News. [Bunun yanı sira,] küresel boyutta haber yayın yapan iki küresel haber ă̆ı vardır: CNN ve BBC Dünya Televizyon Servisi. ’[45]

Günümüzde ise internet üzerinden yayınlanan değişik bilgilere göre; bu televizyon kanalları içinde, BBC World News, Fox News, CNN, Sky News, MSNBC, Al Jazeera, Euronews, Al Arabiya, Geo News, NDTV India, RT[46] bulunmaktadır. Bu kanallara her gün popülerliğini arttıran TRT World ve uzun yıllardan beri yayın yapmakta olan DW ve France24 kanallarını da ilave edebiliriz. Ayrıca, dünyada ekonomik gelişimi temsil eden Japonya'nın NHK ve Çin'in CCTV ce CGTN uluslararası ölçekte yayın yapan kanalları da örnekler içinde yer almaktadır.

\section{Yeni Medya Haber Gündeminin Olușumunda Etkin Olan Araç ve Aktörler}

Günümüzde de, dördüncü kuvvet olma özelliğini koruyan medya, gelişen teknolojinin imkânlarından da faydalanmaktadır. Bir taraftan uydu yayıncılığını ve diğer taraftan internet gücü ile etkinlik alanını genişletmektedir. Şüphesiz interneti bir güç olarak tanımlarken bu uluslararası ağın (internetin) uyduların, uydu baz istasyonlarının, uydu hizmetlerine bağlı sabit kablo ağlarına ve dijital hizmet veren $3 \mathrm{G}, 4 \mathrm{G}, 5 \mathrm{G}$ ve gelecekte $5 \mathrm{G}+$ ile iletişim hatlarına ve uydu hizmetlerine bağlı olduğunu unutmamak gerekmektedir. Uydu ve internet yayıncılığı ile akış hızı yüksek bilgi ve enformasyon trafiği yaşanmaktadır.

2018 y1lı verilerine göre, Dünya'nın uzay boşluğunda 1957 aktif uydu aracı bulunmaktadır. [47] Bu uydulardan 849'u ABD'ye, 152'si Rusya'ya, 284'ü Çin'e ve 672'si de diğer ülkelere ait bulunmaktadır. ABD'nin 24'ü sivil, 488'i ticari, 170'i kamu kurumlarının ve 167'si ise askeri amaçlı uydu bulunmaktadır.[48] Bu toplam 1957 uydunun 1232'si LEO (alçak dünya yörüngeli), 126'sı MEO (orta dünya yörüngeli), 41'i Eliptik ve 551'i de GEO (jeostatik) [49] yörüngeli uydulardır.

Bu teknolojik imkânlarının yanı sıra bir de internet üzerinden bilgisayar, tablet ve akıllı mobil telefonlar ile kolaylıkla kullanılan ve eş zamanlı iletişim ve bilgi akışı sağlayan sosyal medya araçları ile internete yeni bir güç olma özelliği atfedilmektedir. Bu güç atfından kaynaklı olarak interneti tek başına bir “ Beşinci kuvvet" olarak tanımlamanın yerine yeni medyaya paralel olarak kişi ve grup bazlı mülkiyet sahipliğindeki sosyal medya kendi başına ve ayrıca belli zaman dilimleri içinde ön plana çıkan sosyal medya araçlarının da her biri göreceli ayrı bir güç olarak tanımlanabilir. Bu çıkarsamadan hareket ile de sosyal medyada zaman zaman popüler olan veya o popülerliklerini modaya göre yitiren sosyal medya uygulamalarının uygulama ve hesap sahibi kullanıcılarına da bir popülerlik kattığı görülmektedir.

$\mathrm{Bu}$ anlamda, yeni medya kitle iletişim araçları içinde olan sosyal medya uygulamalarının çağımızda, kendi uygulamalarını kullanan bireysel kullanıcılarına onların toplum içindeki statülerine göre bir imtiyaz sağladığı görülmektedir. Bir bakıma, özellikle Twitter gibi sosyal medya araçlarının kullanıcıları eğer elit (siyasi, zengin işadamı, yazar, bilim adamı, eleştirmen, sinema yıldızı veya ünlü bir şarkıcı) ise kendi bireysel hesapları ile PR alanlarını ve mesajlarını okutma ve videolarını izletme sayılarını yüksek ve geniş tutabilmektedirler.

Sosyal medya vasıtasıyla hâsıl olan bu durumu, klasik ve yeni medya kitle iletişim araçları arasında yer alan ve halen de gündem oluşturmada etkisini sürdüren, gazete, dergi, radyo ve televizyonunun yukarıdan aşağıya medya mülkiyet sahipleri, eşik bekçileri ve elit medya çalışanları üzerinden aşağıya doğru toplum veya toplumdaki hedef kitlelere (okuyucu, dinleyici ve izleyici) (Şekil 5) bilgiyi ulaştırma sürecinden farklı olarak, sosyal medya kullanıcısı elitin tek başına mülkiyet sahibi olmadığı[50] bir sosyal medya uygulaması üzerinden kişisel kullanıcı sıfatıyla topluma veya hedef kitlelerine ulaşması sürecine geçilmiş olması şeklinde tanımlanabilir. (Şekil 6) 


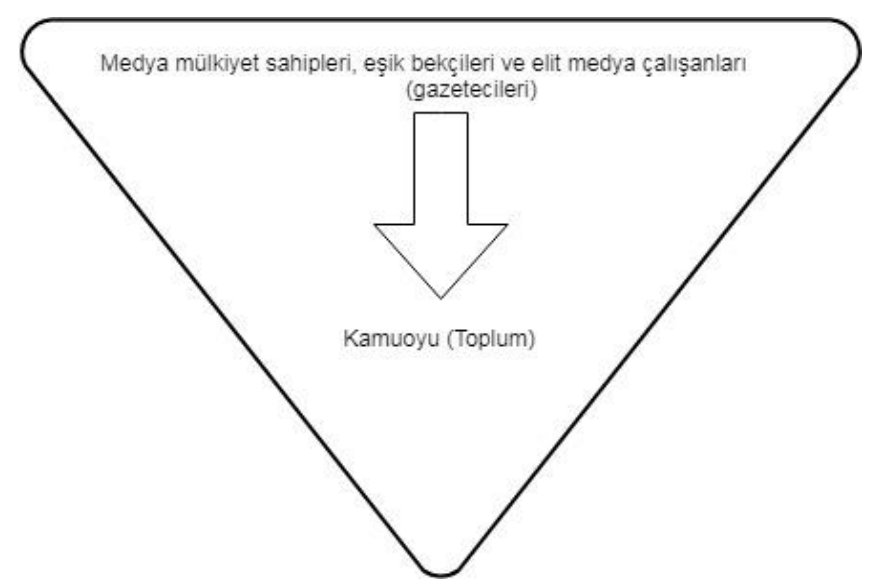

Şekil 5. Yukarıdan Aşağıya Kamuoyunun Etkilenmesi[51]

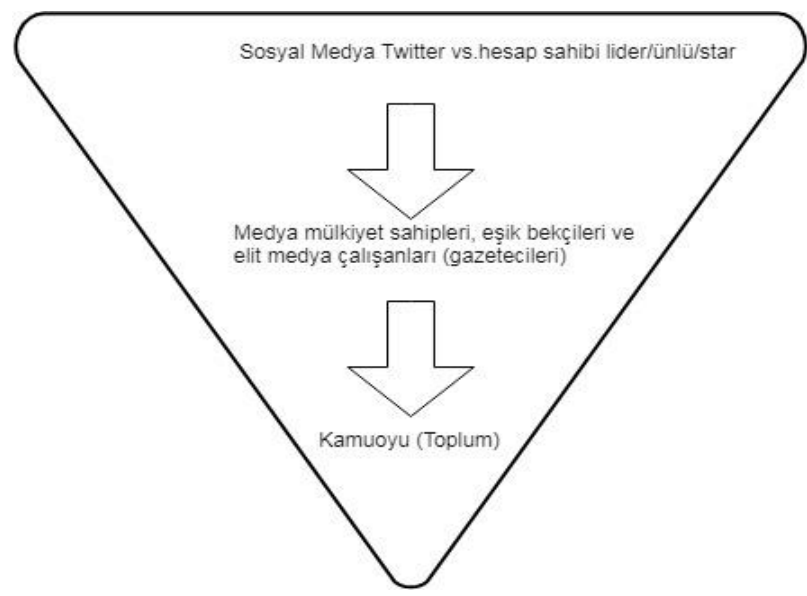

Şekil 6. Sosyal Medya Hesap Sahibi Liderlerin (veya Ünlü ve Starların) Haber Gündemini Yukarıdan Aşağıya Dikey Tek Taraflı Etkilemesi[52]

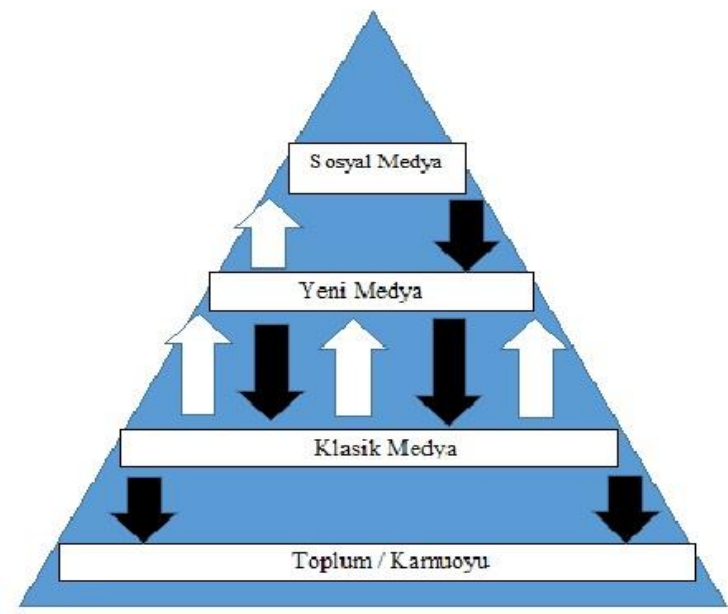

Şekil 7. 4.Kuvvet Medya Üçgeni[53]

Ancak bu yeni sürecin etkinliğinin yeni medya konseptinden ayırarak sosyal medyayı bir beşinci kuvvet yapması imkânsızdır. Sosyal medya yeni medya konseptine sadece yenilik getirmekte ve ayrı bir güç 
katmaktadır. Sosyal medya zaten dördüncü kuvvet olma özelliğini "de jure” olmasa da "de facto" olarak yeni medya çatısı altında sürdürmektedir. Bu yapıyı aynı üçgenin kademelerinden biri olarak tanımlanabilir. Her geçen gün, farklı yenilikler ile sosyal medya araçlarının ve uygulamalarının siyasal iletişimde yerini alması yeni medyaya maddi zenginlik kazandırdığı gibi, siyasal iletişimi kullanan aktörlere de geniş kitlelere hızlı ve kolayca erişim imkânı sağlamaktadır.

İnternetin sağladığ hızlı, çabuk bilgi akışı ve erişim rahatlığı, medya, kamu ve siyasi gündemlerin oluşmasında medya aracılığıyla kitlelere dolayısıyla kamuoyuna ulaşan aktif bireylere (ki bunlar tek başlarına siyasi şahsiyetler olabileceği gibi, lobi veya siyasal iletişim faaliyetlerini yürüten kişi ve gruplar veya ikili ilişki içinde tanımlanan kaynak kişiler olabilir) güç kazandırmaktadır.

\section{Beşinci Güç Kavramı Üzerinde Felsefi Değerlendirme}

İnternetin tek başına bir V. Kuvvet olmasından öte internet üzerinden güç olan bir medya yapılanması ile karşı karşıya bulunulmaktadır. Basım, basın ve medya sektörleri her zaman tarihsel süreçte teknolojik gelişmelerden faydalanarak, sektörel kârlarını maksimize etmek ve çok kişiye ulaşmayı hedeflemişlerdir. Batı'da özellikle ayakta kalanlar medya şirketleri de zaten, kısa vadeli ve belli bir süre içinde para kazanmayı, sınırlı siyasi baskı oluşturmayı veya başka sektörlerdeki gayri meşru kazançlarını aklama düşüncelerinden muaf olanlardır. Telgraf ajanslığından internet ajanslığına varılan teknolojik süreç içinde, internetin gücü medyaya güç katmıştır. Esasında, internet yatırımlarının gelişmesi onun ilintili olduğu ticari sektörlerin talebine de bağlıdır. Internet tek başına bir güç değildir. İnternet ona bir uygulama, bir ara yüz veya bir navigasyon uygulaması ile bağlı olunduğu (veya bağlantı sağlandığı) zaman anlam kazanan bir güç haline dönüşmektedir. Doğal olarak, burada internetin alt yapısı, hızına ilişkin teknolojik yatırımlarda önem taşımaktadır. Bu durum bir bakıma, sahip olunan mükemmel seyahat aracının işlevselliğinin sadece mekanik donanımı ve konfor imkânlarına değil aynı zamanda onun yakıt ihtiyacının karşılanmış olmasına, yol durumuna ve ehil olan sürücüsüne bağlıdır. [54]

Bir bakıma, internet ve medya birbirine çok yönlü ve çok taraflı bağlılığı ifade etmektedir. Aksi takdirde, dijital bir iletişim olan internetin çok fazla faktör ve aktöre ihtiyacı vardır. Diğer bir ifade ile havayı dolduran radyo ve televizyon yayın frekanslarının, radyo ve televizyon cihazları olmadan hiçbir şey ifade etmeyeceği ve özellikle de dinleyicisi ve izleyicisi olmayan yayınların ise maddi boyuttaki varlıklarının, soyut boyutta yokluğu ve etkisizliği ifade etmesi gibi bir durum söz konusu olabilmektedir. Bu güç gibi görünen nesnenin esasında etki gücünün ve ağırlığının olmaması anlamına gelmektedir. Bu karşılaştırma basılı yayınlar için baskı sayısı, radyo ve televizyon kanalları için aktif ve sürekli dinleyici ve izleyici sayıları, yayın platformları için abone sayısı, internet uygulamalarının kullanımında kullanıcı sayısı ve sosyal medya uygulamalarının kullanımında kullanıcı sayısı ve ayrıca aktif hesap kullanıcı sayısı ile ölçülmektedir. Bununla beraber, metaforik karşılaştırma ile fiziki ağırlığı olmayan kütlelerin sanki bir yağmur bulutu gibi güneşi örtmesi, ışığı kesmesi gibi zaman zaman sağlıklı bilgi trafiğinin de kesilme riski bulunmaktadır. Bu bağlamda ortaya atılan V. Kuvvet kavramı esasında, Frankurt Okulu'nun haklı ve kökten eleştirilerine rağmen IV. Kuvvet[55] olarak tasvir edilen ve bu özelliğini korumaya çalışan klasik medya araçlarının yanı sıra, 2003 yılında yazdığı eleştirel yazı ile liberal küreselleşme ile medyanın anlamını yitirdiğini söyleyen Ignacio Ramonet' in ele aldığı "Beşinci Kuvvet” kavramında atıf yapılan kavram “yurttaş kuvveti” dir[56]. Ramonet, beşinci kuvvet olarak yasama, yürütme, yargı ve medyaya ek olarak ihtiyaç olan sivil inisiyatif ve sivil katılım üzerinde durmaktadır. 2003 yılında literatüre giren beşinci kuvvet kavramına ilaveten diğer taraftan literatüre 2013 yılında gösterime giren "Wikileaks: Beşinci Kuvvet”[57] filmi ile sonrasında internet ve medya araştırmalarında V. Kuvvet kavramı kavramsallaşmaya başlamıştır. Gerçekte uluslararası bir ağ olmanın ötesinde internet, ayrıca yasama, yürütme, yargı ve medya gibi bir güç olma veya bir gücün yerine ikame edilecek bir reel güç değil sadece sanal bir alan veya evrendir. [58]

Ancak, bu evren içinde bir güçten bahsedilecek ise, bunun iletişim araçları vasıtasıyla sağlanan bir hâkimiyet ve kontrol gücü olduğu ifade edilebilir. Ayrıca, bu gücün oluşmasına katkı sağlayan iletişim araçlarının ve uygulamalarının her birinin nitelik ve nicelikleri de bu sanal evrendeki etkileme, kullanım ve talep potansiyellerine göre sahip oldukları değerleri ve popülerlikleri ile oluşturulan sıralama çerçevesinde sinıflandırılmaktadır.

$\mathrm{Bu}$ süreç sonrasında ise internet evrenindeki bu iletişim araçlarının ve uygulamalarının, hangisinin daha çok etkin olduğu ayrıştırılmasından çok hangisinin daha fazla bir siyasal iletişim aracı olarak siyasiler ve liderler tarafından diğerlerinin yanında tercih edildiğinin üzerinde durulması gerekmektedir. Doğal olarak, bu uygulamaların içinde, diğer sosyal medya araçlarına nazaran Twitter' in dünya liderleri tarafindan sıcça kullanılması ve bu sosyal medya iletişim aracı vasıtasıyla yayınladıkları tweetlerin yarattığı domino etkisiyle haber gündemi oluşturması ayrıca literatüre diplomasi, kamu diplomasi ve kültür diplomasi 
terimlerinden sonra Twitter diplomasisi şeklinde geçen “Twitdiplomacy” kavramı Twitter’1 diğer sosyal medya ve iletişim araçları arasında şimdilik popüler olmasını sağlamıştır.

\section{Dördüncü Kuvvet Yeni Medyanın Sosyal Medya Araçları: Twitter}

Kurulduğu 2006 yılından beri popülerliğini artarak yaygınlaştıran, dünya borsalarında TWTR kodu ile işlem gören Twitter şirketinin[59] piyasa değeri 24.7 milyar Amerikan doları civarında olup, dünyada dijital şirket siralamasında 100 şirket arasında 21.sırada sıralanmaktadır. [60]

Twitter'ın 2018 yılında yayınlanan istatistiki verilerine göre[61];

“...aylık aktif Twitter kullanıcı sayısı 326 milyon civarındadır. Dünyada günlük atılan "tweet” sayısı 500 milyondur. Twitter kullanıcılarının \%80'i mobil kullanicılardır. Aktif kullanıcı sayısı 100 milyondur.

\section{Twitter'ın demografik verileri;}

- Tüm internet erkek kullanıcılarının \%24'ü, kadın kullanıcıların ise \%21'i Twitter kullanmaktadır.

- Amerika Birleşik Devletleri'nin dışında hesabı olan toplam 261 milyon uluslararası Twitter kullanıcısının oranı \%79'a ulaşmaktadır.

- Amerika Birleşik Devletleri'nde 69 milyonun üzerinde Twitter kullanıcısı mevcuttur.

- Kabaca, Twitter kullanicılarının \%46'sı Twitter'ı her gün kullanmaktadırlar.

- Birleşik Krallık'ta Twitter kullanicılarınin sayısı 13 milyon civarındadır.

- Twitter kullanıcılarının \% 37'si 18-29, \%25 oranındaki kullanıcı ise 30-49 yaşları arasında bulunmaktadir.

- 18-29 yaş arasindaki Amerikalıların \%36'sı Twitter'ı kullanmaktadır.

- Twitter kullanıcılarınin \% 56'sl yllda 50.000 Amerikan dolarl veya üzerinde bir gelire sahiptir.

- Amerika Birleşik Devletleri'nin dişında Twitter kullanıcı sayısı en fazla olan ü̧̈ ülke Brezilya (27.7 milyon kullanicl), Japonya (25.9 milyon kullanıcı) ve Meksika ( 23.5 milyon kullanıcı) siralanmaktadir.

- Twitter kullanicılarının \%80'i Twitter platformunu mobil cihazlar aract ile kullanmaktadir. Video izlemelerinin \%93'ü de mobil cihazlardan yapılmaktadır.

Twitter'm finans verileri;

- $\quad$ Twitter'in geliri: 711 milyon Amerikan dolarıdır.

- $\quad$ Toplam reklam geliri: 545 milyon Amerikan dolarl (Bu gelirin 374 milyon Amerikan dolarl Amerika Birleșik Devletleri, 242 milyon Amerikan doları ise uluslararası elde edilen reklam geliridir), yıllık\% 6 oraninda reklam gelirinde artıs gözlenmektedir.

- $\quad$ Mobil reklam geliri toplam reklam gelirinin \%88'ini teskil etmektedir.

\section{Twitter hakkinda genel bilgiler:}

- $\quad$ Twitter 18 kentilyonluk bir hesap alanina sahiptir.

- $\quad$ Twitter kullanıclarının \%74'ü Twitter'i kendi haklarındaki haberleri takip etmek için kullandıklarını söylemektedirler.

- $\quad$ Küçük ve orta sinıf işletme sahiplerinin \%85'i Twitter'ı kendilerine müssteri çekmek için kullandıklarını söylemektedirler.

- 2015 yllinda 100 milyondan fazla tweet GIF içerikli tweet olduğu tespit edilmişstir.

- $\quad$ Suudi Arabistan'da internet kullanıcılarının yüksek oranı aktif Twitter kullanıcısıdır.

- 2017 yllının üçüncü çeyreğinde, Twitter 830'dan fazla etkinliği canlı yayınlamıștır.

- $\quad$ Twitter aynı zamanda Periscope aracıllğ̆ ile yılın üçüncü çeyreğinde 96 milyon saat canlı yayın akıșı yapmiștır.

- 2014 yllinda 200 milyar defa Twitter zaman cizelgesine bakalmısttr.

- Birleşmis Milletler Örgütüne üye 193 üye ülkenin \%83'ünün Twitter hesabı vardır.

- Twitter çalıșanı kiși bașına geliri ortalama 488,913 Amerikan dolarıdır.” [62]

Yukarıda yer alan Twitter'a ait verilerde görüldüğü gibi, Twitter bir anlamda dünyanın her yayına yayılması, birçok ülkede yapılanmasının olması ve uluslararası niteliğinden dolayı "Dijital Çokuluslu Şirket”(DÇUŞ) veya "Elektronik Çokuluslu Şirket” (EÇUŞ) olarak tanımlanabilir. Diğer taraftan, Twitter'ın yeni medyanın bir aracı şeklinde kullanılması, gazete, televizyon, radyo şirketlerinden haber ajanslarına kadar yerel, ulusal ve uluslararası boyutta faaliyet gösteren tüm medya iletişim şirketlerinin birer Twitter hesabına sahip olmasından ve bu aktörlerin internet haberciliğinde ayrıca Twitter kullanmalarından kaynaklandığ gözlenmektedir. Dolayısıyla, haber ve habere bağlı gündem akışı Twitter üzerinden de gerçekleşmektedir. Twitter'ın bu popülerliğinin ne kadar süreceği bir soru işareti ise de günümüzde Twitter'n yerine 
kullanılacak bir sosyal medya uygulamasının popüler olmasına kadar, özellikle siyasette ve sanat dünyasında popüler olanlar için bir dijital platform olacağı açıktır. Medya dünyasının geleceğinde ise tamamen farklı bir uygulamanın ikame edilmesi her zaman mümkün gözükmektedir.

Verill' in tahminlerine göre de "Geleceğin en büyük icatlarının ve iyileştirme çalışmalarının çoğunun, hayal bile edilmemiş olan şeyleri, deneyler yaparak gerçekleştirme şansının amatörlerden gelmesi büyük olasılıkla muhtemeldir." [63] Gerçekte de bu öngörü ışığında Twitter Verill'in bu öngörüsünden sonra sosyal medya dünyasında popüler olmaya başlamıştır. Bu kapsamda, Twitter ve diğer sosyal medya platformlarının bilgileri ile karşılaştırıldığında, Twitter'ın önemli bir sosyal medya platformu olduğunu ancak kullanıcı sayısı bakımından karşılaştırıldığında, Twitter kullanıcı sayısının Facebook, Instagram, Youtube ve Linkedin kullanıcı sayılarından düşük olduğu görülmektedir. Bununla beraber, Twitter'ın 2018 yılı verilerine göre aylık aktif 326 milyon kullanıcısının olması ve Twitter'da yayınlanan tweetlerin daha çok siyasi görüş, yorum ve beyanlar olması ve de özellikle bu siyaset ve sanat alanında en üst düzeyde olan kullanıcıların tweetlerinin haber gündeminde önemsenmesi Twitter'1 diğer sosyal medya platformlarından farklı kılmaktadır. Ayrıca Twitter kullanıcılarının takip edecekleri hesaba ilişkin bir takipçi sınırlaması olmaması ve Twitter hesabı üzerinden paylaşılan tweetlerin bir anda milyonlar ile ifade edilen takipçilerin her birine ve hedef kitlelere anında ulaşması bir tweet tsunamisi etkisi yapmaktadır. Forbes'in en iyi 100 dijital şirket sıralamasında piyasa değeri açısında karşılaştırıldığında kullanıcı sayısı bakımından Facebook'un çok gerisinde bulunan Twitter 21. sirada bulunurken, Facebook ise 26. sirada bulunmaktadir.[64]

\section{Twitter ve Diğer Sosyal Medya Platformlarının Makro Verileri}

$\mathrm{Bu}$ kısımdaki tablolarda, Twitter ve Instagram, Snapchat, Facebook, Youtube, Linkedin, Pinterest ve Persicope gibi diğer sosyal medya platformlarının makro verileri yer almaktadır. Makro düzeydeki bu veriler platformlar arasında karşılaştırma yapmaya imkân vermektedir.

Tablo 1. Facebook Kullanım Verileri (Kişi Başına), Eylül 2018

\begin{tabular}{|c|c|c|c|c|}
\hline $\begin{array}{c}\text { Aylık Aktif } \\
\text { Kullanıcıların } \\
\text { Toplam Sayısı }\end{array}$ & $\begin{array}{c}\text { Aylık Aktif } \\
\text { Mobil } \\
\text { Kullanıcıların } \\
\text { Toplam Sayısı }\end{array}$ & $\begin{array}{c}\text { Aktif Günlük } \\
\text { Masaüstü } \\
\text { Bilgisayar } \\
\text { Kullanıcıların } \\
\text { Toplam Sayısi }\end{array}$ & $\begin{array}{c}\text { Günlük Aktif } \\
\text { Mobil } \\
\text { Kullanıcıların } \\
\text { Toplam Sayısı }\end{array}$ & $\begin{array}{c}\text { Günlük Hikâye } \\
\text { Akışının } \\
\text { İzlenilme Sayısı }\end{array}$ \\
\hline 2.23 milyar & 1.74 milyar & 1.47 milyar & 1.57 milyar & 150 milyon \\
\hline
\end{tabular}

Kaynak: Omnicore, "Internet Statistics", https:/www.omnicoreagency.com/category/internet-stats/, erişim tarihi: 26 Şubat 2019

Tablo 2. Instagram, 2018

\begin{tabular}{|c|c|c|c|c|c|c|}
\hline $\begin{array}{l}\text { Aylık Aktif } \\
\text { Kullanıcıların } \\
\text { Toplam } \\
\text { Sayısı }\end{array}$ & $\begin{array}{l}\text { Günlük Aktif } \\
\text { Kullanıcıların } \\
\text { Toplam } \\
\text { Sayısı }\end{array}$ & $\begin{array}{c}\text { Günlük } \\
\text { Hikâye } \\
\text { Akışı } \\
\text { Aktif } \\
\text { Kullanıcı } \\
\text { Toplam } \\
\text { Sayısı }\end{array}$ & $\begin{array}{c}\text { Paylaşılan } \\
\text { Fotoğraf } \\
\text { Sayısı } \\
\text { Toplamı }\end{array}$ & $\begin{array}{l}\text { Instagram'daki } \\
\text { İşletme Sayısı }\end{array}$ & $\begin{array}{l}\text { Günlük } \\
\text { “Beğeni” } \\
\text { Sayıs1 }\end{array}$ & $\begin{array}{c}\text { Günlük } \\
\text { Paylaşılan } \\
\text { Fotoğraf } \\
\text { ve Video } \\
\text { Sayıs1 }\end{array}$ \\
\hline 1 milyar & 500 milyon & $\begin{array}{c}400 \\
\text { milyon }\end{array}$ & 50 milyar & 25 milyon & 4.2. milyar & $\begin{array}{l}100 \text { milyon } \\
\text { ve üzeri }\end{array}$ \\
\hline
\end{tabular}

Kaynak: Omnicore, "Internet Statistics", https://www.omnicoreagency.com/category/internet-stats/, erişim tarihi: 26 Şubat 2019 
International Journal of Scientific and Technological Research

ISSN 2422-8702 (Online), DOI: 10.7176/JSTR/5-8-12

Vol.5, No.8, 2019

Tablo 3. Snapchat, 2018

\begin{tabular}{|c|c|c|c|c|c|c|c|}
\hline \begin{tabular}{|c|} 
Aylık Aktif \\
Kullanıcıların \\
Toplam \\
Sayısı
\end{tabular} & $\begin{array}{l}\text { Günlük Aktif } \\
\text { Kullanıcıların } \\
\text { Toplam Sayısı }\end{array}$ & $\begin{array}{c}\text { Snapchat'1 } \\
\text { Kullanan ABD } \\
\text { Sosyal Medya } \\
\text { Kullanıcilarının } \\
\text { Oranı }\end{array}$ & \begin{tabular}{|c|} 
Hergün \\
Yaratılan \\
Fotoğraf ve \\
Video \\
Sayısı
\end{tabular} & $\begin{array}{l}\text { Kullanıcıların } \\
\text { Snapchat } \\
\text { Kullanırken } \\
\text { Günlük } \\
\text { Geçirdikleri } \\
\text { Zaman Süresi }\end{array}$ & \begin{tabular}{|c|} 
ABD'de 18- \\
24 Yaş \\
Grubu \\
Arasındaki \\
Kullanıcıların \\
Oranı
\end{tabular} & $\begin{array}{l}\text { ABD ve } \\
\text { Kanada'da } \\
\text { Aylik } \\
\text { Kullanıcı } \\
\text { Sayısı }\end{array}$ & \begin{tabular}{|c|} 
Günlük \\
Olarak \\
Videoları \\
Seyretme \\
Sayıs1
\end{tabular} \\
\hline $\begin{array}{c}300 \text { milyon } \\
\text { ve üzeri }\end{array}$ & 188 milyon & $\% 18$ & 3 milyar & $30 \mathrm{dk}$ ve üzeri & $\% 78$ & $\begin{array}{c}100 \text { milyon } \\
\text { ve üzeri }\end{array}$ & \begin{tabular}{|c|}
10 \\
milyardan \\
fazla
\end{tabular} \\
\hline
\end{tabular}

Kaynak: Omnicore, "Internet Statistics", https://www.omnicoreagency.com/category/internet-stats/, erişim tarihi: 26 Şubat 2019

Tablo 4. Twitter, 2018

\begin{tabular}{|c|c|c|c|}
\hline $\begin{array}{c}\text { Aylık Aktif } \\
\text { Kullanıcıların Toplam } \\
\text { Sayısı }\end{array}$ & $\begin{array}{c}\text { Günlük Paylaşılan } \\
\text { Toplam Tweet Sayısı }\end{array}$ & $\begin{array}{c}\text { Mobil Üzerinden } \\
\text { Kullanım Oranı }\end{array}$ & $\begin{array}{c}\text { Günlük Aktif Kullanıc1 } \\
\text { Sayısı }\end{array}$ \\
\hline 326 milyon & 500 milyon & $\% 80$ & 100 milyon \\
\hline
\end{tabular}

Kaynak: Omnicore, "Internet Statistics", https://www.omnicoreagency.com/category/internet-stats/, erişim tarihi: 26 Şubat 2019

Tablo 5. Youtube, 2018

\begin{tabular}{|c|c|c|c|c|c|c|c|c|}
\hline $\begin{array}{c}\text { Aylık Aktif } \\
\text { Kullanıcıların } \\
\text { Toplam } \\
\text { Sayıs1 }\end{array}$ & $\begin{array}{c}\text { Günlük Aktif } \\
\text { Kullanıcıların } \\
\text { Toplam } \\
\text { Sayıs }\end{array}$ & $\begin{array}{c}\text { Youtube } \\
\text { Paralı TV } \\
\text { Aboneliği } \\
\text { Olanlar }\end{array}$ & $\begin{array}{c}\text { Toplamda } \\
\text { Paylaş1lmış } \\
\text { Video } \\
\text { Sayıs1 }\end{array}$ & $\begin{array}{c}\text { İçerik } \\
\text { Ureterek } \\
\text { Paylaşan } \\
\text { Kullanıc1 } \\
\text { Sayı1 }\end{array}$ & $\begin{array}{c}\text { Yıllık } \\
\text { Ortalama } \\
\text { Seyretme } \\
\text { Süresi }\end{array}$ & $\begin{array}{c}\text { Seyredilen } \\
\text { Videoların } \\
\text { Günlük } \\
\text { Sayı1 }\end{array}$ & $\begin{array}{c}\text { Günlük } \\
\text { Mobil } \\
\text { İzlenim } \\
\text { Sayıs1 }\end{array}$ & $\begin{array}{c}\text { Dakikada } \\
\text { Yüklenen } \\
\text { Video } \\
\text { Sayıs1 }\end{array}$ \\
\hline 1.9 milyar & $\begin{array}{c}30 \text { milyon ve } \\
\text { üzeri }\end{array}$ & 300.000 & $\begin{array}{c}5 \text { milyar ve } \\
\text { üzeri }\end{array}$ & $\begin{array}{c}50 \\
\text { milyon }\end{array}$ & $40 \mathrm{dk}$ & 5 milyar & $\begin{array}{c}500 \\
\text { milyon }\end{array}$ & 300 saat \\
\hline
\end{tabular}

Kaynak: Omnicore, "Internet Statistics", https://www.omnicoreagency.com/category/internet-stats/, erişim tarihi: 26 Şubat 2019

Tablo 6. Linkedin, 2018

\begin{tabular}{|l|l|l|l|l|}
\hline $\begin{array}{l}\text { Toplam Kullanıc1 } \\
\text { Sayısı }\end{array}$ & $\begin{array}{l}\text { Aylı Toplam } \\
\text { Kullanıcı Sayıs1 }\end{array}$ & $\begin{array}{l}\text { ABD’deki } \\
\text { Kullanıcı Sayısı }\end{array}$ & $\begin{array}{l}\text { Linkedin Aylık } \\
\text { Kullanıc } \\
\text { Sayılarının Oranı }\end{array}$ & $\begin{array}{l}\text { Saniyede Eklenen } \\
\text { Yeni Üye Sayıs }\end{array}$ \\
\hline 590 milyon & 260 milyon & 154 milyon & $\% 44$ & 2 \\
\hline
\end{tabular}

Kaynak: Omnicore, "Internet Statistics", https:/www.omnicoreagency.com/category/internet-stats/, erişim tarihi: 26 Şubat 2019 
Tablo 7. Pinterest, 2018

\begin{tabular}{|l|l|l|l|l|l|}
\hline $\begin{array}{l}\text { Aylık Aktif } \\
\text { Kullanıcıların } \\
\text { Toplam } \\
\text { Sayısı }\end{array}$ & $\begin{array}{l}\text { ABD'deki } \\
\text { Kullanıcı } \\
\text { Sayısı }\end{array}$ & $\begin{array}{l}\text { Dünya } \\
\text { Toplam } \\
\text { Kullanıcı } \\
\text { Sayısı }\end{array}$ & $\begin{array}{l}\text { Toplam } \\
\text { Pinterest Pin } \\
\text { Sayısı }\end{array}$ & $\begin{array}{l}\text { Toplam } \\
\text { Pinterest } \\
\text { Pano Sayısı }\end{array}$ & $\begin{array}{l}\text { Günlük } \\
\text { Panolarda } \\
\text { Alışveriş } \\
\text { Amaçlı } \\
\text { Eklenen Pin } \\
\text { Sayısı }\end{array}$ \\
\hline 250 milyon & 125 milyon & $\% 50$ & 175 milyar & $\begin{array}{l}3 \text { milyar ve } \\
\text { üzeri }\end{array}$ & 2 milyon \\
\hline
\end{tabular}

Kaynak: Omnicore, "Internet Statistics", https://www.omnicoreagency.com/category/internet-stats/, erişim tarihi: 26 Şubat 2019

Tablo 8. Periscope, 2018

\begin{tabular}{|l|l|l|}
\hline Toplam Kullanıcı Sayısı & Günlük Aktif Kullanıcı Sayısı & $\begin{array}{l}\text { Toplamda Yapılmış Olan Yayın } \\
\text { Sayısı }\end{array}$ \\
\hline 10 milyon & 1.9 milyon & 200 milyon \\
\hline
\end{tabular}

Kaynak: Omnicore, "Internet Statistics", https://www.omnicoreagency.com/category/internet-stats/, erişim tarihi: 26 Şubat 2019

Tablo 9. Sosyal Medya Platformlarının Piyasa Değeri ( ABD doları)

\begin{tabular}{|l|l|l|l|l|l|l|l|}
\hline Facebook & Instagram & Snapchat & Twitter & Youtube & Linkedin & Pinterest & Periscope \\
\hline $\begin{array}{l}541.5 \\
\text { milyar }\end{array}$ & $\begin{array}{l}100 \text { milyar } \\
\text { ve } \\
\text { üzeri[65] }\end{array}$ & $\begin{array}{l}24.4 \\
\text { milyar }\end{array}$ & $\begin{array}{l}24.7 \\
\text { milyar }\end{array}$ & $\begin{array}{l}160 \\
\text { milyar }\end{array}$ & $\begin{array}{l}15.8 \\
\text { milyar }\end{array}$ & 30 milyar & $\begin{array}{l}86 \text { milyar } \\
\text { ve üzeri }\end{array}$ \\
\hline
\end{tabular}
https://www.forbes.com/companies/facebook/\#b9658b04193e, erişim tarihi:26 Şubat 2019 ; Instagram bkz. Emily McCormick, "Instagram Is Estimated to Be Worth More than \$100 Billion", Bloomberg, 25 Juin 2018, https://www.bloomberg.com/news/articles/2018-06-25/value-of-facebook-s-instagram-estimated-to-

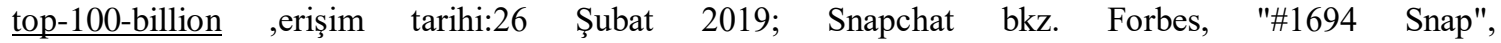
https://www.forbes.com/companies/snap/\#6f437923704d , erişim tarihi:26 Şubat 2019; Twitter bkz. Forbes, "\#21 Twitter", https://www.forbes.com/companies/twitter/\#52747e7022a3 , erişim tarihi:26 Şubat 2019; Youtube bkz. Greg Sandoval, Business Insider, "Morgan Stanley figured out how much YouTube would be worth if it were a separate company, and it's more valuable than Disney", 18 May 2018, https://www.businessinsider.com/morgan-stanley-values-youtube-160-billion-dollars-2018-5 , erişim tarihi:26 Şubat 2019; Linkedin bkz. Forbes, "\#294 LinkedIn", https://www.forbes.com/companies/linkedin/\#6b9ae5443a5e , erişim tarihi:26 Şubat 2019; Pinterest bkz. Forbes, "Can $\quad$ Pinterest $\quad$ Be $\quad$ A $\quad \$ 30 \quad$ Billion Company?", https://www.forbes.com/sites/greatspeculations/2018/06/15/can-pinterest-be-a-30-billioncompany/\#84edf816c3fb , erişim tarihi:26 Şubat 2019

\section{Twitter Kullanıcısı Dünya Liderleri ve Siyasi Kurumlar}

Twitter popülerliğini sürdürdüğünden beri, dünyada hemen hemen her ülke siyasileri ve liderleri Twitter'1 bir siyasal iletişim stratejileri içinde bir siyasal iletişim aracı olarak kullanmaktadırlar. Doğal olarak Twitter'ın diğer sosyal medya araçları arasındaki diğer uygulamalardan farklı olarak kullanıcıya sınırsız sayıda takipçi imkânı vermesi, bu sayıların kullanıcı açısından kullanıcıya olan ilgi ve önemin değerlendirilmesi sınıflandırılmasında ölçü olmaktadır. Takipçilerin sayısı bir bakıma kullanıcıya olan ilgi ve önemin diğer kullanıcı, siyasiler ve liderler ile karşılaştırıldığında çok yüksek, yüksek, orta ve aşağ düzeylerde kategorileştirilmesini sağlamaktadır. 
Tablo 10. 7 Mart 2019 Tarihinde Twitter’ı Kullanan ve İlk 25 Siralaması İçinde Yer Alan Dünya Liderleri ve Kurumları

\begin{tabular}{|c|c|c|c|c|c|c|}
\hline Liderler / Kurumlar & $\begin{array}{c}\text { Tweet } \\
\text { Sayıs1(Bin) }\end{array}$ & $\begin{array}{l}\text { Takip } \\
\text { Edilen } \\
\text { (kişi) }\end{array}$ & $\begin{array}{l}\text { Takipçi } \\
\text { Sayis1 } \\
\text { (Milyon) }\end{array}$ & Beğeni & Anlar & Liste \\
\hline $\begin{array}{l}\text { Donald J.Trump } \\
\text { @ realDonaldTrump } \\
\text { ABD [66] }\end{array}$ & 40.769 & 45 & 58.9 & 9 & 6 & \\
\hline $\begin{array}{l}\text { Pope Francis } \\
\text { @Pontifex } \\
\text { Vatikan }\end{array}$ & 1.893 & 8 & 17.9 & & & \\
\hline $\begin{array}{l}\text { Narendra Modi } \\
\text { @ narendramodi } \\
\text { Hindistab }\end{array}$ & 22.532 & 2.123 & 46.2 & & & \\
\hline $\begin{array}{l}\text { PMO India } \\
\text { @PMOIndia } \\
\text { Hindistan }\end{array}$ & 23.036 & 451 & 28.4 & & & \\
\hline $\begin{array}{l}\text { President Trump } \\
\text { @POTUS } \\
\text { ABD }\end{array}$ & 5.304 & 39 & 25.4 & 104 & & \\
\hline $\begin{array}{l}\text { The White House } \\
@ \text { WhiteHouse } \\
\text { ABD }\end{array}$ & 7.136 & 13 & 18.1 & 9 & & 2 \\
\hline $\begin{array}{l}\text { Recep Tayyip } \\
\text { Erdoğan } \\
\text { @RT_Erdogan } \\
\text { Türkiye }\end{array}$ & 5.639 & 4 & 13.5 & 3 & & \\
\hline $\begin{array}{l}\text { Sushma Swaraj } \\
\text { @ SushmaSwaraj } \\
\text { Hindistan }\end{array}$ & 6.108 & & 12.3 & 9 & & \\
\hline $\begin{array}{l}\text { Joko Widodo } \\
\text { @ jokowi } \\
\text { Endonezya }\end{array}$ & 1.509 & 60 & 11 & 2 & & \\
\hline $\begin{array}{l}\text { Rania Al Abdullah } \\
\text { @QueenRania } \\
\text { Ürüdn }\end{array}$ & 2.096 & 46 & 10.4 & 2 & & 4 \\
\hline $\begin{array}{l}\text { HH Sheikh } \\
\text { Mohammed } \\
@ \text { HHShkMohd } \\
\text { Birleşik Arap } \\
\text { Emirlikleri }\end{array}$ & 5.533 & 62 & 9.52 & & & \\
\hline $\begin{array}{l}\text { Imran Khan } \\
\text { @ImranKhanPTI } \\
\text { Pakistan }\end{array}$ & 5.792 & 19 & 9.33 & & & \\
\hline 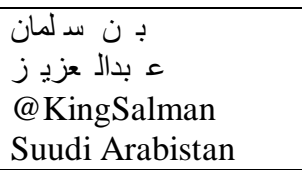 & 326 & & 7.31 & & & \\
\hline $\begin{array}{l}\text { T.C. } \\
\text { Cumhurbaşkanlığı } \\
\text { @tcbestepe } \\
\text { Türkiye }\end{array}$ & 9.578 & 8 & 6.47 & & & \\
\hline $\begin{array}{l}\text { UK Prime Minister } \\
\text { @ 10DowningStreet } \\
\text { İngiltere }\end{array}$ & 12.971 & 275 & 5,43 & 1.727 & 4 & \\
\hline
\end{tabular}




\begin{tabular}{|c|c|c|c|c|c|c|}
\hline $\begin{array}{l}\text { Department of State } \\
\text { @ StateDept } \\
\text { ABD }\end{array}$ & 58.869 & 455 & 5.23 & 25 & & 6 \\
\hline $\begin{array}{l}\text { Dmitry Medvedev } \\
\text { @MedvedevRussiaE } \\
\text { Rusya }\end{array}$ & 1.316 & 22 & 1.04 & & & \\
\hline $\begin{array}{l}\text { Andrés Manuel } \\
\text { @ lopezobrador_- } \\
\text { Meksika }\end{array}$ & 4.048 & 167 & 5.33 & 1 & & \\
\hline $\begin{array}{l}\text { Mauricio Macri } \\
\text { @ mauriciomacri } \\
\text { Arjantina }\end{array}$ & 9.275 & 643 & 4.78 & 103 & 1 & 5 \\
\hline $\begin{array}{l}\text { President of India } \\
\text { @ rashtrapatibhvn } \\
\text { Hindistan }\end{array}$ & 5.253 & 1 & 4.83 & 1 & & \\
\hline $\begin{array}{l}\text { Justin Trudeau } \\
\text { @ JustinTrudeau } \\
\text { Kanada }\end{array}$ & 21.912 & 957 & 4.46 & 70 & 16 & \\
\hline $\begin{array}{l}\text { Adullah Bin Zayed } \\
\text { @ ABZayed } \\
\text { Birleşik Arap } \\
\text { Emirlikleri }\end{array}$ & 9.374 & 627 & 4.43 & 642 & & \\
\hline $\begin{array}{l}\text { The Royal Family } \\
\text { @ RoyalFamily } \\
\text { İngiltere }\end{array}$ & 30.697 & 523 & 3.87 & 491 & 5 & 9 \\
\hline $\begin{array}{l}\text { Emmanuel Macron } \\
\text { @EmmanuelMacron } \\
\text { Fransa }\end{array}$ & 7.971 & 704 & 3.73 & 19 & & \\
\hline $\begin{array}{l}\text { Президент России } \\
\text { @ KremlinRussia } \\
\text { Rusya }\end{array}$ & 9.194 & 33 & 3.42 & & & \\
\hline
\end{tabular}

Kaynak: Twitter bilgileri 7 Mart 2019 tarihinde Twiplomacy.com, https://twiplomacy.com/ranking/the-50most-followed-world-leaders-in-2018/ internet sayfasındaki sıralama göz önünde tutularak bu makalenin yazarı tarafından ilgili hesaplar incelenerek güncellenmiştir. Ayrıca bkz. twiplomacy, https://twiplomacy.com/ranking/the-50-most-followed-world-leaders-in-2018/, erişim tarihi: 7 Mart 2109

Tablo 10'da görüldüğü gibi, Amerika Birleşik Devletleri başkanı Donald J. Trump en çok takipçisi olmasının yanı sıra 7 Mart 2019 tarihi itibariyle paylaştığ 40.769 tweet ile Twitter'ı en aktif kullanan dünya liderleri arasında birinci sırada bulunmaktadır. Bunun dışında, Birleşik Krallık Başbakanlık resmi Twitter hesabının 1.727 beğeni ile başka paylaşımları da takip ettiği görülmektedir. Tablo 10'da görülen diğer bir bilgi ise Twitter hesabına sahip olan dünya liderleri veya kurumların çok az sayıdaki kişiyi takip etmeleridir. Sosyal medya uygulamalarında, Facebook dışında, Twitter ve Instagram'da moda olan bu eğilime listede yer alan birçok lider uyarken, Kanada başbakanı Trudeau'nun takip ettiği 957 kişi ile "az kişiyi takip" modasının dışında hareket ettiği görülmektedir.

\section{Trump'ın Twitter Diplomasisi ve Twitter Aracılığı ile Uluslararası Piyasalara Verdiği Olumsuz Etkinin Değerlendirilmesi}

Yukarıda yer alan tüm bu genel açıklamalardan sonra, bu başlık altında Trump'ın Twitter'ı bir siyasal iletişim aracı olarak kullanması incelenmektedir.

ABD başkanı seçildiğinden beri Trump kendisi ile ilgili yoğun bir baskı altında kaldığını hissettiğinde veya Amerikan medya gündeminde Trump aleyhine ilişkin haberlerin sıklaştığı dönemlerde özellikle Twitter üzerinden farklı konularda tweetler yayınlayarak gündemi yayınladığı tweet içeriklerine göre şekillendirmeye çalıştığı görülmektedir. Bu konuda örneğin, Trump'ın başkan seçilmesinden 22 Mart 2019'da teslim edilen ve 24 Mart 2019 tarihinde açıklanan Rusya'nın Trump lehinde hile karıştırdığına dair bir delilin bulunmadığına ilişkin Mueller raporuna kadar geçen dönem içinde[67], doğrudan itham edildiği seçime hile karıştırdığına yönelik iddialar ve manipülasyon yaptığı suçlamalarının "yalancı medya" tarafından ileri sürüldüğünü devamlı söyleyerek, aniden dış politikada ya da iç politikada alacağı radikal 
kararlarını Twitter üzerinden açıklamıştır. Oysa medyanın gündeme taşıdığı Trump'a ilişkin haberler, sadece gazetelerin manşetlere taşıdığı bir olay değil aynı zamanda, konunun yargıya intikal etmesi neticesi Amerikan sisteminde hiç de alışık olunmayan bir durumu oluşturmuştur.

Trump ve ekibi hakkında özel yetkili danışman sıfatıyla Robert S. Mueller ve New York savcıları 17 Mayıs 2017 tarihinden itibaren soruşturma başlatmıştır.[68] Mueller soruşturması 22 Mart 2019'da tamamlanmış[69] ve soruşturma raporunda Trump'ı doğrudan hedef alan bir ifadeye yer verilmemiş ve bu durum Trump için siyasi bir zafer olarak tanımlanmıştır.[70] Bununla beraber, Mueller soruşturması kapsamında jüri tarafından suçlu bulunan Trump'ın danışmanı Roger Stone 25 Ocak 2019'da tutuklanmıştır.[71] Trump'ın diğer bir seçim danışmanı Paul Manafort'da hakkında 2017 yılında açılan davalardan suçlu bulunmuştur.[72] Trump hakkında yargıya taşınan diğer bir konu ise, Trump'ın 2016 başkanlık seçimleri sırasında aleyhinde özel ilişkilerini kamu ile paylaşmaması için susturmak amacıyla Stormy Daniels ve Karen McDougal'e para ödemesi vakasıdır. ABD siyaset ve hukuk sisteminde kişiye susturma amaçlı para ödenmesi kural dışı bir davranış olduğundan, Demokratlar Aralık 2018'de bu olayı Trump'ın başkanlık görevinden azledilebileceği şeklinde değerlendirmişlerdir.[73]

Ancak başkanlık görevine geldiğinden bu yana herkesten ve gündemden bağımsız hareket etmeyi seven Trump, üzerinde hissettiği siyasi ve yargı baskısına karşı Twitter üzerinden ülke politikasına ilişkin kendi gündemini medyanın cevabı ne şekilde olursa olsun oluşturmaktadır.[74] Eleştirel bir değerlendirme ile diplomasinin veya siyasetin uygulama alanı olarak Twitter üzerinden yapılmaması gerektiği sıkça vurgulansa da, başkanlık görevine geldiğinden beri Trump Twitter’’ bir diplomasi, siyasal iletişim ve siyasi manevra aracı olarak kullanmıştır ve halen de kullanmaya devam etmektedir. Yoğunlukla, ekonomi, ticaret ve finans odak haberleri ile tanınan Bloomberg'in, “Başkan Donald Trump, Twitter'ı Amerikan'ın ticaret ortaklarına, siyasi düşmanlarına ve medya şirketlerine saldırmak için kullanmaya büyük ehemmiyet veriyor. Ancak, dünyanın en büyük ekonomisinin ve halka açık ticaret şirketlerinin gücünü kutlamak için sık sık [medya önünde demeç vermektedir].. ’'[75] şeklindeki analizleri bir referans kaynağ olmaktadır.

Trump'ın Twitter' 1 bu şekilde bir siyasal iletişim aracı olarak aktif kullanmasının, Amerikalı sanatçılar tarafından bile "Trump için hiç bir şey kendi Twitter hesabından daha de ğerli değildir”'[76] biçiminde mizahi eleştirilere bile maruz kaldığı görülmektedir. Trump' ın aktif Twitter kullanıcılığına ilişkin eleştiriler ve bu konuya ilişkin hakkında gündem oluşmasında Amerikan ve uluslararası medyada yer alan haberlerin önemli bir rolü vardır. Örneğin, Fortune dergisinin Gallup anketine dayandırdığ 1 araştırmaya göre Amerikalıların dörtte üçünün bir vesile ile Trump' in tweetlerinden haberdar olduğu, \% 8'inin Trump'ı Twitter üzerinden takip ettikleri, \% 4'ünün ise bizzat takip listelerine ekledikleri ve \% 70'inin de Trump' in tweetlerini ikinci bir kaynaktan öğrendikleri şeklinde veriler ortaya konmaktadır. [77]

Trump'ın Twitter üzerinden gönderdiği tweetler sadece gündem oluşturmak ile kalmayıp, Trump tweetlerinin piyasaları nasıl etkilediğine ilişkin bir dizi medya haberlerinden[78] akademik makalelere, bildirilere ve ayrıca lisans düzeyinde sunulan posterlere de konu olmuştur. [79] Trump' ın yayınladığ 1 belli tweetleri ve o tweetlerin piyasalar üzerinde yaptığı etkiyi ekonometrik çalışmaları ile ortaya koymaya çalışan birçok çalışma yapılmıştır.

Bunlar arasında, Jeffery A. Borna, David H. Myersa ve William J. Clark'ın yaptığ 1 Trump'ın tweetlerinin borsa hisselerine etkisini ölçen çalışma[80] ve ekonometrik değerlendirme yapan Colonescu'nun çalışmaları örnek olarak verilebilir.

Borna ve diğerleri çalışmalarında sadece Trump'ın başkan seçildiği 8 Kasım 2016 ve başkanlık yemini ettiği 20 Ocak 2017 tarihleri arasında Trump'ın yayınladığı tweetlerinin piyasalar üzerindeki etkilerini incelemişlerdir.

Borna ve diğerleri’ne göre, “ $[k] l s a c a$, Etkin Piyasa Hipotezi, varlık fiyatlarının hızlıca ve bütünüyle yeni enformasyon değerini yansıttı̆̆ını göstermektedir... Ĕger serbest bırakılan bilgi kısmen ya da tamamen tahmin edilmişse, serbest bırakma değeri ilan edilmeden önceki varlık fiyatına dâhil edilebilir... Bununla birlikte, böyle bir durumda, bir olayın onaylanması belirsizliğin çözülmesi nedeniyle fiyatlama üzerinde küçük bir etki yaratabilir. Yeni bilgi içermeyen (örneğin, önceki bir duyurunun tekrarı gibi) kamuya açık ilanlar, rasyonel ve bilgi sahibi yatırımcılar tarafindan göz ardl edilmelidir. Irrasyonel veya bilgisiz yatırımcıların (örneğin, "gürültü tüccarlarl”) eski bilgiler üzerinde harekete geçmesi olasıdır. Gürültü tüccarlarının alım satımı büyükse, rasyonel / profesyonel tüccarların alım satım isteklerine göre, varlık fiyatlarının Etkin Piyasa Hipotezi'nin öngörüsüne uygun olmayan bir şekilde davranması mümkündür. Ayrıca bu gürültüye endeksli alım satım, alım-satım hacmini ve / veya esnekliğini artırabilir. "[81]

Yukarıda yer alan bu analizin doğruladığı gibi, piyasalar özellikle anlık siyasi duyurular, krizler ve benzeri olaylar ile korkak, çekingen veya gürültüye göre reaksiyon veren yatırımcılar tarafından daha fazla olumsuz yönde etkilenebilmektedir. Bu durum ise, şirketlerin piyasa değerlerini 
düşürebilmektedir. Ancak Trump'ın tweetleri sadece belli çapta bilinçli ve rasyonel olmayan yatırımcıları değil aşağıda çalışmada örnekleneceği gibi OPEC gibi dev uluslararası örgütlerin petrol piyasa değerlerini bile sıklıkla olumsuz yönde etkilemiştir.

$\mathrm{Bu}$ çerçeve içinde Colonescu'nun ifadesine göre, “...[b]azı finansal piyasa gözlemciler, Başkan Donald Trump'ın tweet'lerinin bir veya başka bir şirketin hisse fiyatlarında kısa vadeli oynaklık yarattı̆̆ına işaret etmektedirler. Bu băglamda FXCM (2018), geçmişte başkanın tweet'lerinden etkilenen Toyota, Lockheed Martin, Boeing ve General Dynamics gibi şirketleri örnek vermektedir..."[82]

Kasım 2018 yılında Trump'ın uluslararası ve Amerikan ulusal piyasalarını olumsuz yönde etkilediğine ilişkin derin raporlar ve analizler yapan önemli bir borsa işlemcisi olan FXCM şirketi 2017 yilinda bir Amerikan devlet kurumu olan CFTC (Commodity Futures Trading Commission / ABD Emtia Vadeli İşlemler Komisyonu ) tarafından müşterilerine yönelik haksız pozisyon aldığ 1 için işlemleri belli süreliğine askıya alınmış ve 7 milyon Amerikan dolar nispetinde bir cezaya tabii tutulmuştur. [83] Bunun Trump'1 eleştirmenin bir bedeli mi yoksa finansal bir denetim neticesinde ortaya çıkan cezai bir durum mu olduğu ise yorumlara açık kalmıştır.

FXCM'in 2018 raporu kapsamında Trump' in tweetlerinin uluslararası piyasalardaki etkisine Trump’ın 2 Mart 2018 tarihli “Ticaret savaşları kolay ve kazanması kolaydır” ana temalı tweeti örneklerden bir tanesi olarak verilmiştir.

Trump tweetinde "Bir ülke (ABD) fillen iş yaptı̆̆ hemen hemen her ülke ile ticarette milyarlarca dolar kaybediyorsa, ticaret savaşları iyidir ve kazanması da kolaydır. Örneğin, belirli bir ülkeyle birlikte 100 milyar doların altına düştügümüzde ve sevimli oluyorlar ve artık biz de ticaret yapmıyoruz - büyük kazanıyoruz. Bu kolay! [84] ifadelerine yer vermiştir. Hemen büyük bir hızla tüm uluslararası medyanın gündemine oturan bu tweet[85] sonrası açılan New York Borsası (New York Stock Exchange / NYSE)'de faaliyet gösteren ABD'de 1896 yilından beri önemli bir yeri ve 30 büyük Amerikan endüstri kuruluşunun endekslerini yayınlayan Dow Jones Endüstri Ortalaması Endeksi ( the Dow Jones Industrial Average / DJIA) Trump'ın beyanatına olumsuz bir tepki olarak 300 puanlık düşüş ile açılmıştır.

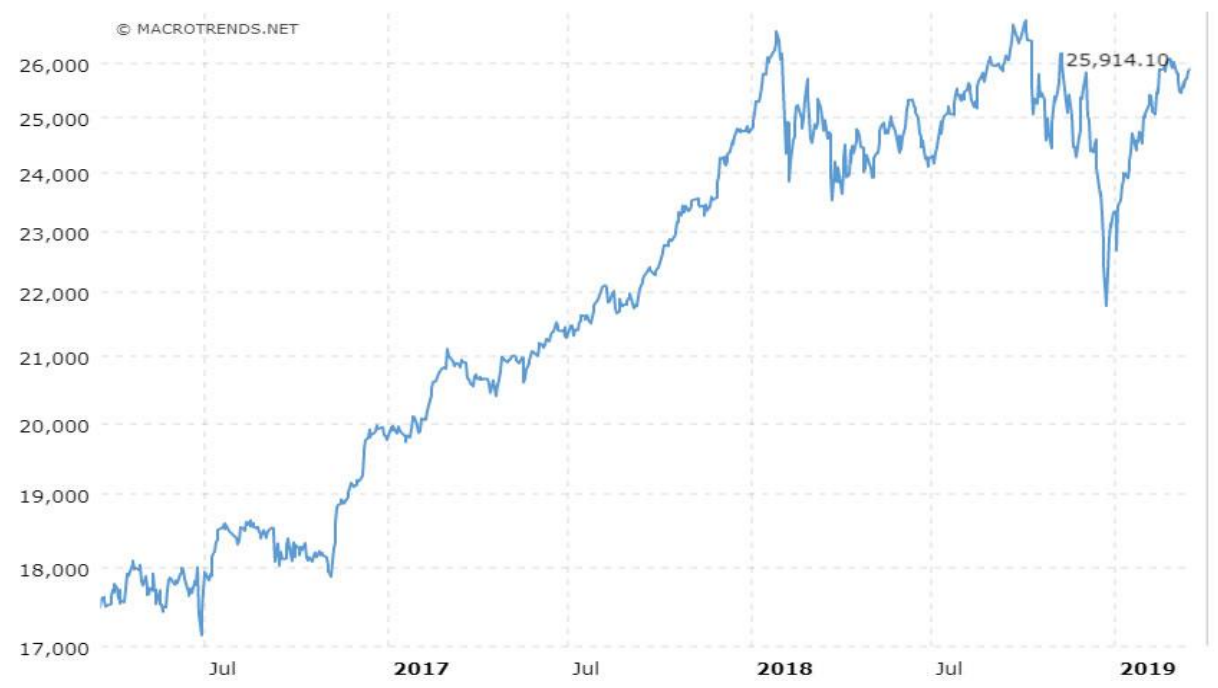

Grafik 1. 21 Mart 2016-18 Mart 2019 Tarihleri Arasında Dow Jones Endüstri Ortalama Endeksi

Kaynak : 21 Mart 2016-18 Mart 2019 periyotları arasındaki endeksler için bkz. Macrotrends, "Dow Jones - 10 Year Daily Chart", https://www.macrotrends.net/1358/dow-jones-industr, erişim tarihi:19 Mart 2019; Endeks 19 Mart 2018 tarihinde 25,914.10 seviyelerinde seyretmektedir.

Oysa 2016 yılı Çin-Amerikan ticari ilişkileri incelendiğinde görüldüğü gibi, Çin ile toplam ABD mal ve hizmet ticareti toplam 648,5 milyar ABD doları olup, yine aynı yıla ilişkin verilerin ortaya koyduğu üzere ABD'nin Çin ile iki yönlü mal ticaret hacmi 578,2 milyar ABD doları civarına[86] ulaşmış iken bu ticaret hacminin 100 milyar doların altına düşeceği duyurusu Trump hükümetinin 
bir ekonomik ve ticari savaş stratejisi olarak algılanmıştır. Endeksin toparlanması ise uzun süre almıştır.

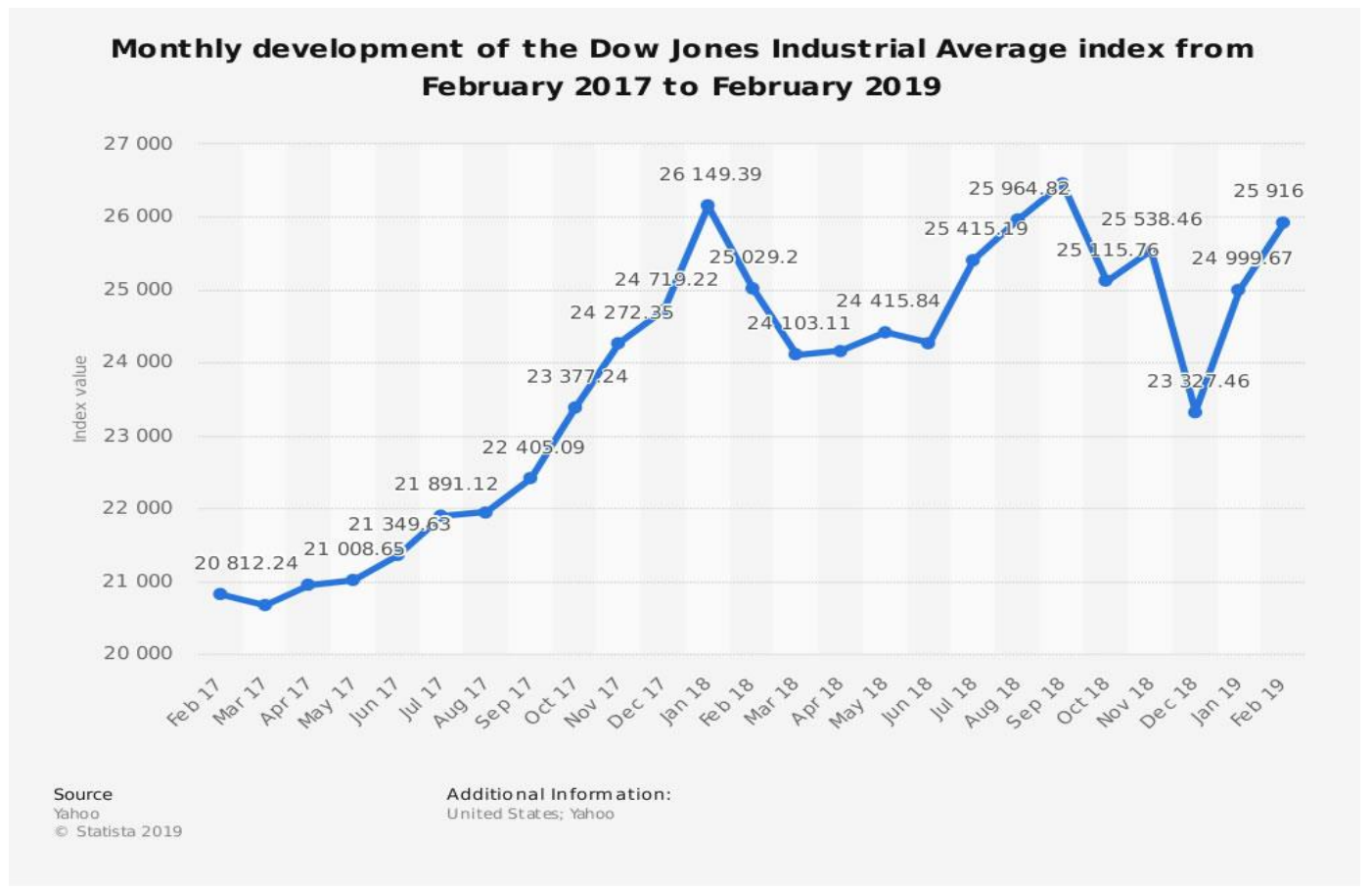

Grafik 2. Şubat 2017- Şubat 2019 Aylık Dow Jones Endüstri Ortalama Endeksi

Kaynak: Statista, "Monthly development of the Dow Jones Industrial Average index from February 2017 to February 2019", https://www.statista.com/statistics/261690/monthlyperformance-of-djia-index/, erişim tarihi:19 Mart 2019

18 Ocak 2018 tarihinde 26,149.39 ve 18 Şubat 2018'de 25,029.2 olan endeks 18 Mart 2018 tarihinde 24,103.11 seviyesine inmiştir. 18 Aralık 2018 tarihinde belirsizler neticesinde 23,327.46 seviyelerine düşen endeks 19 Ocak 2019 tarihinde 24,999.67 ve 19 Mart 2019 tarihinde ise 25,916 seviyesine çıkmıştır.

Trump'ın piyasa üzerinde olumsuz etki yapan 2 Mart 2018 tarihli 272 karakterden oluşan bu beyanatı sonrası, piyasanın normal şartlar göz önüne alındığında ortada o an için bu 600 milyar dolarlık ticaret hacmine yönelik kısa süre içinde bir müdahale öngörmediğine ilişkin sonuç çıkarması neticesinde endeksin kendini toparladığı yönündeki eğilim 1-8 Mart 2018 tarihli endeks verileri incelendiğinde görülmektedir. 


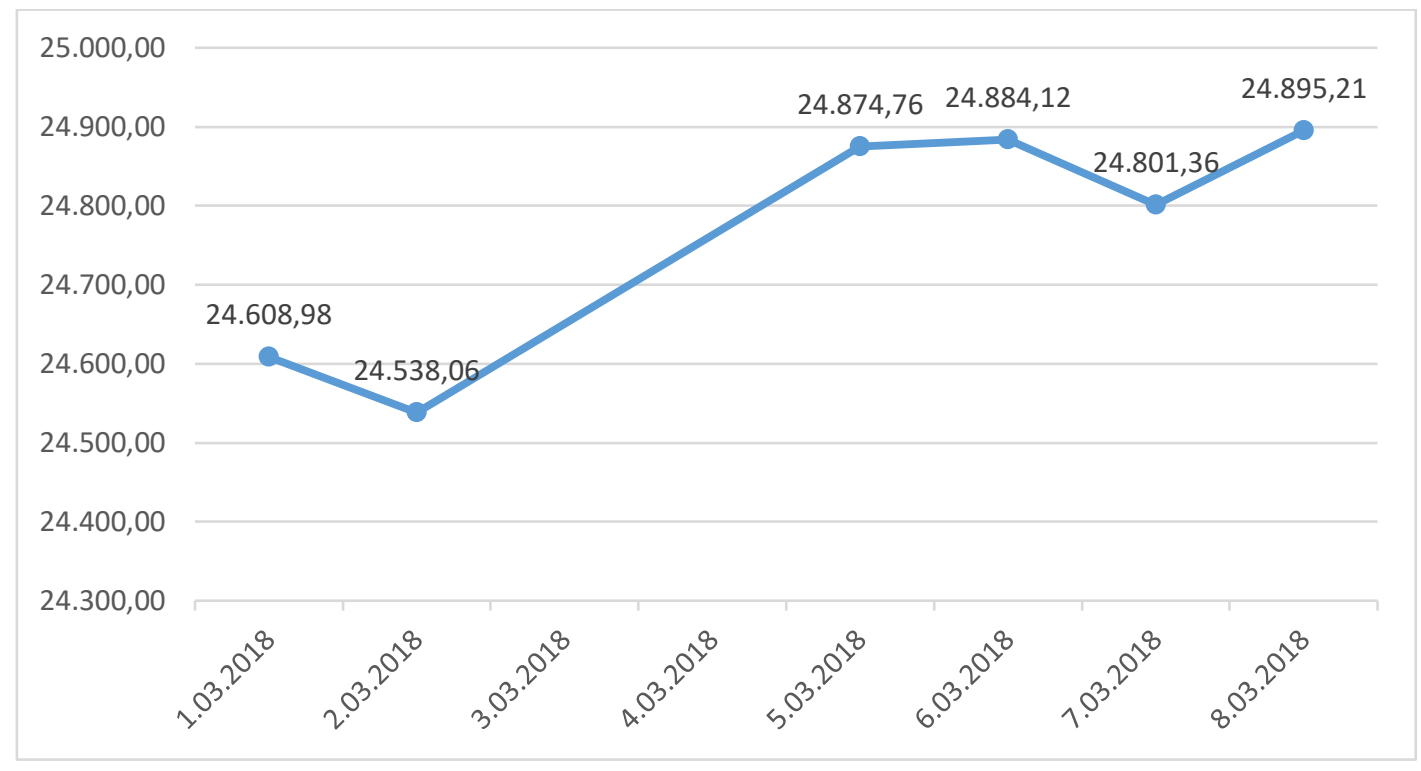

Grafik 3. 1-8 Mart 2018 Tarihli Dow Jones Endüstri Ortalama Endeksi

Kaynak: 21 Mart 2016-18 Mart 2019 periyotları arasındaki endeksler için bkz. Macrotrends, "Dow Jones - 10 Year Daily Chart", https://www.macrotrends.net/1358/dow-jones-industr , erişim tarihi:19.03.2019

Tablo 11'de görüldüğü gibi Trump' in bu tweeti sonrası uluslararası piyasalarda farklı tepkiler ile olumsuz şekilde değer kayıplarının yaşandığı görülmüştür.

Tablo 11.2 Mart 2018 Tarihli Trump Tweeti Sonrası Uluslararası Piyasa Göstergeleri

\begin{tabular}{|lll|}
\hline Ülkeler & Piyasa Endeksi & Kayı Oranı \\
\hline Japonya & Nikkei 225 & $-2.5 \%$ \\
\hline Hong Kong & Hang Seng & $-1.5 \%$ \\
\hline Almanya & CAC 40 & $-2.4 \%$ \\
\hline Birleşik Krallık & DAX & $-2.3 \%$ \\
\hline
\end{tabular}

Kaynak: FXCM, "How Does President Trump’s Twitter Use Impact Forex, Markets And Stocks?", 27 november 2018, https://www.fxcm.com/uk/insights/t/usa/ ;

https://www.fxcm.com/uk/insights/president-trumps-twitter-impact-forex-markets-stocks/ ,erişim tarihi: 21 Mart 2019

Tablo 11 verilerine göre en çok \% -2,5 oranlık kayıp ile Nikkei 225 endeksi etkilenmiştir. Ancak Japon borsasındaki bu kayba rağmen, ekonomisi güçlü olan ülkelerin para piyasalarında görüldüğü gibi, ülke para birimi Yen'in Amerikan doları karşısında sembolikte olsa Mart 2018'de değer kazanmaya başladığ görülmüştür. [87] Tablo 12 incelendiğinde, 1 Ocak 2018 tarihinde 112.602 Yen'den işlem gören 1 ABD doları, 2 Mart 2018 tarihinde 105.749 Yen'den işlem görmeye başlayarak Yen karşısında bir değer kaybı yaşamıştır. Amerikan dolarının Yen karşısında tekrar değer kazanması ise vakit almış ve 20 Mart 2019 tarihinde konjoktürel denge sağlayarak 1 ABD dolar1 110.636 Yen'den işlem görmüştür. 
Tablo 12.1 Ocak 2018 / 2 ve 28 Şubat 2018 / 1-8 Mart 2018 / 20 Mart 2019 Tarihlerinde 1 Yen ve 1 Amerikan Doları Paritesi Karşılaştırılması

\begin{tabular}{|c|c|c|}
\hline Tarih & $\begin{array}{l}\text { 1 Yen / } \\
\text { 1 ABD doları }\end{array}$ & $\begin{array}{l}\text { 1 ABD doları } / \\
\text { 1 Yen }\end{array}$ \\
\hline 1.1 .2018 & 0.00888 & 112.602 .600 \\
\hline 2.1 .2018 & 0.00914 & 109.450 .330 \\
\hline 2.28 .2018 & 0.00938 & 106.629 .490 \\
\hline 3.1 .2018 & 0.00942 & 106.133 .100 \\
\hline 3.2 .2018 & 0.00946 & 105.749 .640 \\
\hline 3.4 .2018 & 0.00947 & 105.608 .620 \\
\hline 3.5 .2018 & 0.00942 & 106.197 .060 \\
\hline 3.6 .2018 & 0.00947 & 105.648 .380 \\
\hline 3.7 .2018 & 0.00942 & 106.128 .370 \\
\hline 3.8 .2018 & 0.00941 & 106.277 .490 \\
\hline 3.20 .2019 & 0.00904 & 110.636 .320 \\
\hline
\end{tabular}

Kaynak: Tablo 12'deki veriler, exchange-rates.org, https://www.exchangerates.org/HistoricalRates/A/JPY/3-20-2019 , erişim tarihi:21 Mart 2019'den elde edilen veriler ile düzenlenmiştir.

Trump'ın tweetleri az gelişmiş ve gelişmekte olan ülkelerde döviz paritesi üzerinde olumsuz etki yaparken, Trump yine aynı şekilde Çin ve Avrupa Birliği ülkelerinin kendi para birimlerini manipüle ettiğini ileri sürmüştür. CBS’nin yoruma göre, “....[b]aşkan Donald Trump, Çin ve Avrupa Birliği'ni mal ve hizmetlerini yabancı alıcılar için daha düşük maliyetli hale getirmek için para birimlerini değiştirmekle suçla [mıştır]... "[88]

Trump bu manipülasyon ile ilgili 20 Temmuz 2018' de paylaştığı tweetinde "Dolar her geçen gün daha fazla değer kazanırken ve ABD oranları arttırmaya devam ederken, Çin, Avrupa Birliği ve diğerleri manipülasyon yolu ile para birimlerini ve faiz oranlarını aşă̆l çekerek, büyük rekabet avantajımızı ortadan kaldırıyor. Her zamanki gibi eşit bir oyun alanı değil ...” [89] analizinde bulunmuştur.

Trump'ın Çin'e karşı başlattığı ticaret savaşına ise Uluslararası Para Fonu (IMF) temkinli yaklaşmıştır. IMF, ABD ve Çin arasındaki bir ticaret savaşının çok riskli olduğunu ve böyle bir savaşın küresel ekonomik düzen içindeki, dünyayı daha fakir ve daha tehlikeli bir yer haline getireceği ikazında bulunmuştur. [90] Trump ticaret savaşında sadece Çin'i değil aynı zamanda Avrupa Birliği ülkeleri ve kuzey komşusu ve NAFTA üyesi Kanada’yı hedef almaktadır. 8-9 Haziran 2018 tarihleri arasında Kanada'nın Quebec eyaletinde La Malbaie beldesinde yapılan 44. G7 toplantısına ilişkin yayınladı̆̆ 1 tweetinde;

“Basın toplantısındaki Justin'ın yanlış beyanatlarına ve Kanada'nın bizim Birleşik Devletlerin tarım üreticilerine, işçilerimize ve şirketlerimize uyguladığ gümrük tarifelerine dayanarak, bizim Amerikalı temsilcilerimize basın bildirisini onaylamamalarını emrettim, çünkü Amerikan piyasasında dolup taşan binek araçlara ilişkin gümrük tarife oranlarını inceleme altına aldık !” [91] ifadelerine yer vermiştir. Trump’ın bu yaklaşımının, ekonomik ve ticari açıdan çok yakın işbirliği içinde bulunduğu ülkelere karşı bile sert kararlar aldığının somut bir örneğini teşkil etmektedir.

Trump' ın piyasaları tedirgin eden yüzlerce tweet arasından diğer bir diğer örnek ise 20 Nisan 2018 tarihinde OPEC petrol fiyatlarını eleştiren tweeti verilebilir. Trump' ın bu tweeti sonrası, piyasalarda petrol fiyatları düşüşe geçmiştir.

ABD'nin köklü yatırım şirketlerinden olan Franklin Templeton Investments'ın analistlerine göre, "Trump cezalandırıcı tarifelere ilişkin tweetler yayınladıkça, ABD hisse senedi endeksleri sık sık düşmekte veya yükselmekte ve tahvil getirileri tipik olarak hareketlenmektedir. Bazen ABD doları 


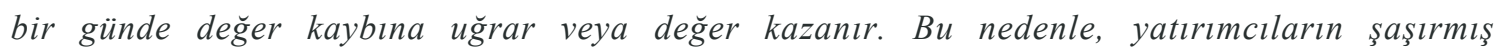
görünmesine şaşılmamalıdır. ” [92]

Franklin Templeton Investments'ın diğer bir analizine göre de, “[m]anşetlerin çokluğuna ră̆men, Trump'ın twitter duyurularının bu yıl küresel borsa performansında -en azından henüz- pek fazla bir etkisi olmadl. Öte yandan, gelişmekte olan bazı piyasa varlık sınıflamaları, özellikle de para birimleri, dünyanın ikinci büyük ekonomisi Çin kazan-kazan tarifeleri ile karşılık verdiğinde dalgalanmaktadır. "[93]

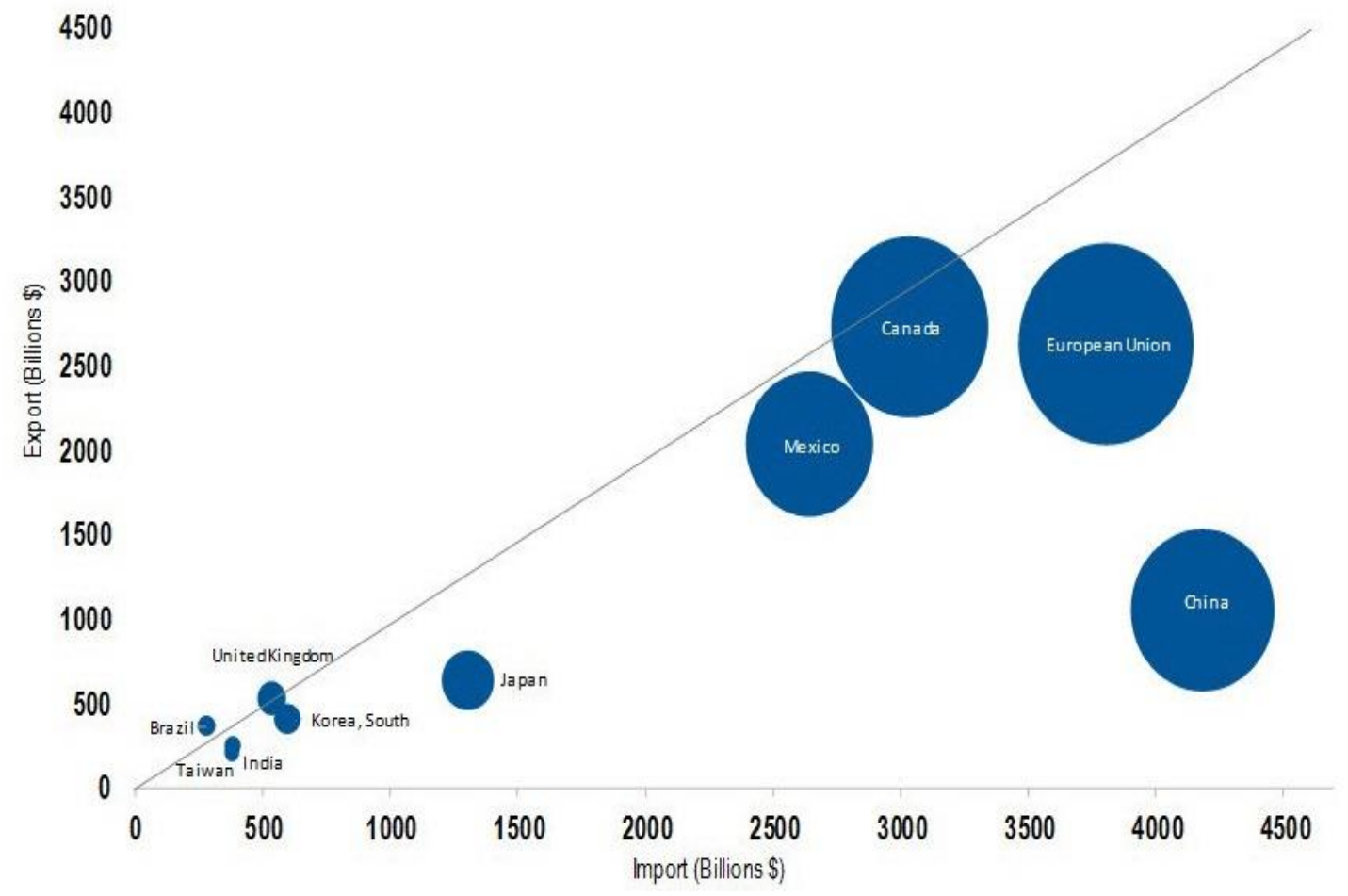

Grafik 4. ABD’nin En Önemli Ticari Ortakları (2008-2017)

Kaynak: U.S Census Bereau'dan aktaran Mattias Hoppe, "Cutting through the Noise: Trump, Trade and Twitter", Advisor $\quad$ Persepectives, 2018 , https://beta.advisorperspectives.com/commentaries/2018/08/02/cutting-through-the-noise-trumptrade-and-twitter?channel=Capital\%20Growth , erişim tarihi: 16 Nisan 2019

Grafik 4’te görüldüğü gibi, ABD'nin en önemli ticari ilişkileri arasında yer alan ülkeler arasında, Kanada, Avrupa Birliği Ülkeleri, Meksika ve Çin yer alırken, yine ikinci derecedeki önem sıralarına göre de, Japonya, Birleşik Krallık, Güney Kore, Brezilya, Hindistan ve Tayvan gelmektedir.

Trump'ın ticari savaşları sadece ithalat ve ihracat ürünlerinin dengelenmesine değil aynı zamanda enerji politikalarına yönelik de gelişmektedir. Trump'ın bu konudaki tweetleri de piyasalarda etki yaratmıştır. Trump özellikle petrol fiyatlarının yüksek olduğunu ileri sürerek özellikle ekonomileri petrol satışına bağlı Rusya'yı ve OPEC ülkelerini hedef almaktadır.

$\mathrm{Bu}$ konuda Trump'ın 20 Nisan 2018 tarihli tweetinde “OPEC'in halen devrede olduğu görülmektedir. Denizlerde tam dolu yük ile seyir halinde olan gemiler de dâhil olmak üzere, hemen her yerde yüksek miktarda petrol tüketimi ile petrol fiyatları suni olarak çok yüksek bulunmaktadır! Bu iyi bir şey olmadığı gibi, kabul de edilemez bir durumdur!" [94] şeklinde yaptığı eleştiri ile piyasaları olumsuz etkilemiştir.

$\mathrm{Bu}$ tweet sonrası DiChristopher'in CNBC'de yayınladığı analize göre, ABD “West Texas Intermediate (WTI) hammadde petrol fiyatları varil fiyatı 68.38 Amerikan dolarından 9 cents 
civarında değer kaybederek 67.50 Amerikan doları seviyelerine gerilemiştir. Yine aynı şekilde önemli bir petrol referans endeksi olan Brent Crude aynı gün 74.07 Amerikan doları seviyesinden 29 cents civarında bir düşme yaşamış ve 72.83 Amerikan doları ile günlük seansı kapatmıştır. [95] Trump' ın OPEC petrol fiyatlarına ilişkin tweetleri aralıklı olarak piyasa istikrarını bozacak şekilde sürmüştür. Trump, 30 Haziran 2018'de petrol fiyatlarının yüksek olması nedeniyle Suudi Arabistan Kralı Salman’ın petrol üretimini iki milyon varile çıkarması gerektiğine ilişkin bir tweet yayınlamıştır.

“Az önce Suudi Arabistan Kralı Salman ile konuştum ve ona, Iran ve Venezüella'daki kargaşa ve işlev bozukluğu nedeniyle, Suudi Arabistan'ın petrol üretimini artırmasını, belki de 2.000.000 varile kadar farkı arttırmasını istiyorum ... Fiyatlar yüksek! Kabul etti!’ [96]

Bu tweet sonrası, bu duruma olumsuz tepki veren piyasalarda petrol fiyatları düşmüştür. Örneğin, New York Mercantile Exchange'de West Texas Intermediate US:CLQ8 kodu ile işlem gören Ağustos vadeli ham petrol \% 0,3 oranında 21 cents düşerek 72.51 ABD dolarından işlem görmüş varil başına 73.94 ABD dolarında sabitlenmiştir. Diğer taraftan, Eylül ayı vadeli UK:LCOU8 brent petrolü 1.93 veya 2,4 ABD doları düşerek 77.30 ABD doları seviyesine inmiştir. [97] Benzer şekilde, Trump söylemleri ile Dow Jones Industrial Average (DJIA) ve S\&P 500 Endeksi (Index SPX)'nde belirgin düşmeler yaşanmıştır. [98]

Trump, 20 Eylül 2018 tarihinde OPEC'i ve petrol fiyatlarını eleştiren bir tweet daha yayınlamıştır. Trump'ın 20 Eylül 2018 tarihli tweetinde "Orta Doğu ülkelerini koruyoruz, biz olmadan onlar uzun süre güvende olmazlard, ancak daha yukarl daha yukarl yükselterek yüksek petrol fiyatlarl için baskı yapmaya devam ediyorlar! Bunu unutmayacă̆ı. OPEC tekeli şimdi fiyatları aşağıya çekmek zorundadır!” [99] analizine yer vermiştir. Bloomberg’ten Denning bu tweeti sonras1 Trump'ın tweetlerinin piyasalarda korku ve kayg1 yarattığını belirtmiştir. [100]

Trump OPEC petrol fiyatlarını eleştiren farklı bir tweetini 25 Şubat 2019 tarihinde yayınlamıştır. 25 Şubat 2019 tarihli tweetinde Trump; "Petrol fiyatları çok yükseliyor. OPEC, lütfen rahatla ve sakin ol. Dünya fiyat zammını kaldıramaz. Kırılgandır!" [101] ifadelerine yer verdikten sonra, petrol fiyatları 2019 yılının ilk aylarındaki en büyük düşüşünü yaşamıştır. West Texas Intermediate (WTI) \% 3 ve Brent Crude 2.03 Amerikan doları seviyesine düşmüştür. [102] Brent petrol fiyatları üzerindeki düşüşler aynı zamanda Brent petrol fiyatlarına bağlı olan uluslararası altın fiyatlarını da doğal olarak etkilemektedir. 25 Şubat 2019'da Brent petrol düşünce, altın fiyatı da, \% 14 oranında 1.83 düşüş ile 1.327,37 Amerikan doları seviyesine inmiş [103] ancak 26 Şubat 2019 tarihinde piyasanın \% 0.29 oranında tekrar toparlanması ile 3.87 artış ile 1.327.86 Amerikan doları seviyesine çıkmıştır. [104] Bir bakıma, Brent petrol fiyatları aşağı veya yukarı eğilimde altın fiyatlarını etkilediği gibi, gelişmekte olan ülkelerin döviz rezervleri altına bağlı olduğundan doğal olarak ülkelerin döviz kurları da dalgalanma yaşamaktadır. Bu durum ise, hisse senetlerine, borsaya ve tüketim fiyat endekslerine de olumsuz etki yapabilmektedir. Ancak Trump'ın uluslararası piyasalarının istikrarına yönelik bir kaygı taşımadığı görülmektedir. Bir anlamda, Trump'1 yakından takip eden ve analizlerine göre pozisyon koruyan ve strateji uygulayan uluslararası piyasa şirketleri ve simsarlar Trump'ın krizlerinden doğal olarak kazanç elde etmektedirler. Bir anlamda Trump tweetleri bir kesimin zarar etmesine neden olurken diğer taraftan diğer bir kesimin kâr elde etmesine dolaylı veya dolaysız imkân sağlamaktadır.

Trump, 25 Şubat 2019'da yayınladığ 1 ve petrol fiyatlarına manipülatif etki eden tweetinden sonra 22 Nisan 2019'da petrol piyasalarında \%2,5'luk bir fiyat düşüşüne neden olan başka bir tweet yayınlamıştır. [105] Oysa Mart ayında Suudi Arabistan’ın başını çektiği ve OPEC ve OPEC üyesi olmayan petrol ihraç eden ülkelerin \% -450 ve \% +150 arasında petrol üretimi kesinti uyum sözleşmesine uydukları gözlenmiştir. [106] Petrol üretimlerini azaltan OPEC ve diğer ülkeler Trump' in 22 Nisan 2019 tweeti sonrası ayrıca hem az üretim hem de \% 2,5 fiyat düşüşü ile olumsuz yönde etkilenmişlerdir.[107]

Trump'ın 22 Nisan 2019 tarihli tweetinde ; "Suudi Arabistan ve OPEC'deki diğerleri, şu an bizim bir bütün halinde Iran Petrolüne yönelik uyguladı̆̆ımız yaptırımlara karşı bir petrol akışı farkı oluşturmaktan daha fazlasını yapmak zorundadırlar. @JoKKerry ve ona ABD'yi Logan Yasası'nın çok büyük ihlali olan Iran Nükleer müzakerelerinde yanlış yönlendirilmesine yardım edenler tarafından İan (başlı başına) çok kötü bir tavsiyeyi temsil etmektedir.” [108] görüşlerine yer vermiştir. 


\section{Twitter Diplomasi ile Gündem Oluşturma Örneği: ABD Büyükelçiliğinin Kudüs'e Taşınması Kararı}

Trump'ın 6 Aralık 2017 tarihinde Twitter üzerinden açıklama yaparak, ABD İsrail Büyükelçiliği’nin Kudüs'e taşınması ve de jure olarak ABD’nin Kudüs'ü İsrail'in başkenti olarak tanıması Twitter'ın diplomatik misyonunda kullanılmasını fiilen başlatmıştır. [109]

“Kudüs'ün resmen İsrail'in başkenti olarak tanımanın zamanının geldiğini belirttim. Ayrıca Dışişleri Bakanlığı'nı, Amerikan Elçiliğini Tel Aviv'den Kudüs'e taşımaya hazırlanıyor. ” [110]

Trump'ın tekrardan gündeme getirdiği bu konu daha önce Amerikan Kongresine 1995 yılında sunulmuş ve Temsilciler Meclisi ve Senato tarafindan 31 Mayıs 1999 tarihine kadar uygulanması gerektiği hususunda onaylanmış olan “1995 Kudüs Büyükelçiliği Kanunu[111] (Jerusalem Embassy Act of 1995)” idi. Trump bir bakıma 1995 yılında onaylanmış olan ve daha önceki meslektaşlarının uluslararası çekinceler dolayısıyla imzalamaktan kaçındığ bu kanunu 18 yıl aradan sonra 6 Aralık 2017'de birden gündeme getirmiş ve başkanlık onayı ile uygulamaya koymuştur. [112]

Doğal olarak gündemi değişmesine katkı sağlayan, Trump'ın bu kararı Cumhuriyetçi senatörler tarafindan da desteklenmiştir. Trump, senatör Chuck Grassley'in tweetini retweet ederek, kendisine yapılan desteği hemen paylaşmıştır.

Senatör Grassley 6 Aralık 2017 tarihli tweetinde “95 sayılı Kudüs Büyükelçiliği Yasası (Senato 93'e karşı 5 oyu kullanırken ben de lehte oy kullanmıştım), büyükelçiliğin 31 Mayıs 1999'a kadar Kudüs'te olması gerektiğini belirtmekteydi. 18 yll boyunca Cumhuriyetçi ve Demokrat başkanları bu kararı uygulamadılar. Bunu yapmak için harekete geçen Trump'a tebrikler. Amin!!!!” [113] diyerek Trump'ın y1llar sonra diğer ABD başkanlarından farklı bir şekilde hareket etmesine destek vermiştir.

Başkan seçildikten sonra Rusya'nın ABD başkanlık seçimlerinin Trump lehinde manipüle edildiğine dair yoğun bir medya gündemi sonrası[114], Trump 6 Aralık 2017 tarihinde almış olduğu bu karar ile gündemi kendi lehinde yönlendirerek değişmesini sağlamıştır. [115] Trump'ın bu kararı resmi olarak alınmış bir karar olduğundan Twitter'ın dışında ayrıca Beyaz Saray duyurusu olarak da yayınlanmıştır. [116] Dünyadaki uluslararası tepkiler bu kararın geri alınması yönünde olmasına rağmen 14 Mayıs 2018 tarihinde ABD büyükelçiliği Kudüs’te resmen açılmış ve faaliyete geçmiştir.

Trump 14 Mayıs 2018 tarihinde “Kudüs'teki ABD Büyükelçiliği açılışı@FoxNews \& @FoxBusiness'da canlı olarak yayınlanacaktır. Doğu saati ile sabah 9: 00'da çoktan etkinlik başlamış olacaktır. Gün İsrail için büyük bir gündür!’ [117] tweeti ile ABD büyükelçiliğinin Kudüs’teki açılışını uluslararası ve Amerikan ulusal kamuoyuna duyurmuştur.

Tablo 13. Trump'ın tweetlerinin piyasalara olan etkisini öne çıkaran Google arama motorunda rastgele seçilmiş haber başlıkları ( 2017-2019) [118]

\begin{tabular}{|c|c|c|c|}
\hline Haber Kaynağı & Tarih & Haber Başlığının Aslı & Haber Başlığının Türkçesi \\
\hline Fortune[119] & 6 Haziran & $\begin{array}{c}\text { Trump Plans to Keep } \\
\text { Tweeting Regardless of the } \\
\text { Media's Response }\end{array}$ & $\begin{array}{c}\text { Trump Medya'nın cevabına } \\
\text { aldırış etmeden tweet } \\
\text { yayınlamaya devam etmeyi } \\
\text { planlamaktadır }\end{array}$ \\
\hline USA Today[120] & 1 Ocak & $\begin{array}{c}\text { President Trump's } \\
\text { ambitious agenda: 7 things } \\
\text { to watch in 2018 }\end{array}$ & $\begin{array}{c}\text { Başkan Trump'ın iddialı } \\
\text { gündemi: 2018'de izlenecek 7 } \\
\text { şey }\end{array}$ \\
\hline Time[121] & 2018 & $\begin{array}{c}\text { Donald Trump Says Trade } \\
\text { Wars Are 'Good and Easy } \\
\text { to Win' }\end{array}$ & $\begin{array}{c}\text { Donald Trump, Ticaret Savaşları } \\
\text { Güzel ve Kazanmasının Kolay } \\
\text { Olduğunu Söylemektedir }\end{array}$ \\
\hline The Washington & 2 Nisan & $\begin{array}{c}\text { How Washington is } \\
\text { undermining the stock } \\
\text { Porket's highest-flying sector }\end{array}$ & $\begin{array}{c}\text { Washington Borsa'nın en çok } \\
\text { yükselen sektörüne nasıl zarar } \\
\text { veriyor }\end{array}$ \\
\hline CNBC[123] & 2018 & $\begin{array}{c}\text { US crude ticks up 9 cents, } \\
\text { settling at \$68.38, as } \\
\text { market shakes off Trump's } \\
\text { attack on OPEC }\end{array}$ & $\begin{array}{c}\text { ABD ham petrolü, piyasanın } \\
\text { Trump'ın OPEC saldırısını } \\
\text { bertaraf ettiğinden beri 9 cent }\end{array}$ \\
\hline
\end{tabular}




\begin{tabular}{|c|c|c|c|}
\hline & & & $\begin{array}{l}\text { gerileyerek } 68,38 \text { Amerikan } \\
\text { dolar1 seviyesine gelmiştir }\end{array}$ \\
\hline ВBC[124] & $\begin{array}{l}11 \text { Haziran } \\
2018\end{array}$ & $\begin{array}{l}\text { G7: Fact checking Trump's } \\
\text { tweets about trade }\end{array}$ & $\begin{array}{l}\text { G7: Trump'in ticaret ile ilgili } \\
\text { tweetlerini doğrulayan olay }\end{array}$ \\
\hline Market Watch[125] & $\begin{array}{l}30 \text { Haziran } \\
2018\end{array}$ & $\begin{array}{l}\text { Trump says Saudi Arabia } \\
\text { agreed to raise oil output by } \\
\text { 'maybe up to' } 2 \text { million } \\
\text { barrels a day }\end{array}$ & $\begin{array}{c}\text { Trump, Suudi Arabistan'ın petrol } \\
\text { üretimini günde belki } 2 \text { milyon } \\
\text { varile kadar yükseltmeyi kabul } \\
\text { ettiğini söyledi }\end{array}$ \\
\hline Market Watch[126] & $\begin{array}{l}2 \text { Temmuz } \\
2018\end{array}$ & $\begin{array}{l}\text { U.S. oil prices slip, but global } \\
\text { prices sink as traders fret } \\
\text { over potential for higher } \\
\text { output }\end{array}$ & $\begin{array}{l}\text { Amerikan petrol fiyatları } \\
\text { düşüyor, fakat küresel fiyatlar da } \\
\text { düşerken tüccarlar, üretimin artış } \\
\text { yaratma potansiyeli üzerinde } \\
\text { endişeleniyorlar }\end{array}$ \\
\hline Bloomberg[127] & $\begin{array}{l}5 \text { Temmuz } \\
2018\end{array}$ & $\begin{array}{l}\text { Tehran Taunts Trump, } \\
\text { Telling Him His Tweets } \\
\text { Drive Up Oil Prices }\end{array}$ & $\begin{array}{l}\text { Tahran, tweetleri ile petrol } \\
\text { fiyatlarını yukarı çektiğini } \\
\text { söyleyerek Trump ile dalga } \\
\text { geçiyor }\end{array}$ \\
\hline The Guardian[128] & $\begin{array}{c}11 \\
\text { Temmuz } \\
2018\end{array}$ & $\begin{array}{l}\text { Markets rattled as Trump } \\
\text { escalates China trade war } \\
\text { with tariffs on } \$ 200 \mathrm{bn} \text { of } \\
\text { imports -as it happened }\end{array}$ & $\begin{array}{c}\text { Trump'ın, Çin ticaret savaşıını } \\
200 \text { milyar dolarlık ithalat } \\
\text { vergileriyle yükseltmesiyle } \\
\text { piyasalar sarsıldı }\end{array}$ \\
\hline CBS[129] & $\begin{array}{c}20 \\
\text { Temmuz } \\
2018\end{array}$ & $\begin{array}{c}\text { Trump says China, EU } \\
\text { "manipulating their } \\
\text { currencies" -- and U.S. dollar } \\
\text { hit }\end{array}$ & $\begin{array}{c}\text { Trump, Çin'in AB'nin "para } \\
\text { birimlerini manipüle ettiğini" - } \\
\text { ve ABD dolarını vurduğunu } \\
\text { söyledi }\end{array}$ \\
\hline Bloomberg[130] & $\begin{array}{l}20 \text { Eylül } \\
2018\end{array}$ & $\begin{array}{l}\text { Trump's OPEC Tweets Mix } \\
\text { Fear and Delusion }\end{array}$ & $\begin{array}{l}\text { Trump’ın OPEC tweetleri korku } \\
\text { ve düş kırıklığı yaratmaktadır }\end{array}$ \\
\hline $\mathrm{BBC}[131]$ & $\begin{array}{l}9 \text { Ekim } \\
2018\end{array}$ & $\begin{array}{l}\text { US trade war would make } \\
\text { world 'poorer and more } \\
\text { dangerous' }\end{array}$ & $\begin{array}{l}\text { Amerikan ticaret savaşı Dünya’yı } \\
\text { daha fakir ve tehlikeli yapacaktır }\end{array}$ \\
\hline Bloomberg[132] & $\begin{array}{l}26 \text { Ekim } \\
2018\end{array}$ & $\begin{array}{l}\text { Trump Is Now Bad for the } \\
\text { Stock Market }\end{array}$ & $\begin{array}{c}\text { Trump artık borsa için zararlı } \\
\text { olmaya başladı }\end{array}$ \\
\hline Skrill[133] & $\begin{array}{l}6 \text { Kasım } \\
2018\end{array}$ & $\begin{array}{c}\text { Investing in the USD: How } \\
\text { Trump affects the dollar's } \\
\text { strength }\end{array}$ & $\begin{array}{l}\text { ABD dolarına Yatırım: Trump } \\
\text { Doların Gücünü Nasıl Etkiliyor }\end{array}$ \\
\hline Express[134] & $\begin{array}{l}21 \text { Kasim } \\
2018\end{array}$ & $\begin{array}{l}\text { Trump MOCKS Saudi } \\
\text { Arabia in brutal tweet and } \\
\text { declares 'THANKS' for } \\
\text { driving down oil price }\end{array}$ & $\begin{array}{l}\text { Trump, Suudi Arabistan ile kaba } \\
\text { tweeti ile alay ediyor ve petrol } \\
\text { fiyatlarını aşağıya çektiği için } \\
\text { teşekkür ettiğini bildiriyor }\end{array}$ \\
\hline FXCM[135] & $\begin{array}{c}27 \text { Kasim } \\
2018\end{array}$ & $\begin{array}{l}\text { How Does President Trump's } \\
\text { Twitter Use Impact Forex, } \\
\text { Markets And Stocks? }\end{array}$ & $\begin{array}{l}\text { Başkan Trump'ın Twitter } \\
\text { Kullanımı Forex, Piyasa ve } \\
\text { Borsa'yı Nasıl Etkilemektedir? }\end{array}$ \\
\hline $\begin{array}{c}\text { The New York } \\
\text { Times[136] }\end{array}$ & $\begin{array}{l}8 \text { Aralık } \\
2018\end{array}$ & $\begin{array}{l}\text { Prosecutors Effectively } \\
\text { Accuse Trump of } \\
\text { Defrauding Voters. What } \\
\text { Does It Mean? }\end{array}$ & $\begin{array}{l}\text { Savcılar, Trump'1 etkili bir } \\
\text { biçimde seçmenleri aldatmak ile } \\
\text { suçluyorlar. Bu ne anlama } \\
\text { gelmektedir? }\end{array}$ \\
\hline $\begin{array}{c}\text { The Telegraph } \\
\text { [137] }\end{array}$ & $\begin{array}{l}9 \text { Aralik } \\
2018\end{array}$ & $\begin{array}{l}\text { Siege politics as Democrats } \\
\text { say Donald Trump could face } \\
\text { prison over hush payments }\end{array}$ & $\begin{array}{l}\text { Kuşatma politikası, Demokratlar } \\
\text { Trump'in bu susturma amaçlı } \\
\text { para ödemesinden dolayı hapis } \\
\text { cezası ile karşı karşıya } \\
\text { kalabileceğini söylüyorlar }\end{array}$ \\
\hline
\end{tabular}




\begin{tabular}{|c|c|c|c|}
\hline $\begin{array}{c}\text { The Wall Street } \\
\text { Journal[138] }\end{array}$ & $\begin{array}{c}14 \text { Aralik } \\
2018\end{array}$ & $\begin{array}{c}\text { Cohen Describes Trump's } \\
\text { Involvement in Hush-Money } \\
\text { Payments }\end{array}$ & $\begin{array}{c}\text { Cohen Trump'ın susturma amaçlı } \\
\text { ödeme işine karışmasını } \\
\text { tanımlıyor }\end{array}$ \\
\hline CNN[139] & $\begin{array}{l}21 \text { Aralik } \\
2018\end{array}$ & $\begin{array}{c}\text { Trump's erratic behavior was } \\
\text { background noise for } \\
\text { markets. Not anymore }\end{array}$ & $\begin{array}{l}\text { Trump'ın başıboş davranışı } \\
\text { piyasalar için arka planda gürültü } \\
\text { idi. Artık şimdi değil. }\end{array}$ \\
\hline $\begin{array}{l}\text { Washington } \\
\text { Post[140] }\end{array}$ & $\begin{array}{c}7 \text { Ocak } \\
2019\end{array}$ & $\begin{array}{l}\text { Is Donald Trump losing } \\
\text { his agenda-setting power? }\end{array}$ & $\begin{array}{l}\text { Donald Trump gündem belirleme } \\
\text { gücünü kayıp mı ediyor? }\end{array}$ \\
\hline CNBC[141] & $\begin{array}{c}25 \text { Şubat } \\
2019\end{array}$ & $\begin{array}{c}\text { Oil sinks more than } 3 \text { percent } \\
\text { after Trump tells OPEC } \\
\text { prices are too high }\end{array}$ & $\begin{array}{c}\text { Trump, OPEC fiyatları çok } \\
\text { yüksek dedikten sonra yüzde } \\
\text { 3'ten fazla düştü }\end{array}$ \\
\hline IG[142] & $\begin{array}{c}26 \text { Şubat } \\
2019\end{array}$ & $\begin{array}{l}\text { Oil prices fall } 3 \% \text { after } \\
\text { Trump tweets about high } \\
\text { prices }\end{array}$ & $\begin{array}{c}\text { Trump'ın yüksek fiyata ilişkin } \\
\text { tweetleri sonrası petrol fiyatları } \\
\% 3 \text { düştü }\end{array}$ \\
\hline Politico[143] & $\begin{array}{l}22 \text { Nisan } \\
2019\end{array}$ & $\begin{array}{c}\text { A threat in Trump's back } \\
\text { pocket: Shaking up the global } \\
\text { oil industry }\end{array}$ & $\begin{array}{c}\text { Trump'in arka cebinde duran bir } \\
\text { tehdit: Küresel petrol endüstrisini } \\
\text { sarsiyor }\end{array}$ \\
\hline
\end{tabular}

\section{Trump'ın Golan'ın ilhakını onaylayan tweetlerinin analizi}

ABD Temsilciler Meclisi ve Senatosu'nun onayladığg “1995 Kudüs Büyükelçiliği” [144] yasasını 6 Aralık 2017'de imzalayarak yürürlüğe koyan ve uluslararası alanda Avrupa Birliği ve İslam ülkelerinden eleştirilere maruz kalan bu o kararını da Twitter üzerinden yayınladığı tweetler ile açıklayan Trump[145] yine benzer şekilde Golan Tepeleri ile ilgili radikal bir kararı aynı şekilde yayınladığı tweet ile duyurmuştur. Piyasalar ile doğrudan ilgisi olmasa da uluslararası ilişkiler ve Orta-Doğu'nun uluslararası bölge güvenliği açısından haber değeri olan Trump'ın Golan'ın İsrail tarafından 1981 yılında almış olduğu tek taraflı ilhak kararını tanıması da önem arz etmektedir. Trump twitter diplomasisi ile ABD dış politikasının ilk önce yayınladığı tweetler ile açıklamış ve sonrasında ise adı yolsuzluk iddiaları ile İsrail iç politikasında yoğun baskı altında olan Netanyahu ile Beyaz Saray’da 25 Mart 2019 tarihinde basına açık gerçekleşen toplantıda resmi olarak ABD tarafından 1982'de veto edilen[146] Birleşmiş Milletler Güvenlik Konseyi'nin 17 Aralık 1981 tarihli S/RES/497 sayılı kararına[147] rağmen herhangi bir diplomatik çekince de bulunmadan 38 yıl sonra tanımıştır.

Trump'ın 21 Mart 2019 tarihinde yayınladığı; “52 yıl sonra, Birleşik Devletler için İsrail devletinin ve bölge güvenliliğinin kritik stratejik ve güvenlik önemi olan Golan Tepeleri üzerindeki İsrail egemenliğini tam olarak tanıma zamanıdır. [148] tweeti ile İsrail'e destek politikasını açık bir şekilde açıklamıştır.

Trump'ın ABD'nin ilhak kararını onayladığı ve Netanyahu ve Beyaz Saray'a mansiyon yaptığı 25 Mart 2019 tarihli toplantıya ilişkin tweet de; "Bugün, Ísrail başbakanı Netanyahu'ya Golan tepeleri üzerinde Israil'in egemenliğini tanıyan başkanlık bildirisini imzaladı̆̆ım Beyaz Saray'da karşılamaktan büyük onur duymaktayım." [149] ifadelerine yer vererek 26 Mart 2019 tarihindeki tweet sadece Trump ve Netanyahu'nun ABD başkanlık onay belgesinin ve iki liderin birlikte yer aldığı bir fotoğraf karesinde "İsrail devletinin bir parçası olan Golan Tepeleri’nin tanınma bildirisi” notu ile yayınlanmıştır. [150] Trump bu tweette ayrıca ABD’nin ilhak kararını gerekçelendiren bir metine de yer vermiştir. [151] Trump'ın imzaladığ1 gerekçeli ilhak onay bildirisinde, İsrail'in 1967 Arap-İsrail savaşında askeri güç ile işgal ettiği toprak için "İsrail' in 1967 'de kontrol altına aldığ 1 Golan tepeleri 'ifadesini kullanmıştır. [152] Aynı ifadeler ve "işgal" kelimesi yerine "zapt" kelimesi the Washington Post ve benzer Amerikan gazeteleri tarafindan da kullanılmıştır. Örneğin the Washington Post yazarı Adam Taylor bu haberi "Hiçbir başkan Golan Tepeleri'nin İsrail tarafından kontrol edilmesini tanımadı. Trump bunu bir tweet ile yaptı" manşeti ile duyurmuştur. [153]

\section{Sonuç}

$\mathrm{Bu}$ çalışmada, gündem oluşturmanın siyasal iletişimde önemli olduğu ve yeni medya uygulaması olan Twitter'ın Trump'ın özellikle haber gündemi oluşturma stratejisi içinde bir siyasi bir iletişim ve manevra aracı olarak kullanıldığı somut örnekler ile görülmektedir. Trump'ın uluslararası konularda aldığı radikal kararlarını öncelikle Twitter üzerinden açıklaması, günümüzde Trump dönemine kadar uluslararası diplomaside alışık olunmayan Twitter'ın üzerinden “diplomasi” kavramının çeşitli diplomatik kanallardan seslendirilen itirazlara rağmen yaygın bir şekilde kanıksanmasını da sağlamıştır. Trump'ın diplomatik araç 
olarak kullandığı Twitter üzerinden yayınladığı tweetlerin uluslararası piyasaları kısa süreli de olsa etkilemesi ve fiyat dalgalanmaları yaratması Trump'ın sadece haber gündemi konularının bir "aktör" ve "özne" sıfatıyla merkezine oturtmadığı aynı zamanda da bir "faktör" rolü oynayarak baskı ve etki gücü yarattığı söylenebilir. Trump'ın tweetleri sonrasında incelenen piyasa verilerindeki değişimim bu durumu açık bir şekilde desteklemektedir. Literatür araştırması sonucu elde edilen diğer bir sonuç ise, Trump'ın Twitter üzerinden kişi, kurum ve kuruluşlar üzerinde ulusal ve uluslararası boyutta sahip olduğu etki gücünün kendi karizmatik şahsiyetinden ziyade Amerika Birleşik Devletleri başkanlık makamından elde edildiğidir.

\section{Bilgilendirme}

*Bu makale Bülend Aydın Ertekin tarafından, "Uluslararası Güvenlik Açısından ABD Başkanı Donald Trump'ın Twitter Diplomasisinin ve Twitter Diplomasi Kavramının Değerlendirilmesi / The Evaluation of Twitter Diplomacy of the President of the United States Donald Trump and of the Concept of Twitter Diplomacy From the Point of View of International Security”, başliğ ile International Congress of Energy, Economy and Security / Enscon18 Etkinlik Tarihi: 21.04.2018 - 22.04.2018'de sunulan özet bildiri konusundan esinlenerek yazllan yeni bir çallşmadır.

\section{Referanslar}

[1]. Mass Media, "Agenda Setting Theory: The Creation of what the public thinks is important", University of Twente, https://www.utwente.nl/en/bms/communication-theories/sorted-bycluster/Mass-Media/Agenda-Setting_Theory/ , erişim tarihi: 30 Aralık 2018

[2]. Melek, Gizem. (2017). "Medya Arası Gündem Belirleme Kuramı Araştırmalarında Bir Yöntem Uygulaması: Hürriyet Online ve Twitter Örneği", İlet Dergisi, Bahar, Nisan 2017, s126 (123-148), file:///D:/yeni\%20CALISMA/6-Medya-Arasi-Gundem.pdf, erişim tarihi: 30 Aralık 2018

[3]. Şekil 1 PÜKO döngüsünden esinlenilmiştir.

[ ${ }^{4}$ ]. İmai, Masaaki. (1994). Kazien, Brisa, s.59,

[5]. Şekil 2, İmai, Masaaki. (1994). Kazien, Brisa, s.59, Şekil 3.9’dan esinlenilmiştir.

[6]. Nasıl ki, bir spor rekabetinde seyirci desteği önem arz ediyorsa bu kez de, liderler ve medya arasındaki ikili denkleme, izleyici konumunda olan üçüncü bir aktör olan, medya takipçileri rol almaktadır. Medya takipçilerinin de bu siyasi faaliyete katılmaları ile karşımıza birbirini tamamlayan bir üçgen modelini yaratmaktadır. Günümüzde, özellikle Twitter’ın öneminden bahsederken, bu üçgen modellemesinde, üçgenin lider kenar açısının genişliğine göre bu kenardan beslenen medya kenar çizgisi uzun yani önemli veya kısa yani sınırlı etki gücüne sahip olabilir. Yine aynı şekilde, bu üçgenin takipçi kenarı ise bir bakıma bu üçgenin alan genişliğinin ölçülmesinde algı yaratma açısından etkinlik sahibidir.

[ $\left.{ }^{7}\right]$. Bkz. Cohen, Bernard.(2004). The Press and Foreign Policy, Princeton, N.J.: Princeton University Press, s.13'den aktaran.Kinder, Donald R (2004). "Pale Democracy: Opinion and Action in Postwar America", [The Evolution of Political Knowledge: Theory and Inquiry in American Politics (Edited by.Mansfield, Edward D - Sisson, Richard)], (2004)/ The Ohio University Press, (104-158), s.119; Cümlenin İngilizcesi "The press may not be successful much of the time in telling people what to think, but it is stunningly successful in telling its readers what to think about." şeklindedir.

$\left.{ }^{8}\right]$. Bu yorum; Gündem Belirleme Teorisi, kamuoyunun gücü ve İçerik Analizi yönteminin önemi bağlamında ele alınan bir çıkarsamadır.

[9]. Bkz McCombs, Maxmell. (2014). Setting The Agenda, 2nd Edition, Polity Press 
$\left.{ }^{10}\right]$. McCombs, Maxmell . (2014). Setting The Agenda, 2nd Edition, Polity Press, s.24

[11]. McCombs, Maxmell. (2014). Setting The Agenda, 2nd Edition, Polity Press, 2014, s.24 ; Ayrica bkz. Lippmann, Walter.(1922) Public Opinion, https://wwnorton.com/college/history/americaessential-learning/docs/WLippmann-Public_Opinion-1922.pdf, erişim tarihi : 22 Ocak 2019; Bkz. Lippman, Walter . (1922). Public Opinion (With a New Introduction by Michael Curtis), Transaction Publishers, New Brunswick (U.S.A), Originally published in 1922, Second Printing, 1998,s.xvii, https://monoskop.org/images/b/bf/Lippman_Walter_Public_Opinion.pdf , erişim tarihi:20 Ocak 2019

$\left.{ }^{12}\right]$. Türkçe’ye "sözde çevre" veya" yalancı çevre/ ortam” şeklinde de çevrilmektedir.

[13]. Lippmann, Walter. (1922). Public Opinion (With a New Introduction by Michael Curtis), Transaction Publishers, New Brunswick (U.S.A), Originally published in 1922, Second Printing, 1998,s.xvii, https://monoskop.org/images/b/bf/Lippman_Walter_Public_Opinion.pdf ， s.xviii, erişim tarihi:20 Ocak 2019

$\left.{ }^{14}\right]$. McCombs, Maxmell . (2014). Setting The Agenda, 2nd Edition, Polity Press, s.24

$\left.{ }^{[15}\right]$. McCombs, Maxmell. (2014). Setting The Agenda, 2nd Edition, Polity Press, s. 24

$\left.{ }^{16}\right]$. Lippmann, Walter .(1922). Public Opinion, https://wwnorton.com/college/history/americaessential-learning/docs/WLippmann-Public_Opinion-1922.pdf , s.12, erişim tarihi : 22 Ocak 2019;McCombs, Maxmell.(2014). Setting The Agenda, 2nd Edition, Polity Press, s.24

$\left.{ }^{[17}\right]$. McCombs, Maxmell.(2014). Setting The Agenda, 2nd Edition, Polity Press, s.1

$\left.{ }^{18}\right]$. McCombs, Maxwell - Shaw, Donald L. -Weaver, David. (1977). Communication and Democracy, Routledge, New York, s.18

$\left[{ }^{19}\right]$. Agenda Setting: Reading on Media, Public Opinion, and Policymaking (Edited by David L.ProtessMaxmell McCombs)(1991). Lawrence Erlbaum Associates, s.ix

$\left.{ }^{20}\right]$. İlgili yazı için bkz. Rivers, William L. (1991). “ The Media as Shadow Government”, Agenda Setting : Reading on Media, Public Opinion, and Policymaking (Edited by David L.Protess-Maxwell McCombs), Lawrence Erlbaum Associates, s.153-160

$\left.{ }^{21}\right]$. İlgili yazı için bkz..Winter, James P- Eyal, Chaim H.(1991). “Agenda-Setting for the Civil Rights Issue”, Agenda Setting: Reading on Media, Public Opinion, and Policymaking (Edited by.Protess, Pritchard L - McCombs, Maxwell), Lawrence Erlbaum Associates , s.103 (101-117)

[22]. Martin, Michel. (1991). Communication et Médias de Masse, Presses de l'Université du Québec, Québec, s.87

$\left[{ }^{23}\right]$. Agenda Setting: Reading on Media, Public Opinion, and Policymaking (Edited by David L.ProtessMaxmell McCombs). (1991). Lawrence Erlbaum Associates, s.208

$\left[{ }^{24}\right]$. A.e.,s. 208

$\left[{ }^{25}\right]$. A.e.,s. 208

$\left[{ }^{26}\right]$. Turk, Judy VanSlyke. (1991). “Public Relations Influence on the News”. Public Relations' Agenda Setting: Reading on Media, Public Opinion, and Policymaking (Edited by David L.Protess- Maxmell McCombs). (1991). Lawrence Erlbaum Associates, s.211 
[27]. Gandy, Oscar H. (1982). "Beyond Agenda-Setting: Information Subsidies and Public Policy (Norwood, N.J.:Ablex Publishing Co.), s.14'den aktaran Turk, Judy VanSlyke .(1991). “Public Relations Influence on the News". Public Relations' Agenda Setting: Reading on Media, Public Opinion, and Policymaking (Edited by David L.Protess- Maxmell McCombs), (1991). Lawrence Erlbaum Associates, s.212

$\left[{ }^{28}\right]$. Amerikalıların halkla ilişki olarak tanımladığı "public relations" burada halkla ilişkilerden ziyade kamu ile yapılan "ikili ilişkiler” olarak tanımlanması gerekmektedir.

$\left.{ }^{29}\right]$. Agenda Setting: Reading on Media, Public Opinion, and Policymaking (Edited by David L.ProtessMaxmell McCombs). (1991). Lawrence Erlbaum Associates, s.149

$\left.{ }^{30}\right]$. Bkz. Şekil 1.1, Maxmell McCombs. (2014). Setting The Agenda, 2nd Edition, Polity Press, s.5

$\left.{ }^{[31}\right]$. Bkz. Şekil 3.1, Maxmell McCombs. (2014). Setting The Agenda, 2nd Edition, Polity Press, s.41

$\left[{ }^{32}\right]$. Bkz. Şekil 7.1. Maxmell McCombs. (2014). Setting The Agenda, 2nd Edition, Polity Press, s.112

$\left.{ }^{33}\right]$. Şekil 3'de çizimin orijinaline sadık kalarak Kamu Gündemi’nin Siyasi Gündemi etkilediğini sembolize etmesi tek yönlü bir ok ile gösterilmiştir. Ancak günümüzde Siyasi Gündem de Kamu Gündemini doğrudan etkileyebilmektedir.

$\left.{ }^{34}\right]$. Everett, M.Rogers- Dearing, James W. (1988). "Agenda-Setting Research: Where has It Been, Where Is It Going?, Communication Yearbook (11 January 1988), s.556 (555-594), https://goo.gl/4rzp3J , erişim tarihi : 28 Ocak 2019

$\left[{ }^{35}\right]$. A.e., s.556, https://goo.gl/4rzp3J , erişim tarihi : 28 Ocak 2019

$\left[{ }^{36}\right]$. A.e., s.557, https://goo.gl/4rzp3J , erişim tarihi : 28 Ocak 2019

$\left[{ }^{37}\right]$. A.e., s.557, https://goo.gl/4rzp3J , erişim tarihi : 28 Ocak 2019

$\left.{ }^{38}\right]$. Watchdog tabiri pejoratif anlamda görülse de, medya sahipleri ve çalışanları için sorumluluk ve kuvvet ifade eden İngilizce bir tanımlamadır.

$\left.{ }^{39}\right]$. Amerika Birleşik Devletleri’ndeki örnek sorgulama için bkz. "Dunbar, John. (2005). “Who is watching the watchdog?", The Future Resistance and Reform in the 21st Century of Media (Edited by McChesney, Robert W. - Newman, Russell- Scott, Ben), Seven Stories Press, New York, (May 2005), s.127-140

$\left[{ }^{40}\right]$.Pritchard, David - Sauvageau, Florian. (1999). Les Journalistes canadiens : Un portrait de fin de siècle, Les Presses de l'Université Laval, s.72

$\left.{ }^{41}\right]$.Anderson, C.W.- Downie Leonard JR- Schudson, Michael. (2016). The News Media : What Everyone Needs to Know, Oxford Univesity Press, s.68

$\left.{ }^{42}\right]$. A.e. ,s.68

$\left.{ }^{43}\right]$.Yüksel, Erkan. (2001). Medyanın Gündem Belirleme Gücü, Çizgi Kitapevi, Konya, s.29

$\left[{ }^{44}\right]$. All-news

$\left.{ }^{45}\right]$. McPhail, Thomas L.(2010). Global Communication : Theories, Stakeholders, and Trends, WileyBlackwell, Third Edition, Singapore, s.243 
${ }^{[46}$. Rus televizyon kanalı RT uluslararası boyutta, sadece Rusça, İngilizce, Arapça, Fransızca ve Almanca dillerinde ayrı ayrı yayın yapmaktadır.

$\left[{ }^{47}\right]$. Bu sayı kademeli olarak artmaktadır.

$\left.{ }^{48}\right]$. Union of Concerned Scientists. (2018). "UCS Satellite Database", https://www.ucsusa.org/nuclearweapons/space-weapons/satellite-database\#.XFmzdlUzYuU, erişim tarihi:05.02.2019; Ayrıca uyduların detaylı bilgileri ve ülke bazında inceleme için bkz. Union of Concerned Scientists, "UCS Satellite Database", https://s3.amazonaws.com/ucs-documents/nuclear-weapons/sat-database/1220-18-update/UCS_Satellite Database 12-1-2018.xlsx , erişim tarihi:05.02.2019

$\left[{ }^{49}\right]$. Geo uydular aynı zamanda "yer eş zamanlı yörünge" kabiliyetine sahip uydu olarak da tanımlanmaktadır.

$\left[{ }^{50}\right]$. Bu durum bu elit kişilerin, ilgili şirkete ait hisse senedi veya pay sahibi olmadığı veya olmayacağ anlamina gelmemelidir.

[51]. Şekil 5, Maslow'ın Hiyerarşi teorisinden ve Roskin'in Sistem Teorileri şemasından esinlenilmiştir. Bkz. Roskin, Michael G. - Cord, Robert L.- Medeiros, James A. \& Jones, Walter S.(2012). Political Science : An Introduction, Twelfth Edition, Pearson, Boston, s. 22

[52]. Şekil 6, Maslow'ın Hiyerarşi teorisinden ve Roskin ve diğerlerinin Sistem Teorileri şemasından esinlenilmiştir. Bkz. Roskin ve diğerleri, a.e., s.22

$\left.{ }^{53}\right]$. Şekil 7, Maslow'ın Hiyerarşi teorisinden ve Roskin ve diğerlerinin Sistem Teorileri şemasından esinlenilmiştir. Bkz. Roskin ve diğerleri, a.e., s.22

$\left.{ }^{54}\right]$. Bir metafor ile interneti büyük bir okyanus, internet üzerinde gezinti, yüzeysel veya derinlemesine araştırma ve bilgiye ulaşmak, iletişim kurmak vb işlevler için kullanılan tüm araçları ise okyanusu geçtiğimiz ve üzerinde sefer yaptığımız deniz ve hava araçlarına benzetebiliriz.

$\left.{ }^{55}\right]$. Augustine, Roslyn Satchel - Augustine, Jonathan C.(2012). "Religion, Race, and the Fourth Estate : Xenophobia in the Media Ten Years After 9/11", The Tennessee Journal of Race, Gender, \& Social Justice, Volume 1, Spring $2012 \quad$ Number $1 \quad$, s.8,10 (4-58) https://trace.tennessee.edu/cgi/viewcontent.cgi?article=1001\&context=rgsj, erişim tarihi 31 Aralık 2018 ; Dördüncü kuvvet çoğunlukla medya (basın) olarak tanımlandığı gibi, dinin dördüncü ve medyanın beşinci kuvvet olarak tanımlandığı tespitler de bulunmaktadır. Ancak, genel hâkim olan ve terminolojik olarak kabul gören medyanın dördüncü kuvvet olduğudur. ; Bkz. The Conversation. (2013). "Right to know: the 'nation', the 'people' and the Fourth Estate", (11 December 2013), https://theconversation.com/right-to-know-the-nation-the-people-and-the-fourth-estate-21253, erişim tarihi:20 Şubat 2019

$\left.{ }^{56}\right]$. Ignacio Ramonet 2003 yılından önceki son on beş yıllık dönemi eleştirmiştir. Bkz. Ramonet, Ignacio . (2003). "Le cinquième pouvoir", Le Monde diplomatique, (Octobre 2003), https://www.mondediplomatique.fr/2003/10/RAMONET/10395, erişim tarihi: 31 Aralık 2018

$\left.{ }^{[57}\right]$. Filmin orijinal ad1, "the Fifth Estate" dir.

$\left[{ }^{58}\right]$. Günümüzde tüm dünya ülkelerinin yer aldığı bu sanal evrende, özellikle kurucusu ve geliştiricisi olma sıfatıyla ağırlıklı olarak Amerika Birleşik Devletleri temelli bir hâkimiyet ve kontrol gücünün olduğu yadsınamaz bir gerçektir. Bu gerçek ile karşı karşıya kalınan ve bu kontrol ve hâkimiyet çatışmasının yarattığı diğer bir sorun, Çin ve Rusya gibi ülkelerin bu evren içinde internet bazlı kullandıkları tüm iletişim araç ve uygulamalarının serbestçe kullanabilme imkânlarından çok kendi siber güvenlikleri açısından tedirgin olmaları internet evrenine ilişkin ayrı tartışmaları da beraberinde getirmektedir. Bu hassasiyetin ülke ulusal güvenliğinde risk yaratması örneğin Rusya'yı kendi internet evrenini kurma çalışmalarına yönlendirmektedir. Rusya'nın girişimleri için bkz. Radio- 
Canada, "La Russie veut son propre Internet", 14 février 2019, https://ici.radiocanada.ca/premiere/emissions/medium-large/segments/chronique/106095/russie-veut-son-propreinternet-seraiocco, erişim tarihi: 14 Şubat 2019

$\left.{ }^{59}\right]$. Bloomberg, "TWTR:US , Twitter Inc", https://www.bloomberg.com/quote/TWTR:US

$\left[{ }^{60}\right]$. Forbes, "\#21 Twitter",https://www.forbes.com/companies/twitter/\#3769154122a3, erişim tarihi:20 Şubat 2019

[61]. Twitter ile aşağıda yer alan ve italik olarak gösterilen tüm bilgiler "Omnicore,"Twitter by the Numbers: Stats, Demographics \& Fun Facts: Twitter Statistics", https://www.omnicoreagency.com/twitter-statistics/, erişim tarihi:20 Şubat 2019” den alınmıştır.

$\left.{ }^{62}\right]$. Omnicore,"Twitter by the Numbers: Stats, Demographics \& Fun Facts: Twitter Statistics", https://www.omnicoreagency.com/twitter-statistics/ , erişim tarihi:20 Şubat 2019

$\left[{ }^{63}\right]$.Verill, A. Hyatt . (1922). The Home Radio: How to Make and Use It (New York, Harper \&Brothers), p.iii'den aktaran.Meinrath, Sascha D. (2005). “Wirelessing the World: the Battle Over (Community) Wireless Networks, The Future of Media : Resistance and Reform in the 21st Century ( Edited by Bill Moyers-Russell Newman-Ben Scott), Seven Stories Press, New York, s.228 (219-242)

[ ${ }^{64}$ ]. Forbes,"Top 100 Digital Companies", erişim tarihi:26 Şubat 2019

[65]. Citigroup 2014 yılında ise Instagram'ın piyasa değerini 35 milyar dolar olarak tespit etmişti. Oysa 2018 yllında 100 milyar dolarlık bir piyasa değerine ulaşmıştır. Bkz. Gelles, David. (2014). "Citigroup Says Instagram Is Worth \$35 Billion", New York, (19 December 2014), https://dealbook.nytimes.com/2014/12/19/citigroup-says-instagram-is-worth-35-billion/ , erişim tarihi: $26 \quad$ Şubat $2019 \quad$; $\quad$ Forbes, "Periscope", https://www.forbes.com/profile/periscope/\#39749abb6efe, erişim tarihi:26 Şubat 2019

[66]. 16 Nisan 2019 tarihinde ise, bu rakamlar, 41.264 tweet, 59.725 .097 takipçi 8 beğeni şeklinde güncellenebilir. Trump'ın 7 Mart 2019 tarihinde 9 olan beğeni sayıs1 16 Nisan 2019'da 8'e düşmüştür. Trump'ın hangi beğeniyi sildiği ise tespit edilememiştir.

[67]. Mueller raporu hakkındaki açıklamalar için bkz. France 24. (2019). "Mueller report summary says Trump campaign did not 'conspire or coordinate' with Russia", (24 March 2019), https://www.france24.com/en/20190324-Mueller-report-summary-trump-campaign-not-conspireRussia-2016-election ,erişim tarihi:31 Mart 2019; Bach, Natascha . (2019). "Collusion vs. Obstruction: Did the Mueller Report Really Exonerate Trump?",Fortune, (25 March 2019), http://fortune.com/2019/03/25/barr-mueller-report-summary-pdf/ ,erişim tarihi:31 Mart 2019

$\left[{ }^{68}\right]$.Baker, Peter - Fandos, Nicholas. (2018). "Prosecutors Effectively Accuse Trump of Defrauding Voters. What Does It Mean?", The New York Times, (8 December 2018), https://www.nytimes.com/2018/12/08/us/politics/trump-mueller-cohen-manafort.html ，erişim tarihi:25 Mart 2019

$\left[{ }^{69}\right] . J a n s e n$, Bart - Johnson, Kevin - Brook, Tom Vanden . (2019). "Special counsel Robert Mueller delivers report marking end of investigation into Trump's campaign, Russia",USA Today, (22 March 2019), https://www.usatoday.com/story/news/politics/2019/03/22/robert-mueller-report-presidenttrump-russia-election-investigation/2213214002/ , erişim tarihi:25 Mart 2019; Swaine, Jon Gambino, Lauren. (2019). "Mueller report: special counsel delivers findings of Trump-Russia inquiry", The Guardian, (22 March 2019), https://www.theguardian.com/usnews/2019/mar/22/mueller-report-trump-russia-investigation-completed-latest-news , erişim tarihi:25 Mart 2019 
$\left[{ }^{70}\right]$. Burland, Ross J . (2019) "The Robert S. Mueller report is a significant political victory for Trump", FXStreet, https://www.fxstreet.com/news/the-robert-s-mueller-report-is-a-significant-politicalvictory-for-trump-201903242210, erişim tarihi:25 Mart 2019

[71].Polantz, Katelyn- Murray, Sara- Shortell, David . (2019). "Mueller indicts Roger Stone, says he was coordinating with Trump officials about WikiLeaks' stolen emails", CNN, (25 January 2019), https://edition.cnn.com/2019/01/25/politics/roger-stone-arrested/index.html , erişim tarihi: 25 Mart 2019; McCarthy, Tom. (2019). "Roger Stone's arrest may renew threat of impeachment for Trump", The Guardian, (25 January 2019), https://www.theguardian.com/us-news/2019/jan/25/roger-stonearrest-trump-impeachment-what-news-means, erişim tarihi:25 Mart 2019

$\left[{ }^{72}\right]$. Polantz, Katelyn - Berman, Dan- Cohen, Marshall- Stark, Liz . (2018). "Paul Manafort found guilty on eight counts", CNN, (22 August 2018), https://edition.cnn.com/2018/08/21/politics/paulmanafort-trial-jury/index.html ,erişim tarihi:25 Mart 2019

$\left.{ }^{73}\right]$.Crilly, Rob. (2018). "Siege politics as Democrats say Donald Trump could face prison over hush payments", The Telegraph, $\quad$ (9 https://www.telegraph.co.uk/news/2018/12/09/siege-politics-democrats-discuss-impeachmentdonald-trump-hush/, erişim tarihi:25 Mart 2019 ; The Bloomberg, "It's been 3 days since Trump last tweeted about the markets and the economy...", 23 March 2019, https://www.bloomberg.com/features/trump-tweets-market/ ,erişim tarihi:25 Mart 2019 ; Palazzolo, Joe . (2018). "Cohen Describes Trump's Involvement in Hush-Money Payments", The Wall Street Journal,(14 December 2018), https://www.wsj.com/articles/michael-cohen-says-trump-directed-meto-become-involved-in-hush-money-payments-to-two-women-11544790717, erişim tarihi:25 Mart 2019

$\left[{ }^{74}\right]$. Bkz. Ingram, Mathew. (2017) "Trump Plans to Keep Tweeting Regardless of the Media's Response", Fortune, (6 June 2017), http://fortune.com/2017/06/06/trump-twitter-media/ , erişim tarihi:25 Mart 2019

$\left.{ }^{75}\right]$. Bloomberg, (2019). "It's been 3 days since Trump last tweeted about the markets and the economy...", (23 March 2019), https://www.bloomberg.com/features/trump-tweets-market/ , erişim tarihi:25 Mart 2019

$\left.{ }^{76}\right]$. Morris, Chris. (2017). "Trump Tweets-As Read By Gollum", Fortune, (July 12, 2017), http://fortune.com/2017/07/12/trump-tweets-gollum-colbert/ , erişim tarihi:11 Mart 2019

${ }^{77}$ Lisa Marie Segarra, "This Is How Many People Actually Read Trump's Tweets", May 17, 2018, http://fortune.com/2018/05/17/donald-trump-twitter-tweets/ , erişim tarihi: 11 Mart 2019

$\left[{ }^{78}\right]$. Örneğin Tablo 13'de ve kaynakçalarda linkleri belirtilen haberler.

$\left.{ }^{79}\right]$. Joshua Brisco adlı lisans öğrencisi tarafından yapılan 140 kelimede gündem belirleme konulu poster için bkz. Brisco, Joshua. (2017). "Setting the Agenda in 140 Characters: Agenda Setting Theory and Donald Trump's Twitter", Wesleyan-Holiness Digital Library, (6 April 2017), https://www.whdl.org/setting-agenda-140-characters-agenda-setting-theory-and-donald-trumpstwitter, erişim tarihi:17.03.2019

$\left[{ }^{80}\right]$.Borna, Jeffery A. - Myersa, David H. - Clarkb, William J. (2017). "Trump tweets and the efficient Market

Hypothesis" Algorithmic Finance, 6 (2017) 103-109, s.103, IOS Press, https://content.iospress.com/download/algorithmic-finance/af211?id=algorithmicfinance\%2Faf211, erişim tarihi:31 Mart 2019 
$\left.{ }^{81}\right]$.Borna, Jeffery A. - Myersa, David H. - Clarkb, William J. (2017). "Trump tweets and the efficient Market

Hypothesis" Algorithmic Finance, 6 (2017) 103-109, s.103, IOS Press, https://content.iospress.com/download/algorithmic-finance/af211?id=algorithmicfinance\%2Faf211, erişim tarihi:31 Mart 2019

$\left[{ }^{82}\right]$. Colonescu, Constantin . (2018). "The Effects of Donald Trump's Tweets on US Financial and Foreign Exchange Markets",Athens Journal of Business \& Economics Volume 4, Issue 4, (October 2018), s.375 (375-388), https://www.athensjournals.gr/business/2018-4-4-2-Colonescu.pdf, erişim tarihi:17.03.2019

[ $\left.{ }^{83}\right]$. Durden, Tyler . (2017). "Largest Retail FX Broker FXCM Banned By CFTC, Fined $\$ 7$ Million For Taking Positions Against Clients", (02.06.2017), https://www.zerohedge.com/news/2017-0206/largest-retail-fx-broker-fxcm-banned-cftc-fined-7-million-taking-positions-against-c , erişim tarihi: 19 Mart.2019

$\left[{ }^{84}\right]$. Trump'ın 2 Mart 2018 tarihinde yayınladığı tweetin orijinali için bkz. Twitter, Donal J. Trump, 2 March 2018, https://twitter.com/realdonaldtrump/status/969525362580484098, erişim tarihi :19 Mart 2019 Bu tweetin İngilizcesi "When a country (USA) is losing many billions of dollars on trade with virtually every country it does business with, trade wars are good, and easy to win. Example, when we are down $\$ 100$ billion with a certain country and they get cute, don't trade anymore-we win big. It's easy!" şeklindedir.

[ $\left.{ }^{85}\right]$. Örnek haber için bkz. Carr, Flora. (2018). "Donald Trump Says Trade Wars Are 'Good and Easy to Win'", Time, (2 March 2018), http://time.com/5182460/donald-trump-trade-wars-tweets/, erişim tarihi:19 Mart 2019

[86]. FXCM. (2018). "How Does President Trump's Twitter Use Impact Forex, Markets And Stocks?", (27 November 2018), https://www.fxcm.com/uk/insights/t/usa/ ;

https://www.fxcm.com/uk/insights/president-trumps-twitter-impact-forex-markets-stocks/ ， erişim tarihi:19 Mart 2019

$\left[{ }^{87}\right]$. McCormick, Liz - Nguyen, Lananh.(2018). "The Yen Emerges as the Currency-Market Winner From Trade Tensions", Bloomberg, (2 March 2018), https://www.bloomberg.com/news/articles/2018-03-02/yen-emerging-as-currency-market-winneras-trade-tensions-mount, erişim tarihi:21 Mart 2019

[ $\left.{ }^{88}\right]$. Gibson, Kate. (2018). "Trump says China, EU "manipulating their currencies" -- and U.S. dollar hit", CBS News, (20 July 2018), https://www.cbsnews.com/news/trump-accuses-china-eu-ofcurrency-manipulation-and-dollar-weakens/, erişim tarihi:24 Mart 2019

[ $\left.{ }^{89}\right]$ Twitter, "Donald J. Trump", 20 July 2018, https://twitter.com/realdonaldtrump/status/1020287981020729344, erişim tarihi:24 Mart 2019; Bu tweetin İngilizcesi için bkz. "China, the European Union and others have been manipulating their currencies and interest rates lower, while the U.S. is raising rates while the dollars gets stronger and stronger with each passing day - taking away our big competitive edge. As usual, not a level playing field..."

$\left[{ }^{90}\right]$. Chan, Szu Ping.(2018). "US trade war would make world 'poorer and more dangerous'", BBC, $(9$ October 2018), https://www.bbc.com/news/business-45789669, erişim tarihi:1 Nisan 2019

$\left[{ }^{91}\right]$ Twitter, $\quad$ "Donald $\quad$ J. Trump", 9 June 2018, https://twitter.com/realDonaldTrump/status/1005586152076689408, erişim tarihi : 16 Nisan 2019; Tweetin İngilizcesi “Based on Justin's false statements at his news conference, and the fact that 
Canada is charging massive Tariffs to our U.S. farmers, workers and companies, I have instructed our U.S. Reps not to endorse the Communique as we look at Tariffs on automobiles flooding the U.S. Market!” şeklindedir.

$\left.{ }^{92}\right]$. Hoppe, Mattias. (2018). "Cutting through the Noise: Trump, Trade and Twitter", Advisor Persepectives, (2 August 2018), https://beta.advisorperspectives.com/commentaries/2018/08/02/cutting-through-the-noise-trumptrade-and-twitter?channel=Capital\%20Growth , erişim tarihi: 16 Nisan 2019

$\left[{ }^{93}\right]$. A.e.

$\left[{ }^{94}\right]$. Twitter, "Trump J.Donald", 20 April 2018, https://goo.gl/8UH4x1 , erişim tarihi:22 Mart 2019; Bu tweetin İngilizce orijinali "Looks like OPEC is at it again. With record amounts of Oil all over the place, including the fully loaded ships at sea, Oil prices are artificially Very High! No good and will not be accepted!" şeklinde 20 Nisan 2018 tarihinde yayınlanmıştır; Örnek kapsamında verdiğimiz bu tweet "FXCM, "How Does President Trump's Twitter Use Impact Forex, Markets And Stocks?", 27 November 2018, https://www.fxcm.com/uk/insights/t/usa/ ;

https://www.fxcm.com/uk/insights/president-trumps-twitter-impact-forex-markets-stocks/ ,erişim tarihi: 21 Mart 2019" yaptığı piyasa analizde yer alan tweet örneğinden ve ilgili uluslararası çıkan haber başlıklarından çıkarılmıştır.

$\left.{ }^{95}\right]$. Bkz. DiChristopher, Tom. (2018). "US crude ticks up 9 cents, settling at $\$ 68.38$, as market shakes off Trump's attack on OPEC", CNBC, (20 April 2018), https://www.cnbc.com/2018/04/20/oil-fallsafter-trump-goes-after-opec-in-a-tweet.html ,erişim tarihi:22 Mart 2019

$\left[{ }^{96}\right]$ Twitter, $\quad$ "Donal J.Trump", $30 \quad$ June 2018 , https://twitter.com/realdonaldtrump/status/1013023608040513537, erişim tarihi: 1 Nisan 2019; Bu tweetin İngilizcesi "Just spoke to King Salman of Saudi Arabia and explained to him that, because of the turmoil \& disfunction in Iran and Venezuela, I am asking that Saudi Arabia increase oil production, maybe up to 2,000,000 barrels, to make up the difference...Prices to high! He has agreed!” şeklindedir.

$\left[{ }^{97}\right]$. Saefong, Myra P. - Kollmeyer, Barbara. (2018). "U.S. oil prices slip, but global prices sink as traders fret over potential for higher output", marketwatch, (2 July 2018), https://www.marketwatch.com/story/oil-prices-slide-after-trump-tweet-hints-at-bigger-productionrise-from-saudis-2018-07-02, erişim tarihi:1 Nisan 2019

$\left[{ }^{98}\right]$.Decambre, Mark . (2018). "Trump says Saudi Arabia agreed to raise oil output by 'maybe up to' 2 million barrels a day", marketwatch, (30 June 2018), https://www.marketwatch.com/story/trumpsays-saudi-arabia-agreed-to-raise-oil-output-by-maybe-up-to-2-million-barrels-a-day-2018-06-30, erișim tarihi: 1 Nisan 2019

$\left[{ }^{99}\right]$ Twitter,"Donald $\quad$ J.Trump", $20 \quad$ September 2018 , https://twitter.com/realdonaldtrump/status/1042733544466989057 ,erişim tarihi: 25 Mart 2019; Bu tweetin İngilizcesi "We protect the countries of the Middle East, they would not be safe for very long without us, and yet they continue to push for higher and higher oil prices! We will remember. The OPEC monopoly must get prices down now!” şeklindedir.

$\left.{ }^{100}\right]$. Denning, Liam . (2018). "Trump's OPEC Tweets Mix Fear and Delusion", Bloomberg, (20 september 2018), https://www.bloomberg.com/opinion/articles/2018-09-20/trump-tweets-on-opecoil-prices-mix-fear-and-delusion , erişim tarihi:25 Mart 2019

[101]. Twitter, "Donald J. Trump", $25 \quad$ February 2019, https://twitter.com/realdonaldtrump/status/1100002139282309121, erişim tarihi: 25 Mart 2019; Bu 
tweetin İngilizcesi için bkz "Oil prices getting too high. OPEC, please relax and take it easy. World cannot take a price hike - fragile!"

$\left.{ }^{102}\right]$. DiChristopher, Tom - Haigh, Marilyn. (2019). "Oil sinks more than 3 percent after Trump tells OPEC prices are too high", CNBC, (25 February 2019), https://www.cnbc.com/2019/02/25/oil-fallsafter-trump-says-prices-are-too-high-and-tells-opec-the-world-cannot-take-a-price-hike.html ,erişim tarihi:25 Mart 2019; Vincent, Nyandabeh Ella. (2019). "Oil prices fall 3\% after Trump tweets about high prices", IG, (26 Februaary 2019), https://www.ig.com/en/news-and-tradeideas/commodities-news/oil-prices-fall-3--after-trump-tweets-about-high-prices-190225 ,erişim tarihi:25 Mart 2019

$\left.{ }^{103}\right]$. GoldPrice, , https://goldprice.org/gold-price-today/2019-02-25 ,erişim tarihi:25 Mart 2019

$\left.{ }^{104}\right]$. GoldPrice, , https://goldprice.org/gold-price-today/2019-02-26 ,erişim tarihi:25 Mart 2019

[105]. Okun, Eli . (2019). "A threat in Trump's back pocket: Shaking up the global oil industry", Politico, (22 April 2019), https://www.politico.com/story/2019/04/22/trump-oil-prices-opec-legislation$\underline{1273467}$, erişim tarihi:29 Nisan 2019

$\left.{ }^{[06}\right]$. Wingfield, Brian - Dodge, Samuel - Sam, Cedric.(2019). "The Saudi Effect: Kingdom

Makes OPEC+ Oil Pact Work", Bloomberg, (16 April 2019), https://www.bloomberg.com/graphics/opec-production-targets/ , erişim tarihi: 29 Nisan 2019

[107]. Sputniknews (2019). "ABD Başkanı Donald Trump'ın "OPEC'e petrol fiyatlarını düşürme çağrısı yaptım" açıklamasının ardından petrol fiyatları yüzde 2.5 azaldı.", (26 Nisan 2019), https://tr.sputniknews.com/ekonomi/201904261038878793-trump-opece-petrol-fiyatlarinidusurme-cagrisi-yaptim/,erişim tarihi:29 Nisan 2019

$\left.{ }^{108}\right]$ Twitter, $\quad$ "Donald J.Trump", 22 April 2019 , https://twitter.com/realdonaldtrump/status/1120320642686038016, erişim tarihi : 29 Nisan 2019; Bu tweetin İngilzcesi "Saudi Arabia and others in OPEC will more than make up the Oil Flow difference in our now Full Sanctions on Iranian Oil. Iran is being given VERY BAD advice by @JohnKerry and people who helped him lead the U.S. into the very bad Iran Nuclear Deal. Big violation of Logan Act?"şeklindedir.

$\left.{ }^{109}\right]$. Ancak bu başlatılan Twitter-diplomasisi aynı zamanda tepkilere de neden olmaktadır. Örneğin, farklı bir konu olan Trump'ın Suriye konusunda Rusya’yı hedef alan tweetleri karşısında, Kremlin, ABD başkanı Trump'ın Twitter diplomasisi ile muhatap olmayacaklarını beyan etmişlerdir. Bkz. Aljazeera,"Kremlin to Trump: We don't engage in Twitter diplomacy", 12 April 2018, https://www.aljazeera.com/news/2018/04/kremlin-trump-dont-engage-twitter-diplomacy180412074128245.html ,erișim tarihi:23 Mart 2019

[110]. Twitter, " Donald J. Trump", 6 December 2017, https://twitter.com/realdonaldtrump/status/938517073508163584, erişim tarihi:23 Mart 2019; Bu tweetin İngilizcesi "I have determined that it is time to officially recognize Jerusalem as the capital of Israel. I am also directing the State Department to begin preparation to move the American Embassy from Tel Aviv to Jerusalem..."şeklindedir.

[111]. Jerusalem Embassy Act of 1995, Public Law 104-45- Nov.8, 1995, https://www.congress.gov/104/plaws/publ45/PLAW-104publ45.pdf, erişim tarihi:23 Mart 2019

$\left.{ }^{112}\right]$. Bu konu ile ilgili analizler için bkz. Bump, Philip.(2017). "In 1995, Congress reached a compromise on the issue of Jerusalem. Trump is poised to end it.", The Washington Post, (6 December 2017), https://www.washingtonpost.com/news/politics/wp/2017/12/06/in-1995- 
congress-reached-a-compromise-on-the-issue-of-jerusalem-trump-is-poised-to-endit/?noredirect=on\&utm term=.f6e50041a19b , erişim tarihi:23 Mart 2019

$\left.{ }^{113}\right]$. Twitter, $\quad$ "Chuck Grassley", 6 December https://twitter.com/ChuckGrassley/status/938514996207767552 , erişim tarihi:23 Mart 2019; Bu tweetin İngilizcesi "Jerusalem Embassy Act of ' 95 (Senate vote 93-5 \& I voted for it) states embassy should be in Jerusalem by 5/31/99. For $18 \mathrm{yrs}$, Rep + Dem presidents waived. Congrats Pres Trump for making this move. Amen!!!” şeklindedir.

[114]. İlgili haberler için bkz. Harding, Luke . (2016). "What we know about Russia's interference in the US election", The Guardian, (11 December 2016), https://www.theguardian.com/usnews/2016/dec/16/qa-russian-hackers-vladimir-putin-donald-trump-us-presidential-election , erişim tarihi:23 Mart 2019

[115]. İlgili haber için bkz. Landler, Mark.(2017). "Trump Recognizes Jerusalem as Israel's Capital and Orders U.S. Embassy to Move", The New York Times, (6 December 2017), https://www.nytimes.com/2017/12/06/world/middleeast/trump-jerusalem-israel-capital.html , erișim tarihi:23 Mart 2019

[116]. The White House, "Statement by President Trump on Jerusalem", 6 December 2017, https://www.whitehouse.gov/briefings-statements/statement-president-trump-jerusalem/ ， erişim tarihi: 23 Mart 2019

[117]. Twitter, $\quad$ "Donald $\quad$ J. $\quad$ Trump", $14 \quad$ May 2018, https://twitter.com/realdonaldtrump/status/995980604016611329 , erişim tarihi:23 Mart 2019; Bu tweetin İngilizcesi için bkz. "U.S. Embassy opening in Jerusalem will be covered live on @FoxNews \&@FoxBusiness. Lead up to 9:00 A.M. (eastern) event has already begun. A great day for Israel!”

$\left.{ }^{118}\right]$. Tablo 13 'e ilişkin kaynakların her birisi dipnot olarak ilgili tablonun içinde belirtilmiştir.

$\left.{ }^{119}\right]$. Ingram, Mathew . (2017). "Trump Plans to Keep Tweeting Regardless of the Media's Response", Fortune, (6 June 2017), http://fortune.com/2017/06/06/trump-twitter-media/ , erişim tarihi:25 Mart 2019

$\left.{ }^{120}\right]$. Jackson, David - Shesgreen, Deirdre ( 2018). "President Trump's ambitious agenda: 7 things to watch in 2018",USA TODAY, (1 January 2018), https://www.usatoday.com/story/news/politics/2018/01/01/president-trumps-ambitious-agenda-7things-watch-2018/944741001/ , erişim tarihi:24 Mart 2019

$\left.{ }^{121}\right]$.Carr, Flora. (2018). "Donald Trump Says Trade Wars Are 'Good and Easy to Win'", Time, (2 March 2018), http://time.com/5182460/donald-trump-trade-wars-tweets/ , erişim tarihi:23 Mart 2019

$\left.{ }^{122}\right]$.Timberg, Craig - Heath, Thomas - Romm, Tony. (2018). "How Washington is undermining the stock market's highest-flying sector", The Washington Post, (2 April 2018) , https://www.washingtonpost.com/business/economy/fresh-shockwaves-hit-us-markets-after-trumptweets-china-steps-up-trade-war/2018/04/02/1f3beebe-3678-11e8-9c0a85d477d9a226_story.html?noredirect=on\&utm_term=.adcedfbcfeba , erişim tarihi: 1 Nisan 2019

$\left.{ }^{123}\right]$. DiChristopher, Tom . ( 2018). "US crude ticks up 9 cents, settling at $\$ 68.38$, as market shakes off Trump's attack on OPEC", CNBC, (20 April 2018), https://www.cnbc.com/2018/04/20/oil-fallsafter-trump-goes-after-opec-in-a-tweet.html ,erişim tarihi:24 Mart 2019

$\left.{ }^{124}\right]$. Walker, Andrew. (2018). "G7: Fact checking Trump's tweets about trade", BBC, 11 June 2018, https://www.bbc.com/news/world-44438908, erişim tarihi: 16 Nisan 2019 
[125]. Decambre, Mark . (2018). "Trump says Saudi Arabia agreed to raise oil output by 'maybe up to' 2 million barrels a day", marketwatch, (30 June 2018), https://www.marketwatch.com/story/trumpsays-saudi-arabia-agreed-to-raise-oil-output-by-maybe-up-to-2-million-barrels-a-day-2018-06-30 , erişim tarihi: 1 Nisan 2019

$\left.{ }^{126}\right]$.Saefong, Myra P.- Kollmeyer, Barbara/ (2018). "U.S. oil prices slip, but global prices sink as traders fret over potential for higher output", marketwatch, (2 July 2018), https://www.marketwatch.com/story/oil-prices-slide-after-trump-tweet-hints-at-bigger-productionrise-from-saudis-2018-07-02 , erişim tarihi:1 Nisan 2019

$\left.{ }^{127}\right]$. Sergie, Mohammed (2018). "Tehran Taunts Trump, Telling Him His Tweets Drive Up Oil Prices", Bloomberg, (5 July 2018), https://www.bloomberg.com/news/articles/2018-07-05/iran-says-trump-

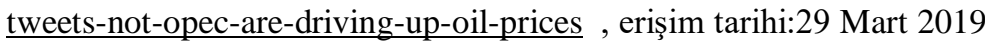

$\left[{ }^{128}\right]$. The Guardian. (2018). "Markets rattled as Trump escalates China trade war with tariffs on \$200bn of imports -as it happened", (11 July 2018), https://www.theguardian.com/business/live/2018/jul/11/markets-rattled-trump-escalates-chinatrade-war-200bn-new-tariffs-business-live , erişim tarihi:1 Nisan 2019

$\left.{ }^{129}\right]$. Gibson, Kate .(2018). "Trump says China, EU "manipulating their currencies" -- and U.S. dollar hit", CBS News, (20 July 2018), https://www.cbsnews.com/news/trump-accuses-china-eu-ofcurrency-manipulation-and-dollar-weakens/, erişim tarihi:24 Mart 2019

$\left.{ }^{130}\right]$. Denning, Liam. (2018). "Trump's OPEC Tweets Mix Fear and Delusion", Bloomberg, (20 September 2018), https://www.bloomberg.com/opinion/articles/2018-09-20/trump-tweets-on-opecoil-prices-mix-fear-and-delusion , erişim tarihi:25 Mart 2019

$\left({ }^{131}\right)$.Chan, Szu Ping. ( 2018). "US trade war would make world 'poorer and more dangerous'", BBC, (9 October 2018), https://www.bbc.com/news/business-45789669 , erişim tarihi:1 Nisan 2019

$\left.{ }^{132}\right]$. Gandel, Stephen. (2018)/ "Trump Is Now Bad for the Stock Market", Bloomberg, (26 October 2018), https://www.bloomberg.com/opinion/articles/2018-10-26/trump-is-bad-for-the-stock-market , erişim tarihi:1 Nisan 2019

$\left.{ }^{133}\right]$. Skrill. (2018). "Investing in the USD: How Trump affects the dollar's strength", 6 November 2018, https://www.skrill.com/skrill-news/forex/trump-dollar-strength/ , erişim tarihi:24 Mart 2019

$\left[{ }^{134}\right]$.Withers, Paul. (2018). "Trump MOCKS Saudi Arabia in brutal tweet and declares 'THANKS' for driving down oil prices", Express, (21 November 2018), https://www.express.co.uk/news/world/1048383/Donald-Trump-Saudi-Arabia-twitter-oil-prices , erişim tarihi:31 Mart 2109

[135]. FXCM. (2018). "How Does President Trump's Twitter Use Impact Forex, Markets And Stocks?", 27 November 2018, https://www.fxcm.com/uk/insights/t/usa/ ;

https://www.fxcm.com/uk/insights/president-trumps-twitter-impact-forex-markets-stocks/ ， erişim tarihi:23 Mart 2019

$\left.{ }^{136}\right]$. Baker, Peter - Fandos, Nicholas .(2018) "Prosecutors Effectively Accuse Trump of Defrauding Voters. What Does It Mean?", The New York Times, (8 December 2018), https://www.nytimes.com/2018/12/08/us/politics/trump-mueller-cohen-manafort.html ，erişim tarihi:25 Mart 2019 
[137]. Crilly, Rob. (2018). "Siege politics as Democrats say Donald Trump could face prison over hush payments", The Telegraph, $\quad$ (9 december https://www.telegraph.co.uk/news/2018/12/09/siege-politics-democrats-discuss-impeachmentdonald-trump-hush/, erişim tarihi:25 Mart 2019

$\left.{ }^{138}\right]$. Palazzolo, Joe. (2018). "Cohen Describes Trump's Involvement in Hush-Money Payments", The Wall Street Journal, (14 December 2018), https://www.wsj.com/articles/michael-cohen-says-trumpdirected-me-to-become-involved-in-hush-money-payments-to-two-women-11544790717 , erişim tarihi:25 Mart 2019

$\left.{ }^{139}\right]$. Valliere, Greg .(2018). "Trump's erratic behavior was background noise for markets. Not anymore", CNN, (21 December 2018), https://edition.cnn.com/2018/12/21/perspectives/stockmarket-fed-donald-trump/index.html, erişim tarihi:1 Nisan 2019

$\left[{ }^{140}\right]$. Drezner, Daniel W. .(2019). "Is Donald Trump losing his agenda-setting power?", (7 January 2019), https://www.washingtonpost.com/outlook/2019/01/07/is-donald-trump-losing-his-agendasetting-power/?noredirect=on\&utm_term=.c70e8e7fc30e , erişim tarihi:24 Mart 2019; Drezner, Daniel W. (2019). "Is Donald Trump losing his agenda-setting power?", (7 January 2019), https://fletcher.tufts.edu/news-events/news/donald-trump-losing-his-agenda-setting-power , erişim tarihi:24 Mart 2019

$\left.{ }^{141}\right]$. DiChristopher, Tom - Haigh, Marilyn. (2019). "Oil sinks more than 3 percent after Trump tells OPEC prices are too high", CNBC, (25 February 2019), https://www.cnbc.com/2019/02/25/oil-fallsafter-trump-says-prices-are-too-high-and-tells-opec-the-world-cannot-take-a-price-hike.html ,erişim tarihi:25 Mart 2019

$\left.{ }^{142}\right]$.Vincent, Nyandabeh Ella. (2019). "Oil prices fall 3\% after Trump tweets about high prices", IG, (26 February 2019), https://www.ig.com/en/news-and-trade-ideas/commodities-news/oil-pricesfall-3--after-trump-tweets-about-high-prices-190225 ,erişim tarihi:25 Mart 2019

[143].Okun, Eli. (2019). "A threat in Trump's back pocket: Shaking up the global oil industry", Politico, (22 April 2019), https://www.politico.com/story/2019/04/22/trump-oil-prices-opec-legislation$\underline{1273467}$, erişim tarihi:29 Nisan 2019

$\left.{ }^{144}\right]$ Jerusalem Embassy Act of 1995, Public Law 104-45-Nov.8, 1995, https://www.congress.gov/104/plaws/publ45/PLAW-104publ45.pdf , erişim tarihi:16 Nisan 2019

$\left.{ }^{145}\right]$. Bkz. White House, "Statement by President Trump on Jerusalem", 6 December 2017, https://www.whitehouse.gov/briefings-statements/statement-president-trump-jerusalem/ ,erişim tarihi: 16 Nisan 2019

$\left.{ }^{146}\right]$. United Nations, Security Council, " $\quad$ S/PV.2329, 20 January 1982", 2329th Meeting Held in New York on Wednesday, 20 January 1982, at 4 p.m., https://unispal.un.org/DPA/DPR/unispal.nsf/0/906E017E71607D778525737E004F33AA ， erişim tarihi:16 Nisan 2019

$\left.{ }^{147}\right]$. United Nations, $\quad$ "Resolution $497 \quad(1981) ", \quad 17$ December 1981, https://unispal.un.org/DPA/DPR/unispal.nsf/0/73D6B4C70D1A92B7852560DF0064F101 , erişim tarihi: 16 Nisan 2019

$\left.{ }^{148}\right]$. Twitter, " $\quad$ Donald J. Trump", 21 march 2019, https://twitter.com/realdonaldtrump/status/1108772952814899200, erişim tarihi:16 Nisan 2019; Tweetin İngilizcesi “After 52 years it is time for the United States to fully recognize Israel's Sovereignty over the Golan Heights, which is of critical strategic and security importance to the State of Israel and Regional Stability!"şeklindedir. 

[149]. Twitter, "Donald J.Trump", $25 \quad$ March 2019 , https://twitter.com/realdonaldtrump/status/1110242521400123394 , erişim tarihi:16 Nisan 2019; Tweetin İngilizcesi “Today, it was my great honor to welcome Prime Minister@Netanyahu of Israel back to the@WhiteHouse where I signed a Presidential Proclamation recognizing Israel's sovereignty over the Golan Heights. Read more: https://www.whitehouse.gov/presidential- actions/proclamation-recognizing-golan-heights-part-state-israel/ ...” şeklindedir.

$\left.{ }^{150}\right]$ Twitter, $\quad$ "Donald J.Trump", $26 \quad$ March 2019 , https://twitter.com/realdonaldtrump/status/1110681613359345664; Tweetin İngilizcesi "Proclamation on Recognizing the Golan Heights as Part of the State of Israel, https://www.whitehouse.gov/presidential-actions/proclamation-recognizing-golan-heights-partstate-israel/ ..." şeklindedir.

$\left.{ }^{151}\right]$. Bkz. Donald J.Trump, "Proclamation on Recognizing the Golan Heights as Part of the State of Israel", White House, 25 March 2019, https://www.whitehouse.gov/presidentialactions/proclamation-recognizing-golan-heights-part-state-israel// ,erişim tarihi:16 Nisan 2019

$\left.{ }^{152}\right]$. A.e

$\left.{ }^{153}\right]$. Taylor, Adam. (2019). "No president has recognized Israel's control of the Golan Heights. Trump changed that with a tweet.", The Washington Post, (22 march 2019), https://www.washingtonpost.com/world/2019/03/22/no-president-has-recognized-israels-controlgolan-heights-trump-changed-that-with-tweet/?noredirect=on\&utm term=.4a1c90ec8c35, erişim tarihi:16 Nisan 2019 